\title{
Origins of The Santa Maria And Vandenberg Coastal Dune Sheets ( 100-0 ka) Under Changing Sea Levels, Shoreline Orientations and Wave Directions: Long-Term Records of Coastal Sand Supply in South-Central California, USA
}

\author{
Curt D. Peterson ${ }^{1}$, Christopher Ryan ${ }^{2}$, Jack Meyer ${ }^{3}$, David Price ${ }^{4} \&$ Steve W. Hostetler ${ }^{5}$ \\ ${ }^{1}$ Portland State University, Portland, Oregon, USA \\ ${ }^{2}$ Vandenberg Air Force Base, Vandenberg AFB, California, USA \\ ${ }^{3}$ Far Western Anthropological Research Group, Davis, California, USA \\ ${ }^{4}$ Wollongong University, Wollongong, New South Wales, 2522, Australia \\ ${ }^{5}$ United States Geological Survey, Corvallis, Oregon, USA \\ Correspondence: Curt Peterson, Geology Department, Portland State University, Portland, OR., 97140, USA. Tel: \\ 1-503-730-9266. E-mail: curt.d.peterson@gmail.com
}

Received: December 2, 2017

doi:10.5539/jgg.v10n1p33
Accepted: December 12, 2017 Online Published: December 25, 2017

URL: http://dx.doi.org/10.5539/jgg.v10n1p33

The research is financed by the United States Air Force, Vandenberg Air Force Base, California.

\begin{abstract}
Two large coastal dune sheets, including the Santa Maria dune sheet and Vandenberg dune sheet, have been analyzed for late-Quaternary distributions, ages and volumes of dune sand deposition. Six new thermoluminescence (TL) ages establish the age range of dune sand deposition from $>106 \pm 21 \mathrm{ka}$ to $<4.1 \mathrm{ka}$ in the study area. Seven late-Pleistocene TL and ${ }^{14} \mathrm{C}$ dated mid-depth samples ( $\leq 30 \mathrm{~m}$ depth subsurface), yield a mean of $33 \mathrm{ka}$ for the late-Pleistocene dune deposits. Both TL and ${ }^{14} \mathrm{C}$ dated Holocene dune deposits establish a transition from weathered middle-Holocene dune deposits to unweathered latest-Holocene dune deposits after 4 ka. Marine sand supply to the large dune sheets occurred by 1) cross-shelf eolian transport during late-Pleistocene marine low-stands $(70-13 \mathrm{ka}), 2)$ shoreward wave transport during slowing of the Holocene marine transgression (9-5 ka), and 3) longshore littoral transport during the latest-Holocene marine high-sand (3.5-0 ka). Measured and dated dune deposit sections ( $\mathrm{n}=66$, ranging from 2 to $60 \mathrm{~m}$ depth) demonstrate substantial differences in preserved sand volumes between the two adjacent dune sheets, Santa Maria ( $\left.2,300 \times 10^{6} \mathrm{~m}^{3}\right)$ and Vandenberg $\left(\sim 430 \times 10^{6} \mathrm{~m}^{3}\right)$. Asymmetric distributions of dune deposit volumes between and within the dune sheets show that long-term sand supply was locally controlled by paleo-shoreline orientations relative to corresponding deep-water wave propagation directions $\left(260-290^{\circ} \mathrm{TN}\right)$ from the North Pacific Low Pressure Area. Recently declining sand supplies and/or -trapping efficiencies in the dune sheet littoral subcells led to ongoing shoreline retreat $(\geq 200 \mathrm{~m})$ and under-cutting of late- Holocene eolian sand ramps at the south ends of the Santa Maria and Vandenberg dune sheets. The termination of transgressive cross-shelf sand supply and locally variable longshore retention of littoral sand confirm previously reported framework models of regional coastal sand supply. Such models help to identify shorelines that are most susceptible to future beach erosion from predicted sea level rise following ongoing global warming.
\end{abstract}

Keywords: Quaternary, coastal dunes, continental shelf, paleo-sea level, paleo-shoreline, paleo-wave climate, coastal sand supply

\section{Introduction}

The Santa Maria and Vandenberg dune sheets represent two key localities within the larger Central West Coast of North America region (Figure 1) that merit study for paleo-sea level and paleo-wave climate forcing of coastal sand supply in late Quaternary time. The two dune sheets are nearly adjacent to one another, being separated by the fault-block Point Sal/Casmalia Hills, and are of similar along-coast length $(\sim 25 \mathrm{~km})$. They differ 
substantially, however, in maximum landward width: Santa Maria $(\sim 15 \mathrm{~km})$ and Vandenberg $(\sim 7 \mathrm{~km})$. Other coastal dune sheets within the larger study region, extending $\sim 1000 \mathrm{~km}$ both north and south of the Santa Maria-Vandenberg study area (Cooper, 1958; 1967), originated from shelf depocenters that fed landward eolian sand transport during late-Pleistocene marine low-stands (Peterson et al., 2007; 2015, 2017a). Shoreward wave sand transport during the Holocene marine transgression contributed littoral sand to the dune sheets, though latest-Holocene dune development was locally influenced by long-shore littoral transport (Peterson et al., 2009). Nearing the conclusion of these regional dune sheet studies, it was discovered that the Santa Maria-Vandenberg study area provided exceptional resolution of the relations between paleo-shoreline orientations, paleo-wave climate, and longshore sand transport mechanisms of coastal sand supply, as outlined below.

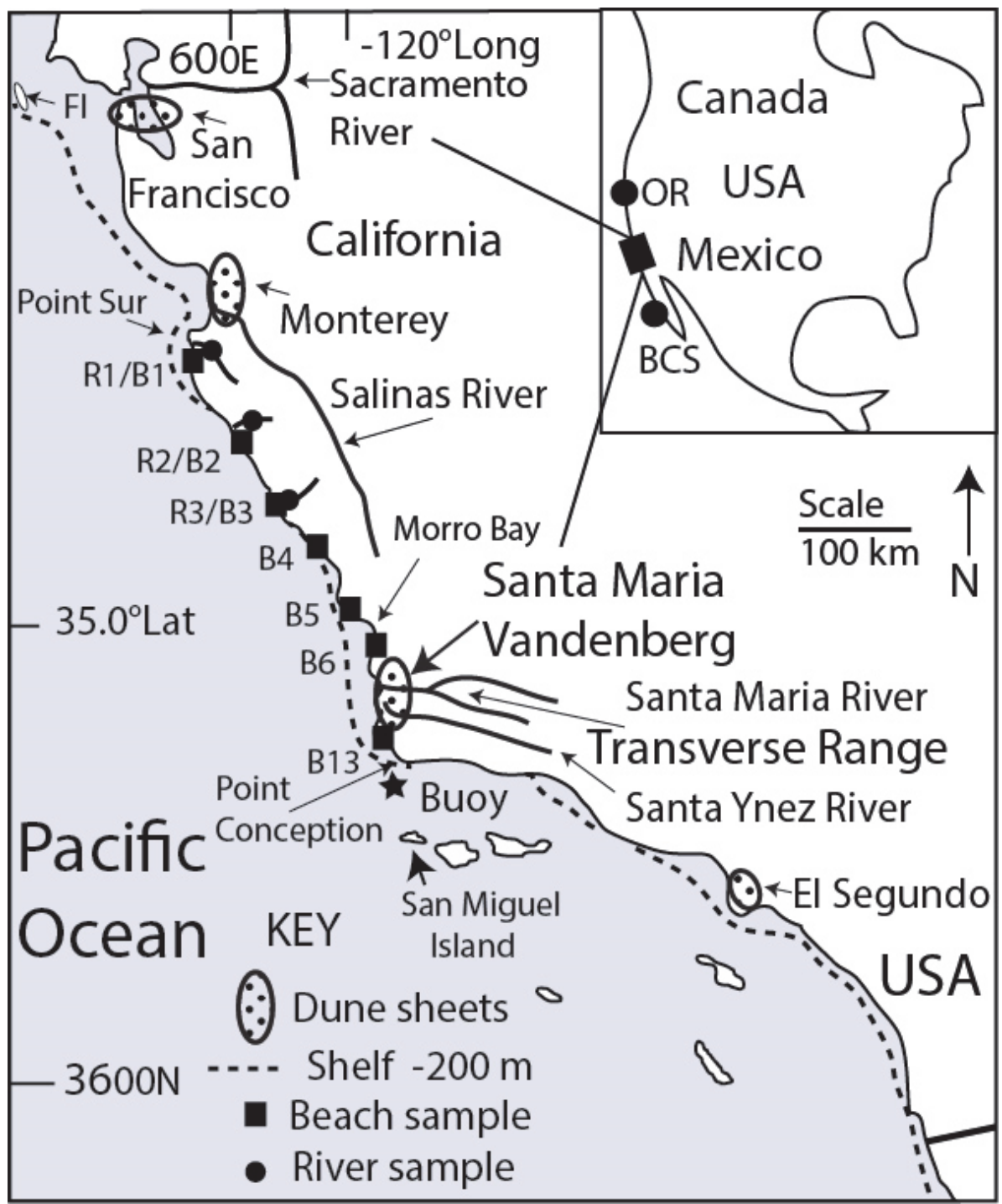

Figure 1. Locations of the Santa Maria and Vandenberg coastal dune sheets

The Santa Maria and Vandenberg coastal dune sheets (stippled pattern) are shown in the south-central coast of California, within the central West Coast of North America (inset). The Santa Maria River, and its two tributaries the Cuyama River (north) and Sisquok river (south) and the Santa Ynez River (bold lines) run through the paleo-dune sheets. Headwaters of the Santa Maria and Santa Ynez Rivers originate within the Transverse Ranges, which form the south-central California bight. Mid-latitude coastal dune sheets also occur at San Francisco, Monterey, and El Segundo. Very-large Quaternary coastal dune sheets occur in Oregon (OR) and Baja California Sur (BCS) as approximately located in the map inset.

A group of late-Quaternary dune sheets ( $280 \mathrm{~km}$ in total length) occurs along the Oregon coast (Figure 1, inset map), at distances of 900-1,200 km north of the Santa Maria and Vandenberg study area (Cooper, 1958). Net 
northward littoral transport along marine low-stand shorelines in Oregon accumulated sand against an emerged shelf bight/bank complex during late-Pleistocene time (Peterson et al., 2007). Cross-shelf sand transport to the Oregon dunes occurred by eolian processes during late-Pleistocene marine low-stands (75-20 ka) and by shoreward wave transport during the following Holocene marine transgression. The closer San Francisco dune sheet, located $\sim 350 \mathrm{~km}$ north of the Santa Maria/Vandenberg study area, originated from a slight northward transport of littoral sand, supplied by the Sacramento-San Joaquin river system, which developed a low-stand depocenter at the Farallon Islands (Peterson et al., 2015). The Farallon low-stand depocenter then fed eolian sand transport across the emerged shelf in late-Pleistocene time and ocean wave sand transport across the inner-shelf in middle-Holocene time. In late-Holocene time $(\leq 5 \mathrm{ka})$, the littoral sand supply to the San Francisco dune fields diminished. It was not established whether the decrease in dune sand supply resulted from 1) terminated transgression shoreward-wave sand transport, or 2) onset of southward littoral sand transport. Two very-large dune sheets in Baja California Sur, Magdalena and Guerrero Negro, located respectively at $\sim 980$ and $\sim 1,350 \mathrm{~km}$ southeast of the Santa Maria/Vandenberg study area, originated from consistent southeast littoral sand transport during both late-Pleistocene marine low-stands and the Holocene marine transgression (Peterson et al., 2017a). The paleo-shoreline orientations of the Baja California Sur west coast were insufficiently orthogonal to paleo-wave forcing directions to discriminate between potentially small changes in paleo-wave directions, as based coastal dune depositional records.

The Santa Maria and Vandenberg dune sheets are located near the southern boundary of a persistent winter storm wind and wave generation area in the northeast Pacific Ocean, referred to here as the North Pacific Low Pressure Area (NPLPA) (Alder and Hostetler, 2015; Peterson et al., 2017b). The two dune sheets also occur in an area of locally anomalous shoreline orientation (north-south), resulting from tectonic uplift of the Point Conception coastal region (Figure 1) (Orme, 1999). A net southward littoral transport in the study area, from Morro Bay to south of Point Conception (Figure 1), was reported by Trask (1952), as based on augite tracer minerals in the modern beach sands. These unique conditions permit the use of the Santa Maria and Vandenberg dune sheets to formally test fundamental relationships between paleo-wave climates, paleo-shoreline orientations, and large-scale coastal sand supply within the Central West Coast of North America region. Coastal dune sheets serve as long-term records of coastal sand supply due to their preservation above the reach of marine transgressions and associated erosive wave ravinement. However, establishing the timing of coastal sand supply to coastal dune sheets is complicated by local topography and paleo-climate conditions that could influence eolian sand transport. These difficulties are overcome in the Santa Maria and Vandenberg dune sheets (Figure 1) by dating the major dune field advances and correlating the dune deposit ages to the longshore distribution of dune sand volumes. The temporal and spatial constraints of coastal dune sand deposition are then compared to 1) paleo-sea levels (Bard et al., 1990; Reeder-Myers et al., 2015), 2) local paleo-climate records (Anderson et al., 2015), 3) modeled regional paleo-wind/wave stress (Alder and Hostetler, 2015), and 4) continental shelf bathymetry/paleo-shoreline orientations. Results of these comparisons discriminate between paleo-sea level change, paleo-wave forcing, and paleo-shoreline orientations and their control over large-scale coastal sand supply to the Santa Maria and Vandenberg study area. Findings from this study address both 1) large-scale geomorphic development of large coastal dune sheets in late-Quaternary time and 2) the potential for future beach erosion resulting from rising sea levels, given the trend of increasing global temperature (Kopp et al., 2014).

\section{Background}

\subsection{Geomorphic Settings}

Major reorientation and widening of the south-central California coast and continental shelf, from north to south in the study area, are attributed to Neogene tectonic uplift of the Transverse Ranges (Figure 1) (Orme, 1999). For example, coastline orientations and shelf widths change from southeast trending $\left(\sim 135^{\circ} \mathrm{TN}\right)$ and narrow widths ( 1-7 km across-shelf distance), north of the Estero Embayment (Figure 2), to more southerly orientations ( $\left.190^{\circ} \mathrm{TN}\right)$ and broader shelf widths ( $\sim 10-25 \mathrm{~km}$ in across-shelf distance) between the Estero Embayment and Point Arguello. This change in shoreline orientation, from north to south, relative to modern deep-water wave directions, shifts incident wave attack from oblique along the northernmost coastline to nearly orthogonal along the southern coastline of the study region.

The complex topography of the study area coastline (Figure 2) derives from a series of high-angle Quaternary faults that intersect the coast at normal to slightly oblique angles (Lettis and Hanson, 1992). Uplifted fault blocks form major points or littoral subcell headlands, including those at Point San Luis, Point Sal, Purisima Point, and Point Arguello. Fault-bounded river valleys include the Santa Maria and Santa Ynez River valleys. The Santa Maria and Vandenberg dune sheets are generally located within Quaternary basins, which are bounded by 
uplifted fault blocks at Point San Luis, Point Sal, and Point Arguello (Lettis and Hanson, 1992). At smaller spatial scales, the landward extents of the Santa Maria and Vandenberg dune sheets are influenced by local topographic features. For example, the Santa Maria dune sheet is split into the north and south sides of the wide Santa Maria River Valley (Figure 2), which was deeply incised to at least $30 \mathrm{~m}$ depth (- $30 \mathrm{~m}$ elevation MSL) during the last marine low-stand, and then back-filled by alluvial deposits during the Holocene marine transgression (11-0 ka) (Knott and Eley, 2006).

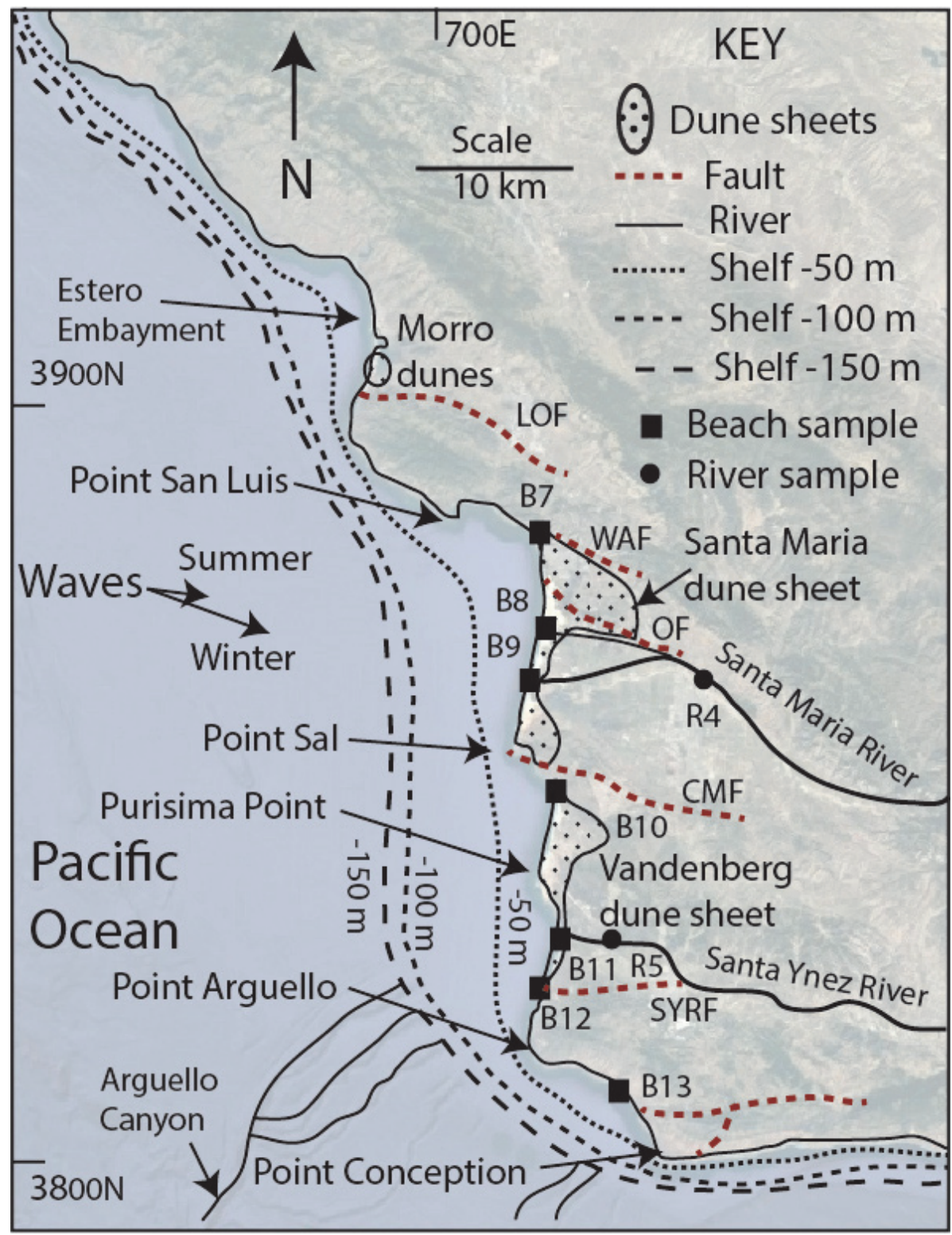

Figure 2. Geomorphic settings of the Santa Maria and Vandenberg dune sheets

The dune sheets are shown relative to (1) shoreline orientations (northern segment $\sim 135^{\circ} \mathrm{TN}$, southern segment $\sim 190^{\circ} \mathrm{TN}$ ), (2) shelf contours (-50, -100 and $-150 \mathrm{~m}$ elevation, relative to mean sea level (MSL), (3) two major coastal rivers: the Santa Maria River and the Santa Ynez River, and (4) high-angle faults (dashed bold line). High-angle faults that intercept the modern coastline (Lettis and Hanson, 1992) are as follows from north to south: Los Osos fault (LOF), Pismo fault (PMF), Wilmar Avenue fault (WAF), Oceano Fault (OF), Casmalia fault (CMF), and Santa Ynez River Fault (SYRF). Submarine canyons (bold lines) intercept the outer-shelf offshore of Point Arguello and Point Conception. Mean deep-water wave directions (arrows) for winter months (DJF) and summer months (JJA) for years 2014-2015 were averaged from an offshore wave buoy (Figure 1) as summarized in Peterson et al. (2017b). 
The Vandenberg dune sheet reaches maximum widths $(\sim 7 \mathrm{~km})$ north of the Purisima Point headland (Figure 2). Paleo-transverse dune ramps on the southwest side of the Santa Maria River valley ascend (5-10\% gradient) to elevations of at least $100 \mathrm{~m}$ MSL along the Point Sal Ridge (Figure 3A) (Orme, 1992). The minor headland at Purisima Point is associated with local up-warping of resistant marine terrace(s) dated to marine isotope stage 5 (MIS5) high-stands at 120-85 ka (Lettis and Hanson, 1992). The marine terrace platform(s) dip to the southwest (110 to $5 \mathrm{~m}$ elevation over $10 \mathrm{~km}$ ) to yield gradual slopes (1-2\% gradient) that do not prohibit, but possibly influence, landward dune migration. Large parabolic dunes (5-10 m height) trend obliquely $\left(\sim 120-140^{\circ} \mathrm{TN}\right)$ away from the shoreline yielding the southeast-directed migratory dune transport over the broad slightly tilted marine terrace (Figure 3B). The southern part of the Vandenberg dune sheet abruptly narrows $(<1.0 \mathrm{~km}$ width) south of the Santa Ynez River in association with 30-70 m uplift(s) of older marine terraces (MIS7 and/or MIS9) at the present coastline (Lettis and Hanson, 1992). Steep Holocene seacliffs, which are cut into the uplifted terraces at the southernmost end of the Vandenberg dune sheet (Johnson et al., 1991), possibly reduced dune sheet widths. However, the steep seacliff or windward bluff slopes did not preclude coastal eolian sand ramps (Peterson et al., 2017b) from reaching $\sim 50 \mathrm{~m}$ elevations at $\sim 0.5 \mathrm{~km}$ landward distances from modern beach backshores.
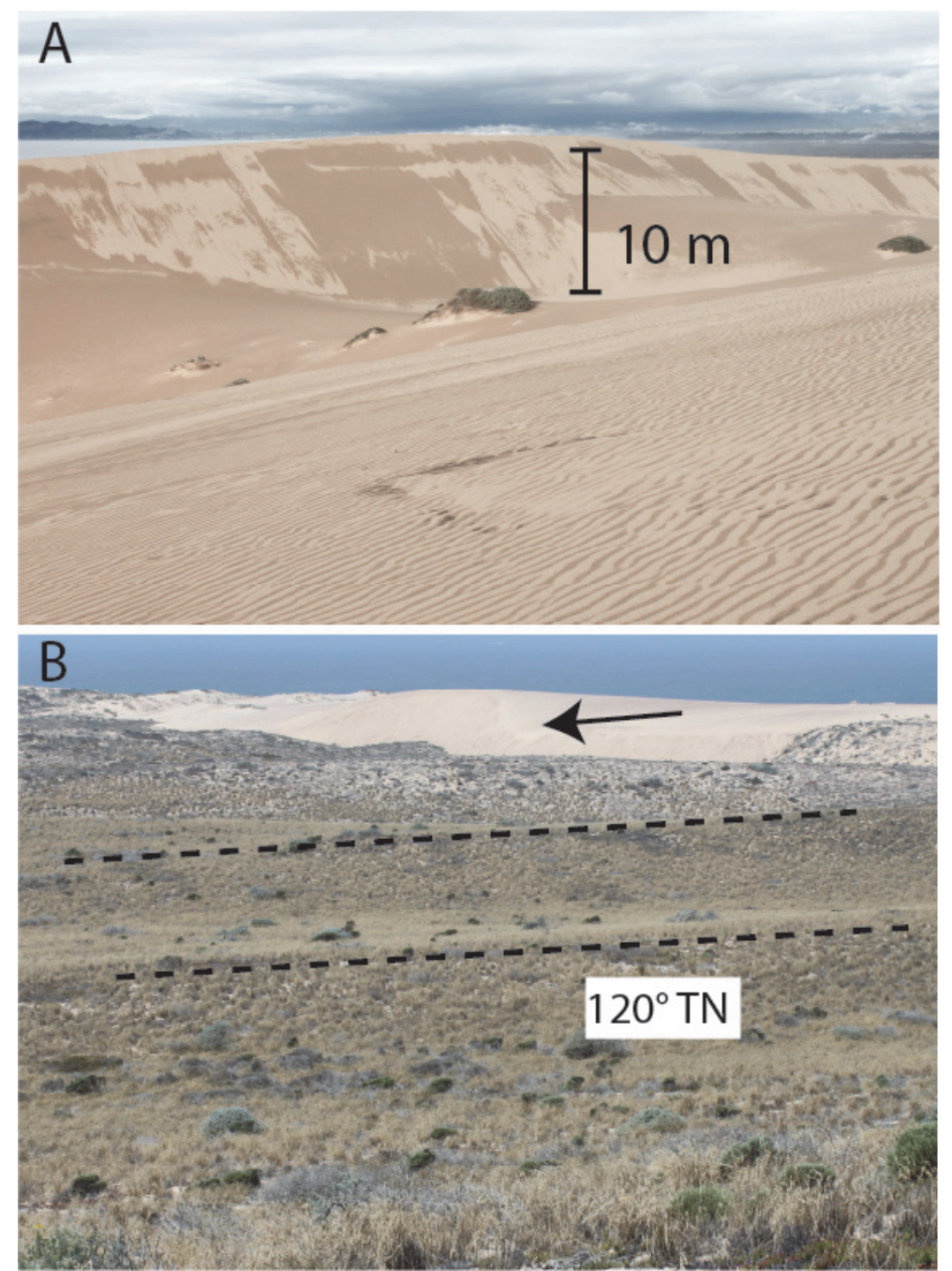

Figure 3. Active and recently stabilized dune fields in the study area

Part A: Large active transverse dunes $(10 \mathrm{~m}$ height), located near the south end of the Guadalupe dune field within the Santa Maria dune sheet (Figure 2), are migrating upslope towards the southeast $\left(\sim 160^{\circ} \mathrm{TN}\right)$, forming a dune ramp $\left(10^{\circ}\right.$ gradient) against the uplifted Point Sal Ridge ( 150 m elevation) near site S34 (Table 2$)$. View is to the north. Part B: Large parabolic dunes (5-10 m height) in the northern Vandenberg dune sheet include active dunes (arrow) and recently vegetated dune ridges (dashed lines). The photograph is from site V7 (Table 2), located within a sparsely vegetated dune field, located $\sim 4 \mathrm{~km}$ landward of the shoreline (Figure 2). The parabolic dunes trend southeast $\left(120^{\circ} \mathrm{TN}\right)$. View is to the southwest. 


\subsection{Paleo-sea Level Curves}

High-energy wave erosion from multiple late-Pleistocene marine transgressions truncated much of the topographic relief on the continental shelf in the study area (Figure 2). However, during late-Pleistocene marine low-stands $(-100 \pm 25 \mathrm{~m}$ elevation between 80 and $15 \mathrm{ka})$, the supplies of discharged river sand and remobilized littoral sand could have accumulated in the mid-shelf littoral systems (Figure 4A). During the latest-Pleistocene time and the Holocene marine transgression (16-0 ka), wave ravinement could have remobilized mid-and inner-shelf sand deposits. As found for the nearby San Miguel Island (Figure 1) (Johnson, 1972), a shoreward wave transport could have delivered available shelf sand to the study area beaches and migratory dune fields following declining rates of sea level rise after $9 \mathrm{ka}$ (Figure 4B) (Masters, 2006). Asymmetric wave transport can move sand from continental low-stand deposits shoreward during marine transgressions. Surplus beach sand supplies onshore eolian transport to develop coastal dunes during the slowing phase of marine transgression, as reported for South East Australia (Thom, 1984; Short, 1987) and many other coastlines around the world. The near high-stand conditions of latest-Holocene time (3-0 ka) could have been associated with the reduction or termination of transgressive sand supply in the Santa Maria and Vandenberg dune sheet areas, as found for the small San Miguel Island (Peterson et al. 2017b). However, the near high-stand sea levels would have been associated with relatively stable shoreline conditions for longshore littoral transport in the nearshore and inner-shelf of the continental margin between Point Sur and Point Conception (Figure 1). Such redistribution of sand in the littoral zone could then locally supply latest-Holocene dune development at subcell catchments (Peterson et al., 2009).

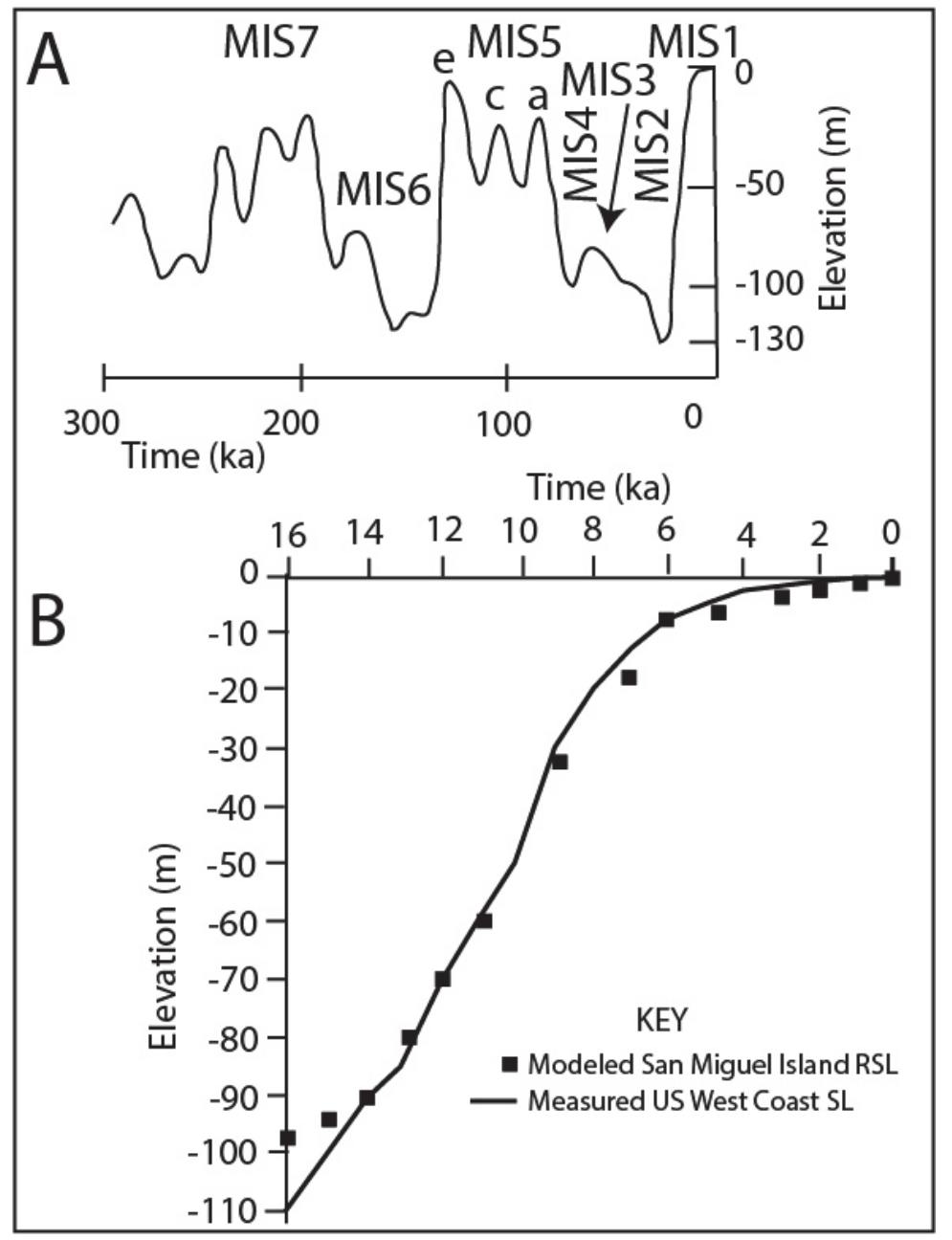

Figure 4. Sea level curves for the study region

Part A: Eustatic sea level curve from late-Quaternary time (300-0 ka), as redrawn from Bard et al. (1990). Part B: Relative sea level (RSL) rise for the Holocene marine transgression, as reported for the central west coast of North America (solid line) and modeled for the south-central California coastal region (solid squares). Figure is redrafted from Peterson et al. (2017b). 


\subsection{Paleo-Climate Records}

Paleo-climate records, based on dated pollen stratigraphy in offshore and onshore core sites, establish the potentials for river sediment supply and eolian transport during paleo-dune sheet development in the study area (Figure 2). The modern coastal climate is characterized by a fog-modulated semi-arid Mediterranean climate with a mean temperature of $14^{\circ} \mathrm{C}$ and a mean annual precipitation of $30 \mathrm{~cm}$, yielding mixed coastal sage scrub and oak woodland/grass savanna communities (Huesser, 1995). During the last glacial interval, the mean temperature dropped to $\sim 5^{\circ} \mathrm{C}$ and annual precipitation reached $60-100 \mathrm{~cm} \mathrm{yr}^{-1}$, as based on conifer taxa from the Transverse and Coast Range drainages. The increased precipitation (2-3 times greater relative to modern levels) should have substantially increased river sediment discharge to the continental shelf during late-Pleistocene time. However, the coastal lowlands remained marginally-semi arid, as shown by a lack of redwood tree pollen in glacial period deposits (Huesser, 1995). The glacial period changed to abrupt warming at $14 \mathrm{ka}$ and drying conditions throughout the Holocene. Local creek floodplain and pond pollen records from the Vandenberg dune sheet area (Anderson et al., 2015) record communities of coastal sage scrub and woodlands by $\sim 9$ ka, with declining oak woodland communities until $4.8 \mathrm{ka}$. Continued drying lead to grassland and coastal sage communities during late-Holocene time (Anderson et al., 2015). Semi-arid coastal conditions in the study area should have promoted 1) eolian sand transport in the large migratory dune sheets throughout latest-Pleistocene and Holocene time and 2) reactivation/remobilization of some pre-existing late-Pleistocene dune and alluvium deposits in Holocene time.

\subsection{Late-Quaternary Sand Deposits}

Late-Quaternary sand deposits in the study area are informally identified as the Orcutt Formation of Pleistocene age (Woodring and Bramlette, 1950: Dibblee, 1950; Worts, 1951) and younger sands of Holocene age (Cooper, 1967). The Orcutt sand members include sand deposits from 1) Pleistocene alluvial or uplifted beach deposits, 2) Pleistocene coastal dune deposits, and 3) locally remobilized or winnowed dune deposits from pre-existing Pleistocene sand sources. The locally remobilized paleo-dune deposits are characteristically thin, generally reaching only a few meters in thickness. By comparison, the thicker migratory paleo-dune sheets reach $10 \mathrm{~s}$ of meters in thickness. The migratory paleo-dune deposits pinch-out with increasing landward distance $(1-15 \mathrm{~km})$ from the present coastline (Figure 2), suggesting their origins from marine/beach sand sources (Cooper, 1967).

Paleo-dune sand supply in the Santa Maria dune sheet has been ${ }^{14} \mathrm{C}$ dated to latest-Pleistocene time $(\sim 29-23 \mathrm{ka})$ (Orme, 1992) and to latest-Holocene time $(<3.5 \mathrm{ka})$ (Knott and Eley, 2006). The Pleistocene migratory dune deposits at the south end of the Santa Maria dune sheet were reportedly related to marine sand sources, though interpretations of specific sand supply origins differ from 1) supply during marine regression and river valley incision to 2) supply during glacial marine low-stands (Orme, 1992). The onset of Holocene dune development in the study area is locally dated to 8-9 ka in sea cliff exposures from the south end of the Vandenberg dune sheet (Johnson et al., 1991), but ages of the much broader dune deposits in the northern part of the Vandenberg dune sheet were not formally differentiated. The first objective of this study is to establish the source(s) of dune sand supply to the Santa Maria and Vandenberg coastal dune sheets. The paleo-dune sheet deposits were then analyzed for thickness and age.

\section{Methods}

\subsection{Sampling Rivers, Beaches, and Paleo-Dune Deposits for Sand Source Indicators}

Modern river and beach sand deposits and paleo-dune deposits were sampled for texture and lithic fragment abundance from the study region between Point Sur to the north and Point Conception to the south (Figures 1 and 2; Table 1). The river, beach, and paleo-dune samples were analyzed for 1) dominant sand sizes, 2) dry color, 3 ) percent lithic rock fragments, and 4) heavy mineral rounding. Sample dominant grain sizes were visually estimated from AM/CAN Stratigraphic ${ }^{\mathrm{TM}}$ grain size cards as follows: very fine lower (vfL) 6-88 $\mu \mathrm{m}$, very fine upper (vfU) $88-125 \mu \mathrm{m}$, fine lower (fL) $125-177 \mu \mathrm{m}$, fine upper (fU) $177-250 \mu \mathrm{m}$, medium lower (mL) 250 $350 \mu \mathrm{m}$, medium upper (mU) 350-500 $\mu \mathrm{m}$, coarse lower (cL) 500-710 $\mu \mathrm{m}$, and coarse upper (cU) 710-1000 $\mu \mathrm{m}$. Sand color, lithic fragment abundance, and heavy mineral roundness analyses were performed on fine upper (fU) -to- medium lower $(\mathrm{mL})$ grain size splits $(175-350 \mu \mathrm{m}$ grain size range), which represent the dominant grain size distributions of dune sand in the study area. Sand dry color is based on Munsell soil color chart (Birkeland, 1999). Light-mineral and heavy-mineral fractions were mounted in Piccolyte ${ }^{\mathrm{TM}}$ resin for petrographic microscopy analysis at 250x. The relative abundances of lithic-fragments grains within the light-mineral components were established from 250 grain counts per sample. The non-lithic grains in the light-mineral component were dominantly mono-crystalline quartz and feldspar. Relative grain roundness was established for colored mono-crystalline heavy-mineral grains. Grain roundness analyses were performed on pyroxenes and 
amphiboles, which represent common and readily distinguishable minerals of intermediate abrasion resistance in the study region (Peterson et al., 2015). Grain roundness was estimated from visual comparison with an $\mathrm{AM} / \mathrm{CAN}^{\mathrm{TM}}$ grain rounding card from 50 grain counts per sample. The relative roundness categories are as follows: angular $=1$, subangular $=2$, subrounded $=3$, rounded $=4$, and well-rounded $=5$. The frequencies of grains in each of the five rounding categories were normalized to yield values of 1 to 5 in order of increasing rounding.

Table 1. Locations of modern river and beach sand sample sites

\begin{tabular}{llcl}
\hline $\begin{array}{l}\text { Site } \\
\text { number }\end{array}$ & $\begin{array}{l}\text { Site } \\
\text { name }\end{array}$ & UTMn (m) & UTMe (m) \\
\hline River & Big Sur River & 4016410 & 603790 \\
R1 & Lime Kiln Creek & 3985930 & 633450 \\
R2 & San Carpoforo Creek & 3959000 & 651620 \\
R3 & Santa Maria River & 3872710 & 736940 \\
R4 & Santa Ynez River & 3840400 & 726190 \\
R5 & & \\
Beach & Big Sur Beach & 4015710 & 602640 \\
B1 & Lime Kiln Beach & 3985950 & 633410 \\
B2 & San Carpoforo Beach & 3958110 & 652140 \\
B3 & Wind Surf Beach & 3946920 & 660980 \\
B4 & Cayucos Beach & 3924890 & 689940 \\
B5 & Morro Beach & 3918660 & 693930 \\
B6 & 3890740 & 714850 \\
B7 & Pismo Beach & 3879370 & 715860 \\
B8 & Oso Flaco Beach & 3871710 & 714510 \\
B9 & SBC Park Beach & 3859730 & 718620 \\
B10 & Minuteman Beach & 3840480 & 719310 \\
B11 & Surf Beach & 3832340 & 716840 \\
B12 & Honda Beach & 3821800 & 729200 \\
B13 & Jalama Beach & \\
\hline
\end{tabular}

Notes: Modern River and Beach sample locations are in UTM (10S) meters (m) in northings (n) and eastings (e). River samples were collected in bank bars. Beach samples were collected in summer beach berm or backshore locations.

\subsection{Mapping the Migratory Paleo-Dune Deposits}

In this study, several methods were used to establish the extents of paleo-dune sheet deposits, including interpretation of active- and sparsely-vegetated dune features in modern satellite images and examinations of subsurface morphostratigraphic sections. The morphostratigraphic sections were measured in road-cut exposures, 2) shallow hand-auger holes (3-10 m depths subsurface) with a $7.5 \mathrm{~cm}$ diameter Doormer Sand Auger $\left.{ }^{\mathrm{TM}}, 3\right)$ reviews of deeper geotechnical borehole logs (10-30 m depth subsurface) and deeper water well logs (30-100 m depth), and 4) upslope sea cliff and gully-cut traverses (30-100 m adjusted vertical sections). Section site coordinates and elevations are from 12 Channel-WAS GPS and GIS-DEMs (reported to the nearest $5 \mathrm{~m}$ elevation) or reported borehole survey data. The positions and elevations of the morphostratigraphic sections used in this article are presented in Table 2. The representative morphostratigraphic sections were analyzed for sand deposit grain size texture, including size and sorting, with AM/CAN Stratigraphic ${ }^{\mathrm{TM}}$ grain size cards. The morphostratigraphic sections were analyzed for soil profile development, including soil color and paleosol development (Birkeland, 1999), and a measure of relative cementation or unconfined shear strength $\left(\mathrm{kg} \mathrm{cm}^{-2}\right)$ by pocket penetrometer (Peterson et al., 2006). Standard penetration test (SPT) values or blow counts per $15 \mathrm{~cm}$ drive intervals, ASTM Standard Guide D5434-12 (ASTM, 2017), from reported borehole records, are used to supplement the pocket penetrometer data in extended (deeper) geotechnical borehole sections.

Table 2. Positions and elevations of morphostratigraphic sections

\begin{tabular}{llllllll}
\hline Section & UTMn & UTMe & Elev. & Section & UTMn & $\begin{array}{l}\text { UTMe } \\
(\mathrm{m})\end{array}$ & $\begin{array}{l}\text { Elev. } \\
(\mathrm{m})\end{array}$ \\
No. & $(\mathrm{m})$ & $(\mathrm{m})$ & $(\mathrm{m})$ & No. & $(\mathrm{m})$ & $(\mathrm{m})$ \\
\hline
\end{tabular}




\begin{tabular}{|c|c|c|c|c|c|c|c|}
\hline S1 & 3891050 & 714770 & 5 & V3 & 3859210 & 719340 & 45 \\
\hline S2 & 3889980 & 715820 & 10 & V4 & 3857700 & 720800 & 85 \\
\hline S3 & 3888930 & 718119 & 30 & V5 & 3857700 & 721800 & 70 \\
\hline S4 & 3888400 & 717620 & 20 & V6 & 385700 & 722900 & 110 \\
\hline S5 & 3887280 & 719180 & 25 & V7 & 3854780 & 721430 & 60 \\
\hline S6 & 3887180 & 718590 & 20 & V8 & 3853980 & 724040 & 120 \\
\hline S7 & 3886960 & 720850 & 50 & V9 & 3853700 & 720830 & 65 \\
\hline S8 & 3885590 & 717150 & 15 & V10 & 3853600 & 724320 & 105 \\
\hline S9 & 3885420 & 720330 & 70 & V11 & 3853390 & 719740 & 40 \\
\hline S10 & 3884710 & 719970 & 55 & V12 & 3852840 & 720760 & 60 \\
\hline S11 & 3883930 & 722770 & 105 & V13 & 3852460 & 723480 & 80 \\
\hline $\mathrm{S} 12$ & 3882390 & 724440 & 135 & V14 & 3852100 & 720710 & 25 \\
\hline S13 & 3882290 & 722180 & 85 & V15 & 3852290 & 722810 & 70 \\
\hline S14 & 3882050 & 726380 & 125 & V16 & 3852270 & 721490 & 40 \\
\hline S15 & 3881910 & 727860 & 115 & V17 & 3852120 & 718710 & 40 \\
\hline S16 & 3881900 & 720370 & 35 & V18 & 3851740 & 722610 & 45 \\
\hline S17 & 3880230 & 724590 & 80 & V19 & 3851330 & 718950 & 55 \\
\hline S18 & 3881420 & 718990 & 35 & V20 & 3851070 & 721890 & 55 \\
\hline S19 & 3879710 & 724400 & 80 & V21 & 3850820 & 718230 & 60 \\
\hline S20 & 3878740 & 723230 & 90 & V22 & 3850090 & 718580 & 60 \\
\hline 21 & 3878090 & 725730 & 100 & V23 & 3850090 & 727740 & 200 \\
\hline S22 & 3878140 & 727020 & 95 & V24 & 3848910 & 720420 & 85 \\
\hline S23 & 3877250 & 726450 & 115 & V25 & 3848790 & 718750 & 65 \\
\hline S24 & 3877180 & 727230 & 105 & V26 & 3848660 & 716840 & 35 \\
\hline S25 & 3876960 & 728560 & 90 & V27 & 3848540 & 721150 & 85 \\
\hline F5 & 3874500 & 716500 & 25 & V28 & 3848810 & 721550 & 95 \\
\hline S26 & 3875460 & 719370 & 40 & V29 & 3848400 & 718400 & 70 \\
\hline $\mathrm{TM}$ & 3874000 & 717000 & 25 & V30 & 3846950 & 718290 & 30 \\
\hline S27 & 3872620 & 716610 & 50 & V31 & 3846900 & 718900 & 50 \\
\hline S28 & 3870900 & 716000 & 25 & V32 & 3845350 & 719170 & 30 \\
\hline S29 & 3869510 & 714170 & 30 & V33 & 3844600 & 719200 & 20 \\
\hline $\mathrm{S} 30$ & 3868260 & 718630 & 125 & V34 & 3844440 & 722030 & 100 \\
\hline S31 & 3868000 & 718620 & 135 & V35 & 3843240 & 719690 & 15 \\
\hline S32 & 3867770 & 729280 & 60 & V36 & 3842950 & 720160 & 20 \\
\hline S33 & 3868210 & 714720 & 145 & V37 & 3840760 & 719680 & 25 \\
\hline S34 & 3867690 & 713990 & 135 & V38 & 3838950 & 719910 & 35 \\
\hline OR & 3867500 & 714500 & 160 & V39 & 3838100 & 718740 & 45 \\
\hline S35 & 3867050 & 713950 & 150 & V40 & 3837420 & 718770 & 60 \\
\hline S36 & 3866790 & 713570 & 95 & V41 & 3837070 & 719570 & 40 \\
\hline 37 & 3866300 & 716000 & 260 & V42 & 3837000 & 718700 & 65 \\
\hline S38 & 3865970 & 716640 & 340 & V43 & 3835130 & 718300 & 90 \\
\hline S39 & 3865300 & 713740 & 160 & V44 & 3834300 & 718070 & 90 \\
\hline S40 & 3860200 & 732330 & 105 & V45 & 3833000 & 717250 & 60 \\
\hline V1 & 3860310 & 718710 & 35 & V46 & 3833180 & 716920 & 55 \\
\hline $\mathrm{V} 2$ & 3859730 & 718620 & 20 & V47 & 3831970 & 716790 & 35 \\
\hline
\end{tabular}

Notes: Morphostratigraphic sections are from the Santa Maria (S) and Vandenberg (V) dune sheets, this article. Drill sites F5 and TM are from Knott and Eley (2006). Site OR is combined from Orme (1992) Mussel Rock gully sites B and E. Section site coordinates are in UTM meters (rounded to the nearest $10 \mathrm{~m}$ ). Elevation $(\mathrm{m})$ is estimated to the nearest 5 meters using GPS position data and GIS-DEM. Compiled sections from sea-cliff and gully-cut traverses are shown in bold. Their site positions are given from the top of the section.

\subsection{Dune Deposit Thermoluminescence (TL) Dating}

A total of six new thermoluminescence (TL) samples from the Santa Maria and Vandenberg dune sheets were analyzed for ages using standardized laboratory methods (TL Laboratory Data in Supplementary Materials). The TL dating method has been tested against ${ }^{14} \mathrm{C}$ and OSL dating methods in several other coastal dune sheets in the 
Central West Coast of North America (Peterson et al., 2006; Peterson et al., 2007; Peterson et al., 2015; Peterson et al., 2017a). TL dating is a reliable reconnaissance dating method for dune sheet sand deposits, which are assumed to have been essentially fully reset by sun light during episodic eolian transport, prior to deposition (Aitken, 1985). The TL samples used in this study were analyzed at the University of Wollongong, Wollongong, Australia.

\section{Results}

\subsection{Sources of Modern Beach and Paleo-Dune Sand}

Modern river and beach deposits sampled in the study area (Figures 1 and 2) are coarser in dominant grain size $(\mathrm{cL} / \mathrm{mU})$ than representative paleo-dune deposits $(\mathrm{mL} / \mathrm{fU})$ in the Santa Maria and Vandenberg dune sheets (Table 3). Therefore, river and beach sand source indicators, including lithic fragment abundance and heavy-mineral rounding, are based on the dominant dune sand sizes (fU/mL) sieved at 175-350 $\mu \mathrm{m}$ from the river and beach samples. River sand is represented by relatively high lithic fragment abundance (48-54 percent) in the light mineral fraction and modest grain angularity (1.7-2.7 roundness) in the heavy mineral fraction. Recycled marine sandstones, meta-sedimentary rocks, and igneous rocks in the Coast Range and Transverse Range river drainages (Yancey and Lee, 1972; Scott and Williams, 1978) likely account for the modest angularity of the pyroxene and amphibole sand grains in the river sand samples. Similar bedrock lithologies in modern beach cliffs could yield similar sand textural maturities, so river and eroding sea cliff sand sources are lumped together in this study of coastal sand supply.

Table 3. Grain size, color, lithic abundance and rounding of sand in river, beach and paleo-dune deposits

\begin{tabular}{|c|c|c|c|c|c|}
\hline $\begin{array}{l}\text { Sample } \\
\text { site }\end{array}$ & $\begin{array}{l}\text { Bulk } \\
\text { dominant } \\
\text { grain size }\end{array}$ & $\begin{array}{l}\text { Dry } \\
\text { color }\end{array}$ & $\begin{array}{l}\text { Light } \\
\text { mineral } \\
\text { lithics }(\%)\end{array}$ & $\begin{array}{l}\text { Heavy } \\
\text { mineral } \\
\text { roundness }\end{array}$ & $\begin{array}{l}\text { Beach/ } \\
\text { foredune width (m) }\end{array}$ \\
\hline \multicolumn{6}{|l|}{ River } \\
\hline R1 & $\mathrm{mU}$ & 10YR6/2 & 54 & 2.3 & na \\
\hline R2 & cL & 10YR6/3 & 50 & 1.7 & na \\
\hline R3 & $\mathrm{cL}$ & 10YR5/2 & 53 & 2.1 & na \\
\hline R4 & $\mathrm{mU}$ & 10YR6/3 & 48 & 2.5 & na \\
\hline R5 & $\mathrm{mU}$ & 10YR6/2 & 52 & 2.7 & na \\
\hline \multicolumn{6}{|l|}{ Beach } \\
\hline B1 & $\mathrm{cL}$ & 10YR6/2 & 45 & 2.6 & 50 \\
\hline B2 & $\mathrm{cU}$ & 10YR5/1 & 46 & 2.5 & 25 \\
\hline B3 & $\mathrm{cU}$ & 10YR4/2 & 42 & 2.4 & 50 \\
\hline B4 & $\mathrm{cL}$ & 10YR6/2 & 35 & 2.7 & 50 \\
\hline B5 & $\mathrm{cL}$ & $2.5 \mathrm{Y} 6 / 2$ & 33 & 3.1 & 50 \\
\hline B6 & $\mathrm{mU}$ & $2.576 / 2$ & 31 & 3.8 & 250 \\
\hline B7 & $\mathrm{mL}$ & $2.5 \mathrm{Y} 7 / 3$ & 33 & 3.9 & 200 \\
\hline B8 & $\mathrm{mU}$ & $2.5 \mathrm{Y} 7 / 4$ & 30 & 4.1 & $>250$ \\
\hline B9 & $\mathrm{mU}$ & $2.5 \mathrm{Y} 7 / 4$ & 31 & 4.0 & $>250$ \\
\hline B10 & $\mathrm{mU}$ & $2.5 \mathrm{Y} 7 / 3$ & 29 & 4.2 & 200 \\
\hline B11 & $\mathrm{mL}$ & $2.5 \mathrm{Y} 7 / 2$ & 25 & 4.1 & 150 \\
\hline B12 & $\mathrm{mU}$ & $2.5 \mathrm{Y} 7 / 2$ & 28 & 4.0 & 50 \\
\hline B13 & $\mathrm{cL}$ & $2.5 \mathrm{Y} 7 / 4$ & 26 & 4.3 & 30 \\
\hline \multicolumn{6}{|l|}{ Paleo-dune } \\
\hline S8 & $\mathrm{fU} / \mathrm{mL}$ & 10YR6/4 & 31 & 4.1 & na \\
\hline S9 & $\mathrm{mL}$ & $7.5 Y R 8 / 4$ & 29 & 3.8 & na \\
\hline S13 & $\mathrm{mL}$ & 10YR6/3 & 26 & 4.0 & na \\
\hline S14 & $\mathrm{mL} / \mathrm{fU}$ & 10YR7/2 & 28 & 3.9 & na \\
\hline S21 & $\mathrm{mL}$ & 10YR7/6 & 31 & 4.3 & na \\
\hline S32* & $\mathrm{fU}$ & 10YR6/4 & 49 & 2.8 & na \\
\hline S31@2.2m & $\mathrm{mL} / \mathrm{fU}$ & 7.5YR6/6 & 30 & 4.1 & na \\
\hline S34@8.5m & $\mathrm{mL}$ & $7.5 Y R 5 / 4$ & 27 & 4.0 & na \\
\hline V7 & $\mathrm{mL}$ & $2.5 Y 8 / 3$ & 35 & 3.7 & na \\
\hline V8 & $\mathrm{mL} / \mathrm{fU}$ & 7.5YR6/4 & 29 & 4.1 & na \\
\hline
\end{tabular}




$\begin{array}{llllll}\text { V11 } & \mathrm{mL} & 2.5 \mathrm{Y} 8 / 2 & 31 & 3.9 & \mathrm{na} \\ \mathrm{V} 13 & \mathrm{~mL} & 10 \mathrm{YR} 6 / 4 & 28 & 4.0 & \mathrm{na} \\ \text { V24 } & \mathrm{mL} & 10 \mathrm{YR} 8 / 3 & 23 & 4.3 & \mathrm{na} \\ \text { V35@5.0m } & \mathrm{mL} & 7.5 \mathrm{YR} 6 / 6 & 26 & 4.1 & \mathrm{na} \\ \text { V39@2.0m } & \mathrm{mL} / \mathrm{fU} & 2.5 \mathrm{Y} 7 / 4 & 33 & 4.0 & \mathrm{na} \\ \text { V39@12.0m } & \mathrm{mL} & 7.5 \mathrm{YR} 6 / 8 & 31 & 3.9 & \mathrm{na}\end{array}$

Notes: Modern river and beach sand sample locations are shown in Supplementary Table 1. Paleo-dune deposit locations are shown in Table 1 (article). *S32 is a reworked floodplain dune deposit. Paleo-dune deposit samples are taken near the surface except where depths $(\mathrm{m})$ are shown. Dominant grain size was visually estimated from bulk samples using a AM/CAN Stratigraphic ${ }^{\mathrm{TM}}$ grain size card. Dry color, light mineral lithics (\%) (percent multi-crystalline fragments) and roundness of heavy-mineral (mono-crystalline pyroxenes/amphiboles) are measured from sieved grain-size splits $(175-350 \mu \mathrm{m})$. Beach/foredune width is measured landward from the mid-swash zone using satellite images 2013-2016 (Google Earth, 2016).

Beach sand lithology and texture vary widely from relatively high lithic fragment abundance and low rounding of heavy minerals in the northern beaches to low lithic fragment abundance $(<35 \%)$ and relatively high rounding (3.8-4.3 roundness) in the southern beaches (Table 3; Figure 5). The narrow northern beaches (B1-B5 $\leq 50 \mathrm{~m}$ width) reflect recent direct river sand supply. The wider southern beaches (B6-B11 150-250 m width) reflect increased textural maturity of sand grains, which experienced substantial abrasion from prolonged exposure to surf/eolian transport processes in the continental shelf. The modern beach sand samples in the vicinities of the Santa Maria and Vandenberg dune sheets (B7-B12) show moderately high textural maturity (lithic fragment abundance 25-33\% and heavy-mineral roundness 3.9-4.2), which preclude major amounts of river sand supplied directly to the modern beaches from the adjacent Santa Maria and Santa Ynez Rivers (Table 3; Figure 5). Minor amounts of direct river sand supply to the southern beaches, however, likely occurred in latest-Holocene time. Though not observed in the beach sand mineralogy, some through-put of Santa Maria River and Santa Ynez River sand to the adjacent beaches is inferred from 1) late-Holocene aggradation of the lower river valley fills (Knott and Eley, 2006) and 2) river mouth breaching of beach berms during infrequent events of river flooding (Inman and Jenkins, 1999; Stillwater Sciences and Kear Groundwater, 2012).

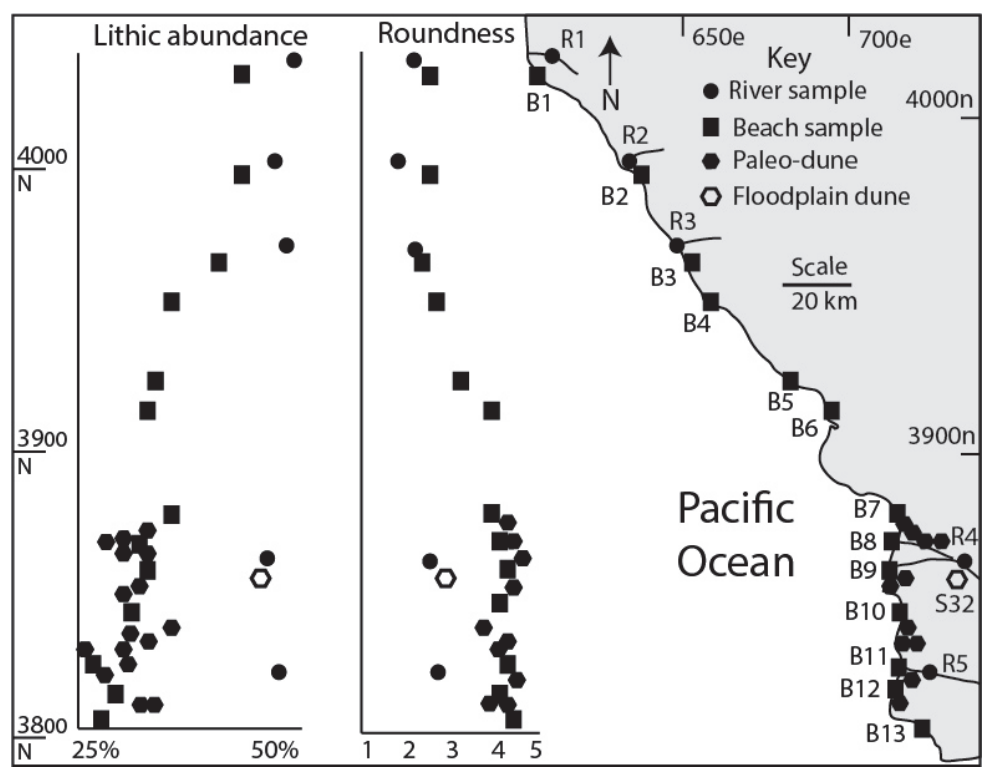

Figure 5. Sand source discrimination in the study area

Sand source indicators, including light-mineral lithic fragment abundance (\%) and heavy mineral rounding (angular=1 to well-rounded=5), of sand grains in the $\mathrm{mL}$ to $\mathrm{fU}(175-350 \mu \mathrm{m})$ size range in river, beach, and representative paleo-dune samples. One paleo-dune sample (S32) is from a winnowed layer (floodplain dune) above river floodplain deposits. Data are from Table 3.

Sand samples from representative paleo-dune deposits in the Santa Maria and Vandenberg dune sheets (Table 3; Figure 5) reflect marine sand supply as based on low lithic fragment abundance (23-35\%) and rounding of heavy-mineral grains (3.7-4.3 roundness). The sole exception is sample S32 (lithic fragments $49 \%$ and 
heavy-mineral roundness 2.8), which is from a winnowed dune hummock in the Santa Maria River floodplain. The coastal dune sheet deposits were not derived from either 1) direct river sand supply or 2) beaches that were directly supplied by river sand throughput, as might have occurred during rapid marine regression and fluvial valley down-cutting (Orme, 1992). Rather, the textural maturity of paleo-dune sands in the Santa Maria and Vandenberg coastal dune sheets reflect dominant supply of abraded sand from the continental shelf. The shelf sand supply could have occurred via cross-shelf transport by eolian processes during marine low-stands and/or by shoreward wave transport during marine transgression.

\subsection{Paleo-Dune Deposit Type Discrimination}

Migratory paleo-dune deposits in the study area were discriminated from uplifted Pleistocene beach sand, winnowed alluvial floodplain sand, and/or slope wash/colluvium on the bases on dominant sand grain size (fU/mU), sorting (well/ very-well sorted), and a lack of gravel. Three relative ages (types) of migratory paleo-dune deposits were identified in the Santa Maria and Vandenberg dune sheets, based on sand deposit weathering or cementation, and absolute dating by $\mathrm{TL}$ or ${ }^{14} \mathrm{C}$ methods. Active or recently-stabilized dune deposits (Figure 3) showed no apparent weathering of shallow subsurface deposits in representative soil profiles. These deposits represent unweathered Holocene (uHD) dune deposits. Weathered dune deposits are divided into two types: relatively uncemented dune deposits and cemented dune deposits. Absolute dating of representative dune deposit types in the study area, using TL and ${ }^{14} \mathrm{C}$ methods (see Section 4.5 below), demonstrate that the weathered uncemented dune deposits are Holocene in age and the weathered cemented dune deposits are late-Pleistocene in age (Figures 6 and 7). For purposes of field mapping, the following criteria were used to discriminate between the three dune deposit types as follows; 1) unweathered Holocene dune deposits (uHD) of $\geq 2.0 \mathrm{~m}$ layer thickness, which consist of fine/medium well-sorted sand with no pebbles, and unconfined shear strength $\leq 1 \mathrm{~kg} \mathrm{~cm}^{-2}$ ), 2) weathered Holocene dune deposits (wHD) $\geq 2.0 \mathrm{~m}$ layer thickness, which consist of fine/medium well-sorted sand with no pebbles, sand grain reddening (FeOx staining) to hues of 7.5YR or 10YR, and unconfined shear strength $1.0-2.0 \mathrm{~kg} \mathrm{~cm}^{-2}$, and 3) cemented Pleistocene dune deposits (PD) $\geq 2.0 \mathrm{~m}$ layer thickness, which consist of fine/medium well-sorted sand with no pebbles, which are cemented with unconfined shear strength of $\geq 2.5 \mathrm{~kg} \mathrm{~cm}^{-2}$.
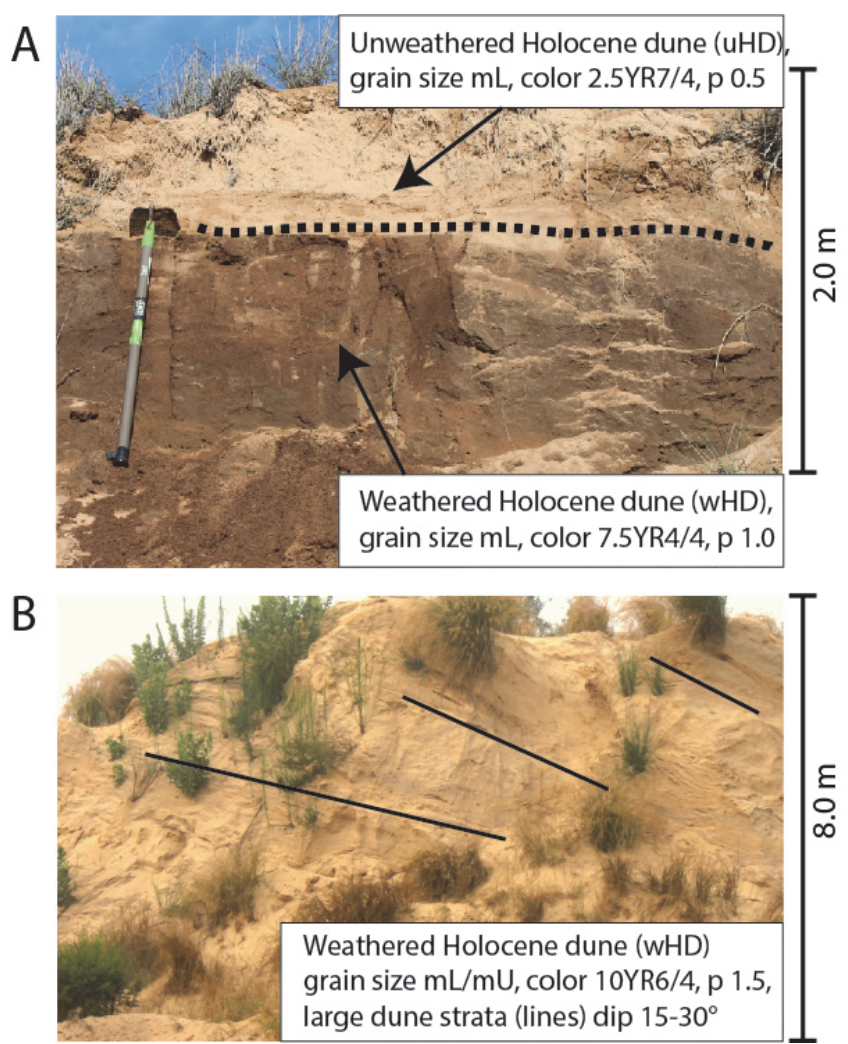

Figure 6. Representative Holocene dune sections in the study area

Part A: Contact (dotted bold line) between 1) overlying unweathered Holocene dune (uHD) deposit with dominant grain size $(\mathrm{mL})$, color $(2.5 \mathrm{YR} 7 / 4)$, and unconfined shear strength $(\mathrm{p} 0.5)$ and 2$)$ underlying weathered Holocene dune (wHD) deposit with A/Bw soil horizon color 7.5YR 4/4 and unconfined shear strength (p 1.0). 
Photo is from site S34, near the south end of the Santa Maria dune sheet. Part B: Weathered Holocene dune (wHD) deposit with unconfined shear strength (p 1.5) and large dune strata that dip 15-30 to the northwest. Photo is from a sand quarry at site S20, near the middle of the Santa Maria dune sheet. See Figure 8 for site locations.
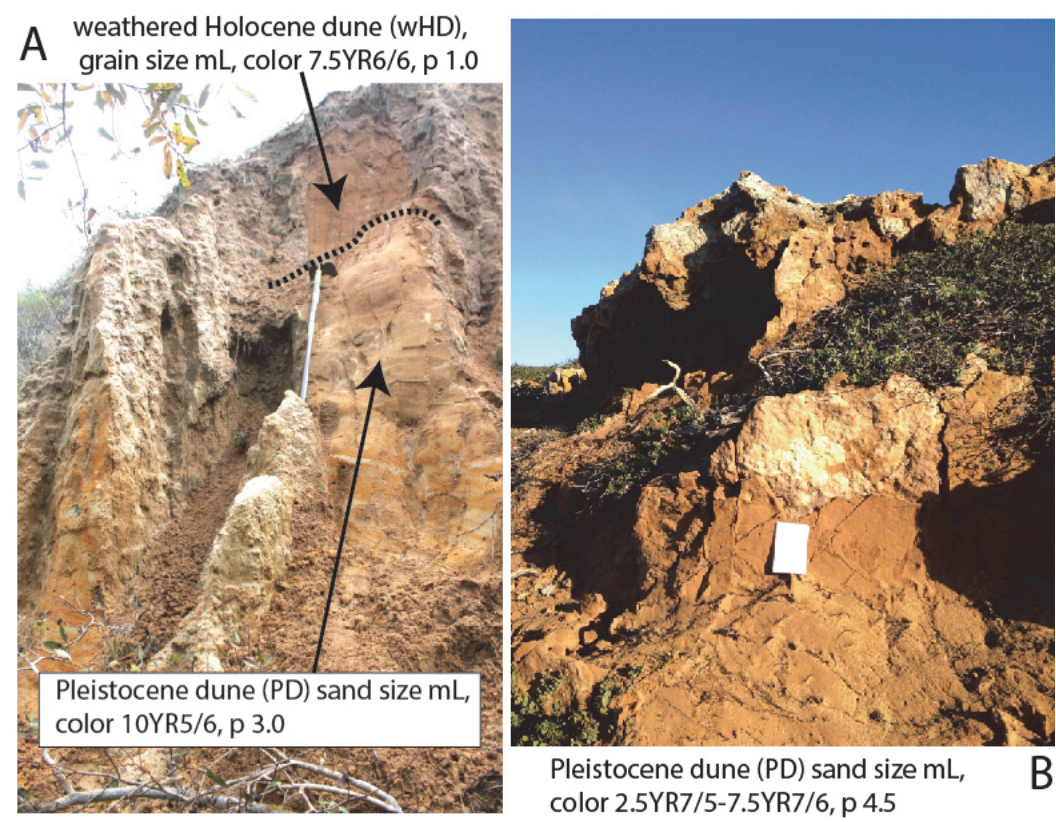

Pleistocene dune (PD) sand size $\mathrm{mL}$, color 2.5YR7/5-7.5YR7/6, p 4.5

Figure 7. Representative Pleistocene dune sections in the study area

Part A: Contact (dotted bold line) between 1) overlying weathered Holocene dune (wHD) deposit with dominant grain size $(\mathrm{mL})$, color (7.5YR6/6), and unconfined shear strength (p 1.0) and 2) underlying latest-Pleistocene dune (PD) deposit, estimated $23-29 \mathrm{ka}$ in age from Orme (1992), with unconfined shear strength (p 3.0). Hole handle is $1.0 \mathrm{~m}$ in length. Photo is from site S34. Part B: Oldest late-Pleistocene dune (PD) or 'dissected' Pleistocene dunes of Orme (1992), with variable podzolic-leaching soil colors (Birkeland, 1999), ranging from $2.5 \mathrm{YR} 7 / 5$ light gray to $7.5 \mathrm{YR} 7 / 6$ reddish Fe-stained, and unconfined shear strength ( $\mathrm{p} \geq 4.5)$. White note book is $0.2 \mathrm{~m}$ in length. Photo is from site S38. See Figure 8 for site locations.

In this article, the non-dune late-Pleistocene or cemented sandy deposits, with unconfined shear strength $\geq 2.5 \mathrm{~kg}$ $\mathrm{cm}^{-2}$, are divided into 1) Pleistocene alluvium (PA), with angular/subangular gravel, as developed in river flood plain, gully fill or sheet wash settings and 2) Pleistocene beach deposits (PB), with rounded/subrounded gravel, as developed in uplifted marine terrace/platform settings. Remobilized 'Holocene' paleo-dune deposits (rHD) occur in discontinuous subaerial layers above some late-Pleistocene alluvial deposits and late-Pleistocene dune deposits. They likely developed episodically as winnowed hummocks, runoff sheet wash fans, and/or burrowed surface layers. The remobilized dune deposits (rHD) are of agricultural and archaeological interests, but they do not directly represent episodes of marine sand supply, so they are not addressed in greater detail in this article.

\subsection{Extent and thickness of migratory paleo-dune deposits in the Santa Maria dune sheet}

The landward extent and thickness of migratory dune deposits in the Santa Maria dune sheet were mapped on the bases of modern satellite and Lidar images and 43 morphostratigraphic sections (Figure 8; Table 4). Non-vegetated or sparsely vegetated parabolic dunes with unweathered subsurface dune deposits extend to distances of $0.5-5 \mathrm{~km}$ landward of the present shoreline with increasing width from north to south. The unweathered Holocene dune (uHD) deposits reach substantial thicknesses (10-20 m thickness) at sites S8, S19, F5, TM, and S28 in the Guadalupe dune fields (Figure 9). Large transverse dunes (5-10 m dune trough-crest heights) ramp up the south-westernmost slope of the Point Sal Ridge (Figure 3A), reaching elevations of 135$145 \mathrm{~m}$ at sites S33 and S34. The increasing widths and thicknesses of the unweathered Holocene dune deposits in the southern half of the Santa Maria dune sheet are consistent with southerly net littoral transport in the area during latest-Holocene time (Peterson et al., 2009). Over-steepened eolian sand ramps extend from the modern beach to bluff tops, reaching 150-160 m elevation at sites S35 and S38 between Mussel Rock and Point Sal, at the southern end of the Santa Maria dune sheet. 


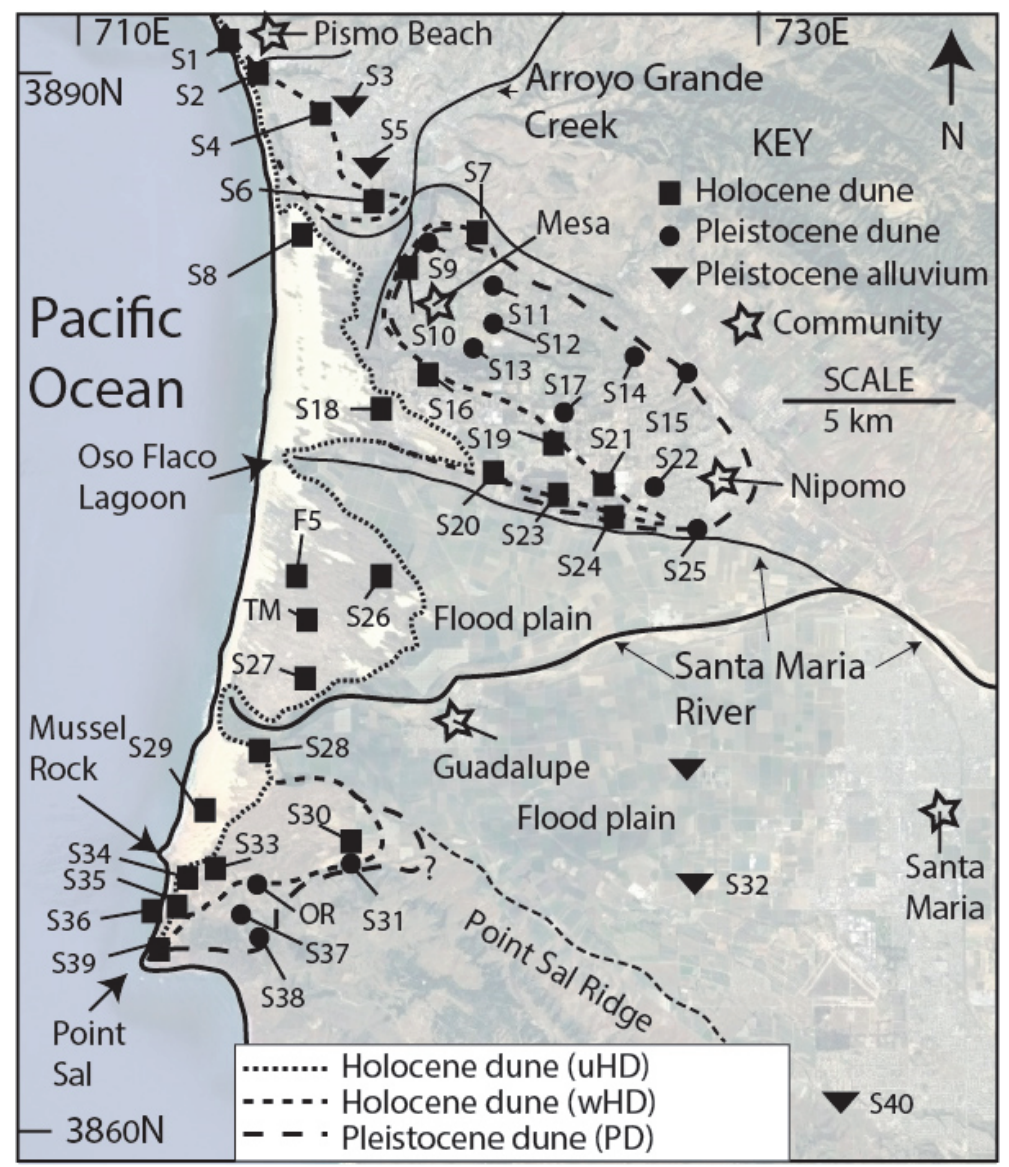

Figure 8. Map of morphostratigraphic sections in the Santa Maria dune sheet

Morphostratigraphic sites (S) (this article) and selected subsurface section sites, including OR (Orme, 1992) and TM and F5 (Knott and Eley, 2006) are shown in the Santa Maria dune sheet. Near surface deposits are designated Holocene dune (black square) and Pleistocene dune (black circle), Pleistocene beach platform (black rectangle) and Pleistocene alluvium (black inverted triangle). Unweathered (recently active) Holocene dunes (uHD) are discriminated from weathered (stabilized) Holocene dunes (wHD) and cemented Pleistocene dunes (PD).

Table 4. Summary of deposits in morphostratigraphic sections of the Santa Maria dune sheet

\begin{tabular}{|c|c|c|c|c|c|c|c|}
\hline $\begin{array}{l}\text { Site } \\
\text { no. }\end{array}$ & $\begin{array}{l}\text { Unit } 1 \\
\text { depth (m) }\end{array}$ & $\begin{array}{l}\text { Unit } 2 \\
\text { depth }(\mathrm{m})\end{array}$ & $\begin{array}{l}\text { Unit } 3 \\
\text { depth (m) }\end{array}$ & $\begin{array}{l}\text { Site } \\
\text { no. }\end{array}$ & $\begin{array}{l}\text { Unit } 1 \\
\text { depth (m) }\end{array}$ & $\begin{array}{l}\text { Unit } 2 \\
\text { depth (m) }\end{array}$ & $\begin{array}{l}\text { Unit } 3 \text { depth } \\
\text { (m) }\end{array}$ \\
\hline S1 & $\mathbf{u H D}(0-1.2)$ & wHD(1.2-7.0) & $\mathrm{HA}(7-11)$ & S22 & $\mathrm{PD}(0-5.0)$ & & \\
\hline $\mathrm{S} 2$ & wHD(0-7.0) & $\operatorname{PA}(7.0-8)$ & & S23 & wHD $(0-15)$ & $\mathbf{P D}(15-65)$ & $\mathrm{PA}(65-68)$ \\
\hline $\mathrm{S} 3$ & $\mathrm{PA}(0-3.0)$ & & & S24 & wHD(0-6) & PD(6-57) & $\mathrm{PA}(57-59)$ \\
\hline S4 & $\mathbf{w H D}(0-8.5)$ & $\mathrm{PA}(8.5-10)$ & & S25 & $\mathrm{rHD}(0-1.0$ & PD(1.0-29) & $\mathrm{PA}(29-30)$ \\
\hline S5 & $\mathrm{PA}(0-3.0)$ & & & F5 & $\mathbf{u H D}(0-22.1)$ & $\mathrm{HA}(22.1-25)$ & \\
\hline S6 & $\mathbf{w H D}(0-3.5)$ & $\mathrm{PA}(3.5-5.0)$ & & S26 & uHD(0-14) & HA(14-15) & \\
\hline S7 & $\mathbf{w H D}(0-15)$ & $\mathrm{BR}(15-25)$ & & $\mathrm{TM}$ & $\mathbf{u H D}(0-22.9)$ & $\mathrm{HA}(23-28)$ & \\
\hline S8 & $\mathbf{u H D}(0-12)$ & $\mathrm{HA}(12.0-13)$ & & S27 & uHD $(0-35)$ & $\mathrm{HA}(35-36)$ & \\
\hline S9 & $\mathbf{P D}(0-40.0)$ & $\mathrm{PA}(40.0-43)$ & & S28 & uHD $(0-19.0)$ & $\mathrm{HA}(19-20)$ & \\
\hline S10 & $w H D(0-2.0)$ & $\mathbf{P D}(2.0-28)$ & $\mathrm{PA}(28-29)$ & S29 & uHD $(0-3.0)$ & $\mathrm{wHD}(3.0-5.0)$ & \\
\hline S11 & $\mathbf{P D}(0-25)$ & $\mathrm{PA}(25-27)$ & & S30 & wHD $(0-5.5)$ & $\mathrm{PD}(5.5-6.5)$ & \\
\hline $\mathrm{S} 12$ & $\mathbf{P D}(0-55)$ & $\mathrm{PA}(55-57)$ & & S31 & wHD $(0-2.0)$ & $\mathbf{P D}(2.0-22.5)$ & $\mathrm{PA}(23-25)$ \\
\hline S13 & $\mathrm{rHD}(0-1.5$ & $\operatorname{PD}(1.5-43)$ & $\mathrm{PA}(43-44)$ & S32 & $\mathrm{rHD}(0-1.0)$ & $\mathrm{PA}(1.0-3.0)$ & \\
\hline S14 & $\operatorname{rHD}(0-1.0)$ & $\mathbf{P D}(1.00-8.5)$ & $\operatorname{PA}(8.5-9)$ & S33 & $\mathbf{u H D}(0-8.0)$ & wHD $(8.0-24)$ & $\mathbf{P D}(24-34)$ \\
\hline S15 & $\mathbf{P D}(0-5.0)$ & $\mathrm{PA}(5.0-6)$ & & S34 & $\mathbf{u H D}(0-10.0)$ & wHD(10-23) & $\mathbf{P D}(23-34)$ \\
\hline
\end{tabular}




\begin{tabular}{|c|c|c|c|c|c|c|c|}
\hline S16 & $\mathbf{w H D}(0-3.8)$ & $\mathrm{PD}(3.8-5.0)$ & & OR & PA(10-22) & $\mathrm{PD}(22-26)$ & PA(26-39) \\
\hline S17 & $\mathrm{PD}(0-4.0)$ & & \multirow{6}{*}{$\mathrm{HA}(30-35)$} & S35 & $\mathbf{u H D}(0-2.0)$ & $\mathrm{wHD}(2.0-4.0)$ & \\
\hline $\mathrm{S} 18$ & $\mathbf{u H D}(0-10)$ & wHD(10-30) & & S36 & $\mathbf{u H D}(0-10)$ & wHD(10-40) & $\mathrm{PA}(40-45)$ \\
\hline S19 & $\mathbf{w H D}(0-2.5)$ & $\mathrm{PD}(2.5-3.5)$ & & S37 & $\mathbf{P D}(0-13)$ & BR(13-15) & \\
\hline S20 & wHD $(0-15)$ & $\mathrm{PD}(15-18)$ & & S38 & $\mathbf{P D}(0-15)$ & $\mathrm{BR}(15-20)$ & \\
\hline \multirow[t]{2}{*}{ S21 } & wHD $(0-4.0)$ & $\mathrm{PD}(4.0-7.0)$ & & S39 & $\mathbf{u H D}(0-5.0)$ & wHD(7.0-9.5) & \\
\hline & & & & S40 & $\mathrm{rHD}(0-3.0)$ & $\mathrm{pA}(3.0-7.0)$ & \\
\hline
\end{tabular}

Notes: Morphostratigraphic section site and letter/number code (Table 2) with units (deposit types) in depth subsurface (m). Deposit types include unweathered Holocene dune sand (uHD), weathered Holocene dune sand (wHD), remobilized Holocene dune (rHD), Holocene alluvium (HA), Pleistocene dune (PD), Pleistocene alluvium (PA), Pleistocene Beach (PB), and bedrock (BR). Section S1 was extended (3.5-11.0 m depth subsurface) using geotechnical data from borehole \#5 log (Earth Systems Pacific, 2005). Water well data were used to extend section S4 from 3.5 to $10 \mathrm{~m}$ depth and to extend section S12 from $2.5 \mathrm{~m}$ to $55 \mathrm{~m}$ depth. Several previously published gully-cut sections and associated ${ }^{14} \mathrm{C}$ ages (Orme, 1992) were combined to form the composite OR section. Only complete paleo-dune deposit units (bold type) were used for dune sheet volume estimates.

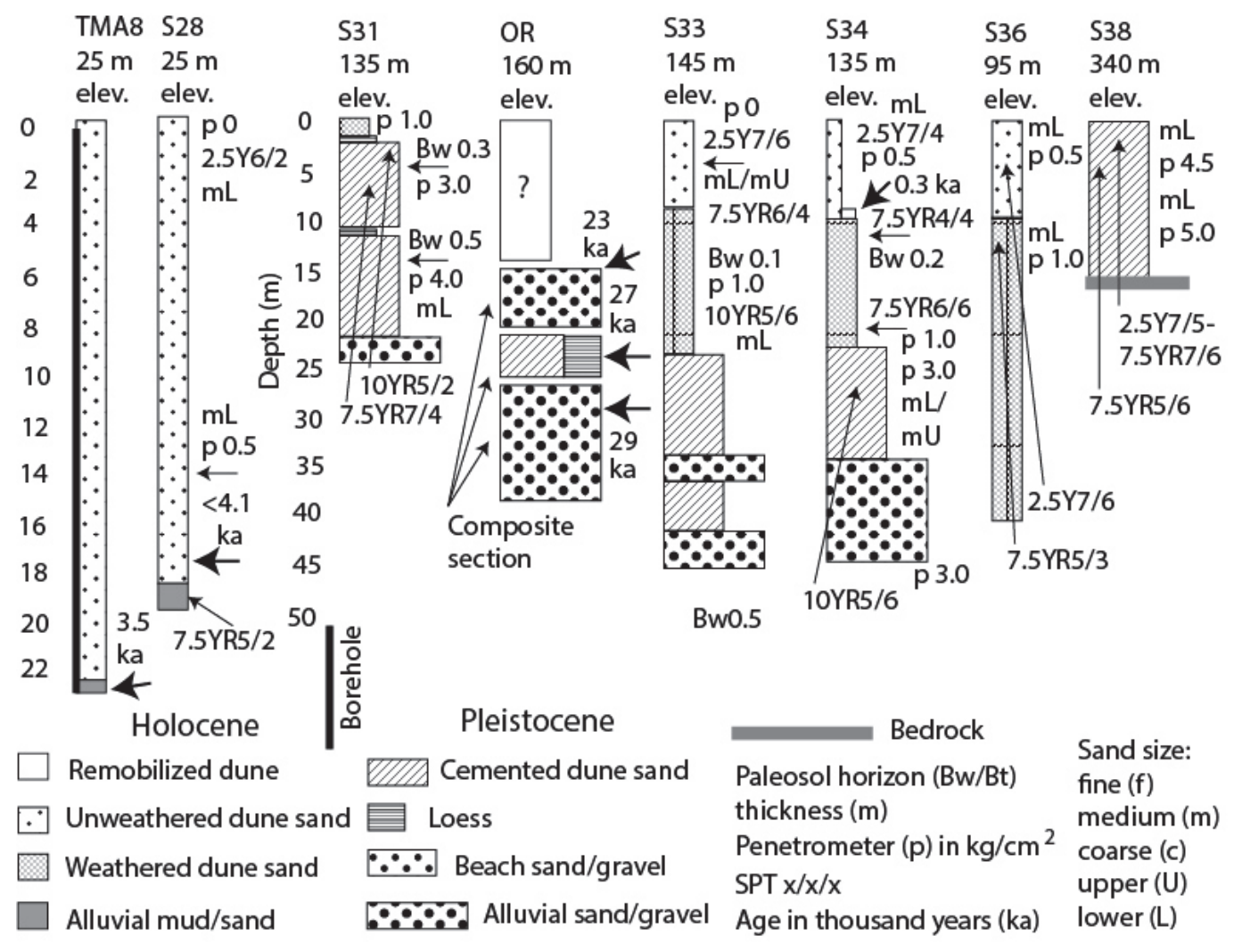

Figure 9. Representative morphostratigraphic sections from the Santa Maria dune sheet

Two previously published sections with associated radiocarbon dates (Orme, 1992) are combined here to form the composite section OR. See Figure 8 for core site locations.

The landward extents of weathered Holocene dune deposits are established by 1) remnant parabolic or transverse dune topography and 2) morphostratigraphic sections (Figure 8; Table 4). The greatest landward extents ( $\sim 11 \mathrm{~km})$ of the weathered Holocene dune (wHD) deposits occur near the middle of the Santa Maria dune sheet at sites S21 and S24. Remnant parabolic dune features and deposits reach elevations of $90-115 \mathrm{~m}$ at sites S20, S23, and S24 along the north side of the Santa Maria River valley where they reach thicknesses of 6-15 m (Figure 6B). The weathered Holocene dunes are sharply truncated to the south by the Santa Maria River flood plain, thereby demonstrating that the emplacement of the weathered Holocene dunes pre-dated latest-Holocene cut-and-fill of the Santa Maria floodplain. Weathered Holocene dune deposits underlie the unweathered Holocene dunes that 
ramp up the Point Sal Ridge, such as exposed in a large gully cut at sites S33 and S34 (Figure 6A). The weathered Holocene dunes extend well landward of the active dunes to reach S30 located $\sim 5.5 \mathrm{~km}$ from the coastline on the eastern flank of Point Sal Ridge at an elevation of $125 \mathrm{~m}$ (Table 2). At the opposite (north) end of the Santa Maria dune sheet, the weathered Holocene dune deposits only reach modest elevations of $\sim 20 \mathrm{~m}$, as at sites S4 and S6, where they are mapped to $\sim 2-2.5 \mathrm{~km}$ landward of the present shoreline. The weathered Holocene dunes at sites S4 and S6, at the northernmost end of the Santa Maria dune sheet, overlie a seaward sloping apron of latest-Pleistocene or earliest-Holocene pebbly sand alluvium, which possibly derived from stream-reworked paleo-dune deposits. Weathered Holocene dune deposits of variable thickness and width also rim the western edge of the Mesa bluffs, located east of an abandoned channel of the Arroyo Grande Creek.

Late-Pleistocene dune deposits (PD) are extensive in the Santa Maria dune sheet, where they extend to landward distances of $\sim 15 \mathrm{~km}$ and $\sim 7 \mathrm{~km}$, respectively, on the north and south sides of the Santa Maria River Valley (Figure 8; Table 4). The late-Pleistocene dune deposits on the north side of the Santa Maria River Valley form a broad ridge (Mesa-Nipomo sand ridge) reaching up to $130 \mathrm{~m}$ in elevation between the bounding Santa Maria River and Arroyo Grande tributary alluvial valleys (Table 2). Measured sections and/or water well records at sites, S9, S10, S12, S13, S23, S24, and S25 establish maximum thicknesses ( 30-60 m) of late-Pleistocene dune deposits overlying late-Pleistocene alluvium (Figure 10). South of the Santa Maria River Valley the latest-Pleistocene dune deposits underlie the weathered Holocene dunes, as at sites S33 and S34 (Figures 7A and 9) on the north slope of Point Sal Ridge. Near that locality, latest-Pleistocene dune deposits and reworked dune/alluvium deposits (composite site OR in Figure 9) are dated to 23-29 ka (Orme, 1992). Much older late-Pleistocene dune deposits reach $\sim 13-15 \mathrm{~m}$ in thickness at sites S37 and 38, respectively, located at $260 \mathrm{~m}$ and $340 \mathrm{~m}$ elevation on the eastern crest of the Point Sal Ridge (Figure 7B), where they were referred to as 'dissected paleo-dunes' by Orme (1992).

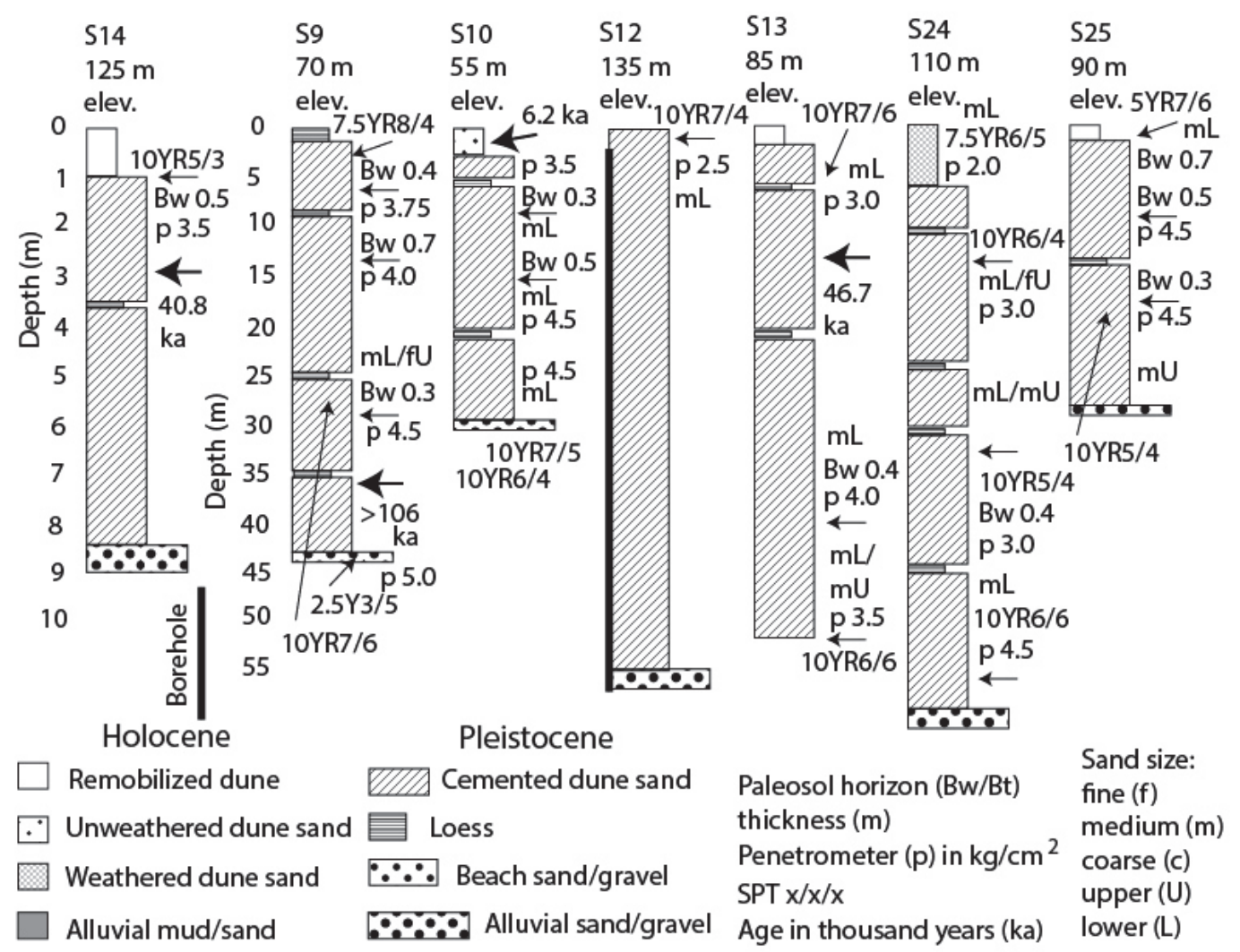

Figure 10. Representative morphostratigraphic sections from the Santa Maria dune sheet

Water well logs were used to confirm the vertical depths of paleo-dune deposits in S4 and S12. Steep slope traverses in river valley sides were used to measure sections S9, S10, S13, S23, S24 and S25, as corrected for vertical depths. 


\subsection{Extent and Thickness of Migratory Paleo-Dune Deposits in the Vandenberg Dune Sheet}

The landward extent and thickness of migratory dune deposits in the Vandenberg dune sheet were mapped on the bases of modern satellite and Lidar images and 47 morphostratigraphic sections (Figure 11; Table 5). Non-vegetated and sparsely vegetated parabolic dunes with unweathered subsurface dune deposits extend to distances of 1-4 km landward of the present shoreline located north of Purisima Point in the Vandenberg dune sheet. The recently active or unweathered Holocene dune (uHD) deposits range from 2-9 m thickness in auger and geotechnical boreholes, such as at sites V7, V8, V9, V1l, and V26 (Figure 12). The landward extents of the recently active dune fields diminish to less than $1.0 \mathrm{~km}$ width south of the minor Purisima Point headland, and to less than $0.5 \mathrm{~km}$ width south of the Santa Ynez River. The localized accumulation of unweathered Holocene dune deposits north of the Purisima Point headland indicates partial interruption of net southerly littoral transport in the northern part of the Vandenberg dune sheet. However, the general lack of unweathered Holocene dune deposits in the southernmost part of the Vandenberg dune sheet, south of site V42, suggests an ongoing loss of littoral sand around Point Pednerales to the south, in latest-Holocene time.

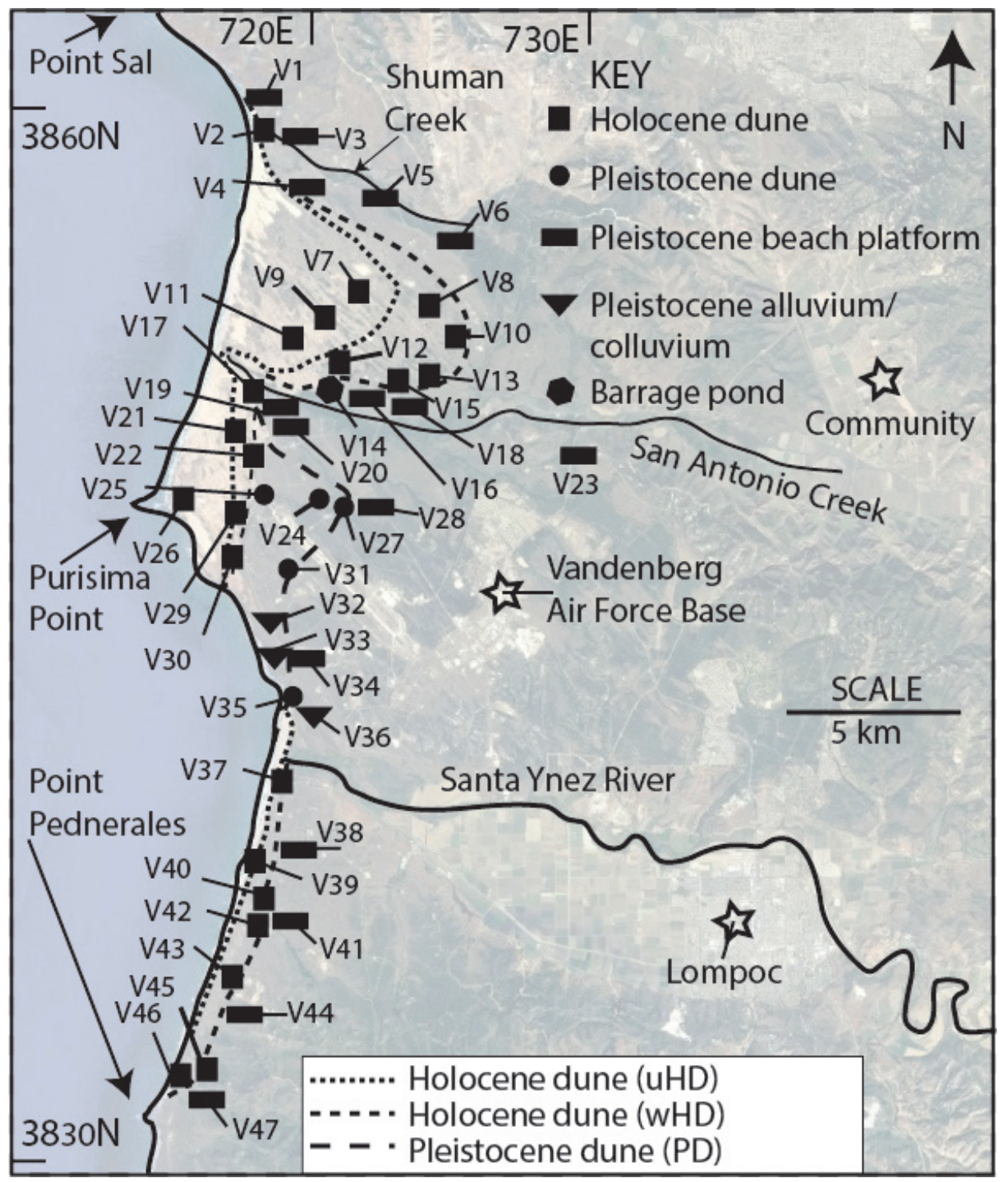

Figure 11. Map of morphostratigraphic sections (V) in the Vandenberg dune sheet

Near surface deposits are designated Holocene dune (black square) and Pleistocene dune (black circle), Pleistocene beach platform (black rectangle) and Pleistocene alluvium (black inverted triangle). Unweathered (recently active) Holocene dune deposits (uHD) are discriminated from weathered (stabilized) Holocene dune deposits (wHD) and cemented Pleistocene dune deposits (PD). 
Table 5. Summary of deposits in morphostratigraphic sections of the Vandenberg dune sheet

\begin{tabular}{|c|c|c|c|c|c|c|c|}
\hline $\begin{array}{l}\text { Site } \\
\text { no. }\end{array}$ & $\begin{array}{l}\text { Unit } 1 \\
\text { depth (m) }\end{array}$ & $\begin{array}{l}\text { Unit } 2 \\
\text { depth (m) }\end{array}$ & $\begin{array}{l}\text { Unit } 3 \text { depth } \\
(\mathrm{m})\end{array}$ & $\begin{array}{l}\text { Site } \\
\text { no. }\end{array}$ & $\begin{array}{l}\text { Unit } 1 \\
\text { depth (m) }\end{array}$ & $\begin{array}{l}\text { Unit } 2 \\
\text { depth (m) }\end{array}$ & $\begin{array}{l}\text { Unit } 3 \text { depth } \\
\text { (m) }\end{array}$ \\
\hline V1 & $\mathrm{PB}(0-0.5)$ & & & V25 & $\mathrm{rHD}(0-1.0$ & $\mathrm{PB}(1.0-3.0)$ & $\mathrm{BR}(3-5)$ \\
\hline V2 & $\mathbf{u H D}(0-2.0)$ & $\mathrm{PB}(2.0-3.5)$ & & V26 & $\mathbf{u H D}(0-4.8)$ & wHD(4.8-17) & PD(17-24) \\
\hline V3 & $\mathrm{rHD}(0-0.5)$ & $\mathrm{PB}(0.5-2.0)$ & & V27 & $\mathbf{P D}(0-3.0)$ & PB(3.0-5.0) & $\mathrm{BR}(5-6)$ \\
\hline V4 & $\mathrm{PB}(0-0.7)$ & $\mathrm{BR}(0.1-1.7)$ & & V28 & $\mathrm{rHD}(0-2.0)$ & $\mathbf{P D}(2.0-2.5)$ & $\mathrm{PB}(2.5-3)$ \\
\hline V5 & $\mathrm{PB}(0-3.0)$ & & & V29 & $\mathbf{u H D}(0-4.0)$ & $\mathbf{w H D}(4.0-9.8)$ & $\mathbf{P D}(9.8-12)$ \\
\hline V6 & $\mathrm{rHD}(0-1.00$ & $\mathrm{PB}(1.0-2.0)$ & & V30 & $\mathbf{u H D}(0-3.0)$ & wHD(3.0-7.6) & $\mathbf{P D}(7.6-12)$ \\
\hline V7 & $\mathbf{u H D}(0-7.4)$ & wHD(7.4-17) & PA(17-18) & V31 & $\mathrm{rHD}(0-0.5)$ & $\mathbf{P D}(0.5-1.5)$ & \\
\hline V8 & $\mathbf{w H D}(0-5.0)$ & PA(5.0-10) & $\mathrm{BR}(10-11)$ & V32 & $\mathrm{PA}(0-2.0)$ & & \\
\hline V9 & $\mathbf{u H D}(0-8.4)$ & wHD(8.4-17) & $\mathrm{PA}(17-18)$ & V33 & $\mathrm{PA}(0-3.0)$ & $\mathrm{BR}(3.0)$ & \\
\hline V10 & $\mathbf{w H D}(0-4.0)$ & PA(4.0-9.0) & & V34 & $\mathrm{PA}(0-2.0)$ & $\mathrm{PB}(2.0-4.0)$ & $\mathrm{BR}(4-5)$ \\
\hline V11 & uHD(0-9.0) & $\mathbf{w H D}(9.0-21)$ & $\mathrm{BR}(21-22)$ & V35 & $\mathrm{PA}(0-4.0)$ & $\mathbf{P D}(4.0-5.0)$ & $\mathrm{PB}(5-6)$ \\
\hline V12 & wHD(0-13) & PA(13-16) & $\mathrm{BR}(16-17)$ & V36 & $\mathrm{rHD}(0-0.5)$ & $\mathrm{PA}(0.5-1.5)$ & \\
\hline V13 & wHD $(0-5.0)$ & $\mathrm{PA}(5.0-7.0)$ & & V37 & $\mathbf{w H D}(0-3.0)$ & $\mathrm{PB}(3.0-5.0)$ & \\
\hline V14 & Hmud (2-7) & & & V38 & $\mathrm{PB}(0-2.0)$ & & \\
\hline V15 & $\mathbf{w H D}(0-5.0)$ & $\mathrm{PA}(5.0-7.0)$ & & V39 & uHD $(0-8.8)$ & wHD(8.0-18) & PA(18-25) \\
\hline V16 & $\mathrm{rHD}(0-1.0)$ & $\mathrm{PB}(1.0-1.5)$ & & V40 & $\mathbf{w H D}(0-21)$ & PA(21-30) & $\mathrm{PB}(30-40)$ \\
\hline V17 & $\mathrm{wHD}(0-4.0)$ & & & V41 & $\mathrm{PB}(0-3.5)$ & & \\
\hline V18 & $\mathrm{rHD}(0-1.0$ & $\mathrm{PB}(1.0-1.5)$ & & V42 & $\mathbf{u H D}(0-1.0)$ & $\mathbf{w H D}(1-20)$ & $\mathbf{P D}(20-23)$ \\
\hline V19 & $\mathrm{rHD}(0-0.5)$ & $\mathrm{PB}(0.5-1.2)$ & $\mathrm{BR}(1.2-3)$ & V43 & $\mathbf{u H D}(0-1.0)$ & wHD(1-55) & $\mathrm{PA}(55-60)$ \\
\hline V20 & rHD0-0.5) & $\mathrm{PB}(0.5-1.5)$ & $\mathrm{BR}(1.5-2)$ & V44 & $\mathrm{PB}(0-1.0)$ & & \\
\hline V21 & $\mathbf{u H D}(0-5.0)$ & $\mathbf{w H D}(5.0-10)$ & $\mathrm{BR}(10-11)$ & V45 & $\mathbf{u H D}(0-1.0)$ & $\mathbf{w H D}(1-30)$ & PA(30-49) \\
\hline V22 & $\mathbf{w H D}(0-3.0)$ & $\mathbf{P D}(3.0-6.0)$ & $\mathrm{PB}(6-9)$ & V46 & $\mathbf{u H D}(0-1.0)$ & wHD(1-43.0) & PD(43-48) \\
\hline V23 & $\mathbf{P D}(0-3.0)$ & $\mathrm{PB}(3.0-5.0)$ & & V47 & $\mathrm{PB}(0-3.0)$ & & \\
\hline V24 & $\mathrm{rHD}(0-0.3)$ & $\mathbf{P D}(0.3-4.0)$ & $\mathrm{PB}(4-5)$ & & & & \\
\hline
\end{tabular}

Notes: Morphostratigraphic section site and letter/number code (Table 2) with units (deposit types) in depth subsurface (m). Deposit types include unweathered Holocene dune sand (uHD), weathered Holocene dune sand (wHD), remobilized Holocene dune (rHD), Holocene alluvium (HA), Pleistocene dune (PD), Pleistocene alluvium (PA), Pleistocene Beach (PB), and bedrock (BR). One barrage pond site (V14) contains Holocene mud (Hmud) at 2-6.6 m depth subsurface (Anderson et al., 2015). Geotechnical borehole records (VAFB, 2016) and corresponding extensions of morphostratigraphic sections are as follows: V7 borehole 31MW8 and 31MW11 at 7-18 m depth subsurface, V8 boreholes 54MW and 27MW3 at 5-11 m depth, V9 boreholes $31 \mathrm{MW} 8$ and $31 \mathrm{MW} 10$ at 7-18 m depth, V10 borehole 27MW3 at 4-9 m depth, V11 borehole 15MW8 at 12-22 $\mathrm{m}$ depth, V12 borehole 34MW1 at 6-16 m depth, V21 borehole 13MW5 at 5-11 m depth, V26 borehole 40MW2 at 7-24 m depth, V29 borehole 25MW5 at 5-14 m depth, V30 borehole 33J-B6 at 3-12 m depth, and V43 borehole 9MW10 at 6-20 m depth. Previously reported sea-cliff stratigraphic sections (Gray, 2004) were also used to extend some morphostratigraphic profiles as follows: V26 Purisima Point section $+3-10 \mathrm{~m}$ elev., V40 and V42 Bear Creek traverse $+20-50$ m elev., V45 Delphy traverse +5-60 m elev., and V46 Honda Canyon traverse +3-55 $\mathrm{m}$ elev. Only complete paleo-dune deposit units (bold type) were used for dune sheet volume estimates.

Weathered Holocene dune deposits underlie the unweathered dune deposits and extend 0.5-3 km landward of the unweathered dune deposits in the northern part of the Vandenberg dune sheet (Figure 11; Table 5). The weathered Holocene dune (wHD) deposits in the Point Purisima vicinity (site S26) reach a maximum thickness of $17 \mathrm{~m}$ (Figure 12). The landward extents of the weathered Holocene dunes decrease to about $0.5 \mathrm{~km}$ distance near the south end of the Vandenberg dune sheet, but reach maximum thicknesses of $54 \mathrm{~m}$ and $42 \mathrm{~m}$, respectively, in steep eolian sand ramps (Peterson et al., 2017b) at sites V43 and V46 (Figure 13).

Late-Pleistocene dune deposits in the northern part of the Vandenberg dune sheet (Figure 11; Table 5) are very limited in landward extent $(<5 \mathrm{~km})$ and thickness $(3-7 \mathrm{~m})$, as mapped between sites V26, V24 and V27 (Figure 12). Late-Pleistocene erosion locally reduced the late-Pleistocene dune deposit thickness $(\sim 2 \mathrm{~m}$ thickness) in some sea cliff sections, as preserved under late-Pleistocene slope-wash alluvium in V35 (Figure 14a) located north of the Santa Ynez River mouth. Late-Pleistocene dune deposits south of the Santa Ynez River mouth, in the southern part of the Vandenberg dune sheet, are extremely narrow $(<0.5 \mathrm{~km}$ width $)$ and thin $(\sim 3 \mathrm{~m}$ thickness $)$ where exposed in eroded gully/sea cliff sections at sites S42 and S46 (Figure 13). 


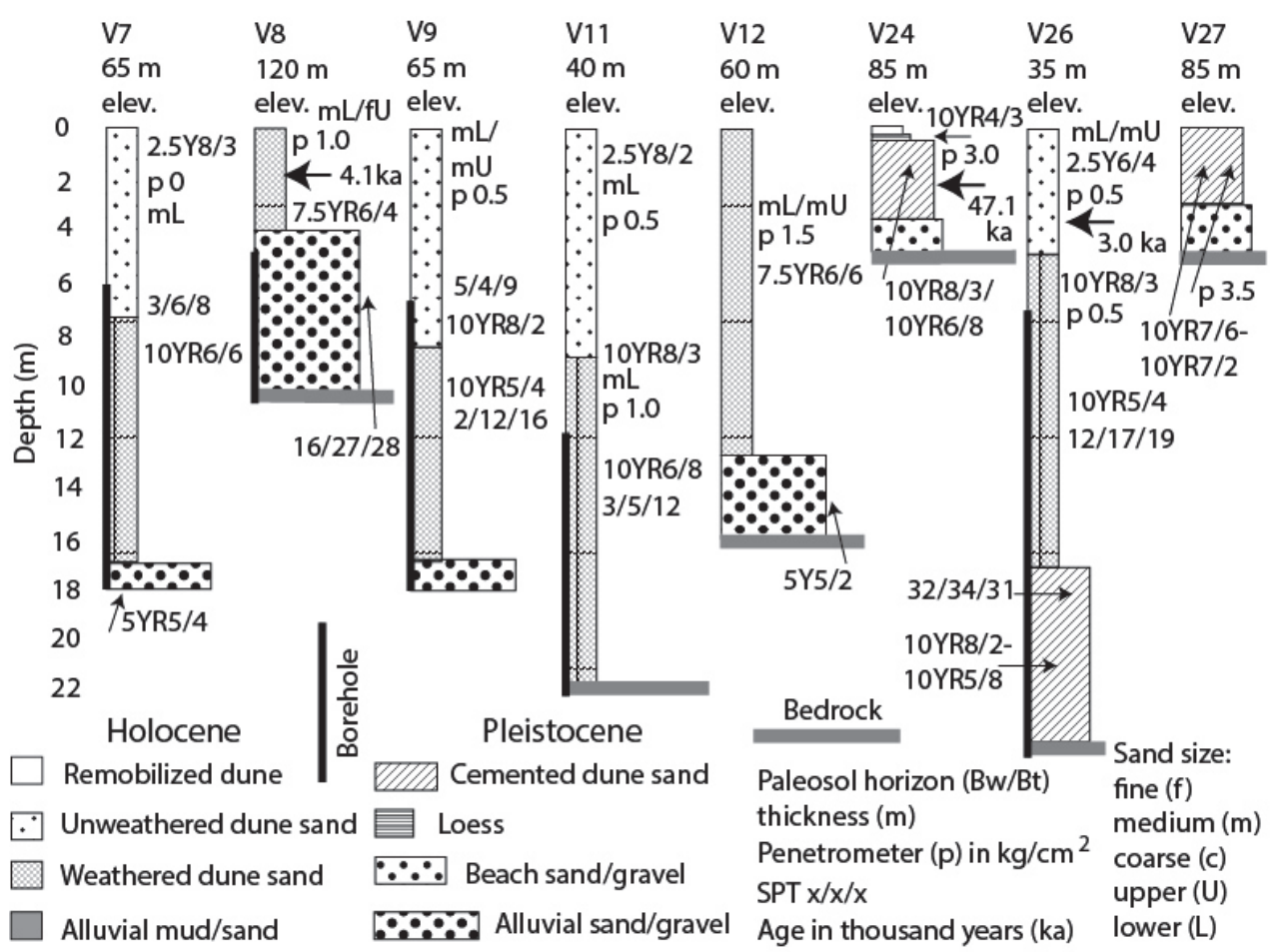

Figure 12. Representative morphostratigraphic sections are shown from the Vandenberg Dune sheet Geotechnical borehole logs were used to extend sections at sites V7, V8, V9, V1l, and V26

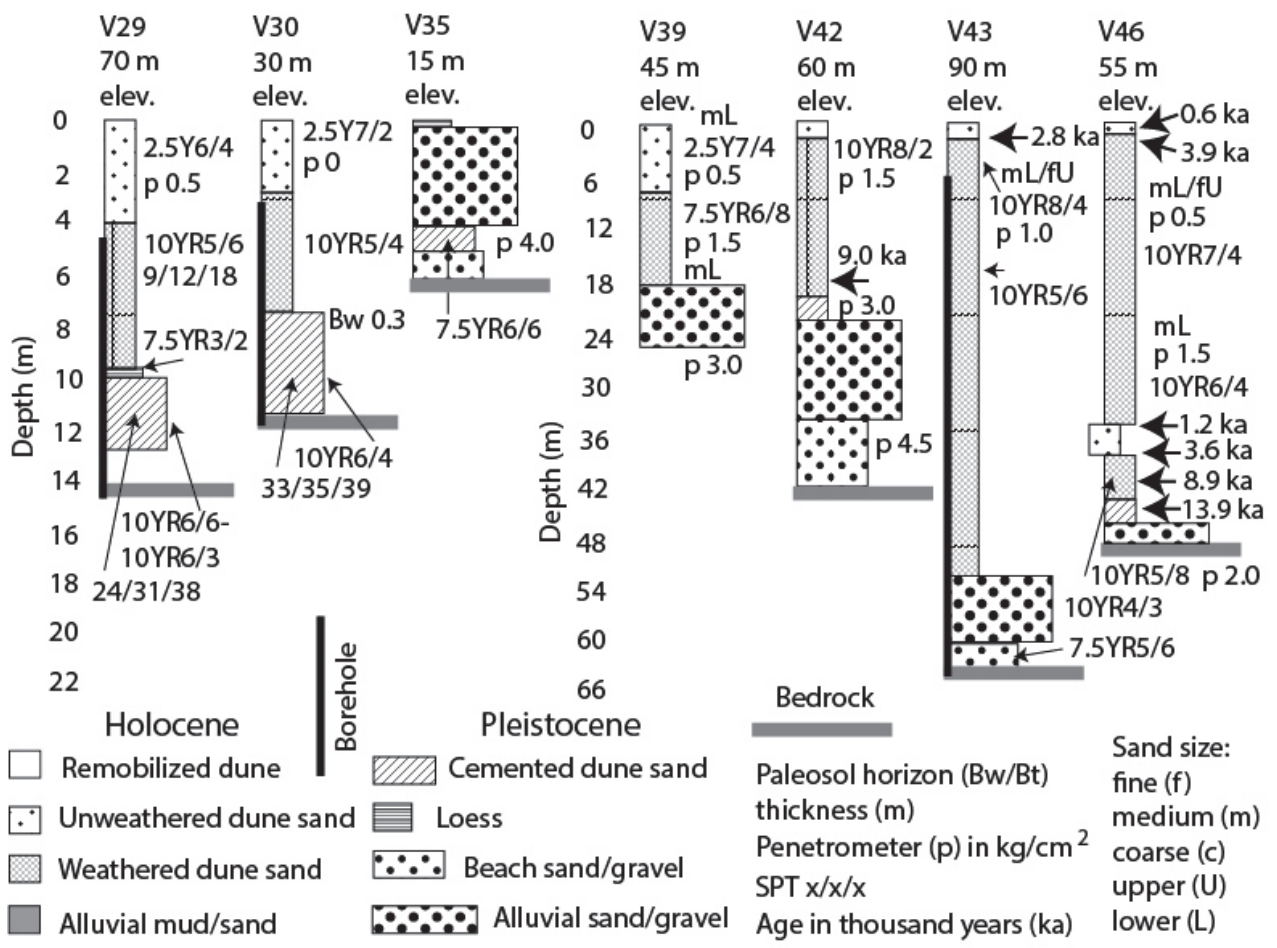

Figure 13. Representative morphostratigraphic sections are shown from the Vandenberg dune sheet Geotechnical borehole logs were used to extend sections at sites V29, V30, and V43. A short section, between 13 and $14 \mathrm{~m}$ deep, is missing from V29 due to a borehole cave-in. A small uHD inset in V46 occurs at a locally eroded and back-filled topographic bench in the sea cliff/bluff slope. Steep sea cliff traverses, corrected for vertical depth, were used to measure sections V39 and V46. Combined sea cliff and gully cut traverse were used to measure section V42 

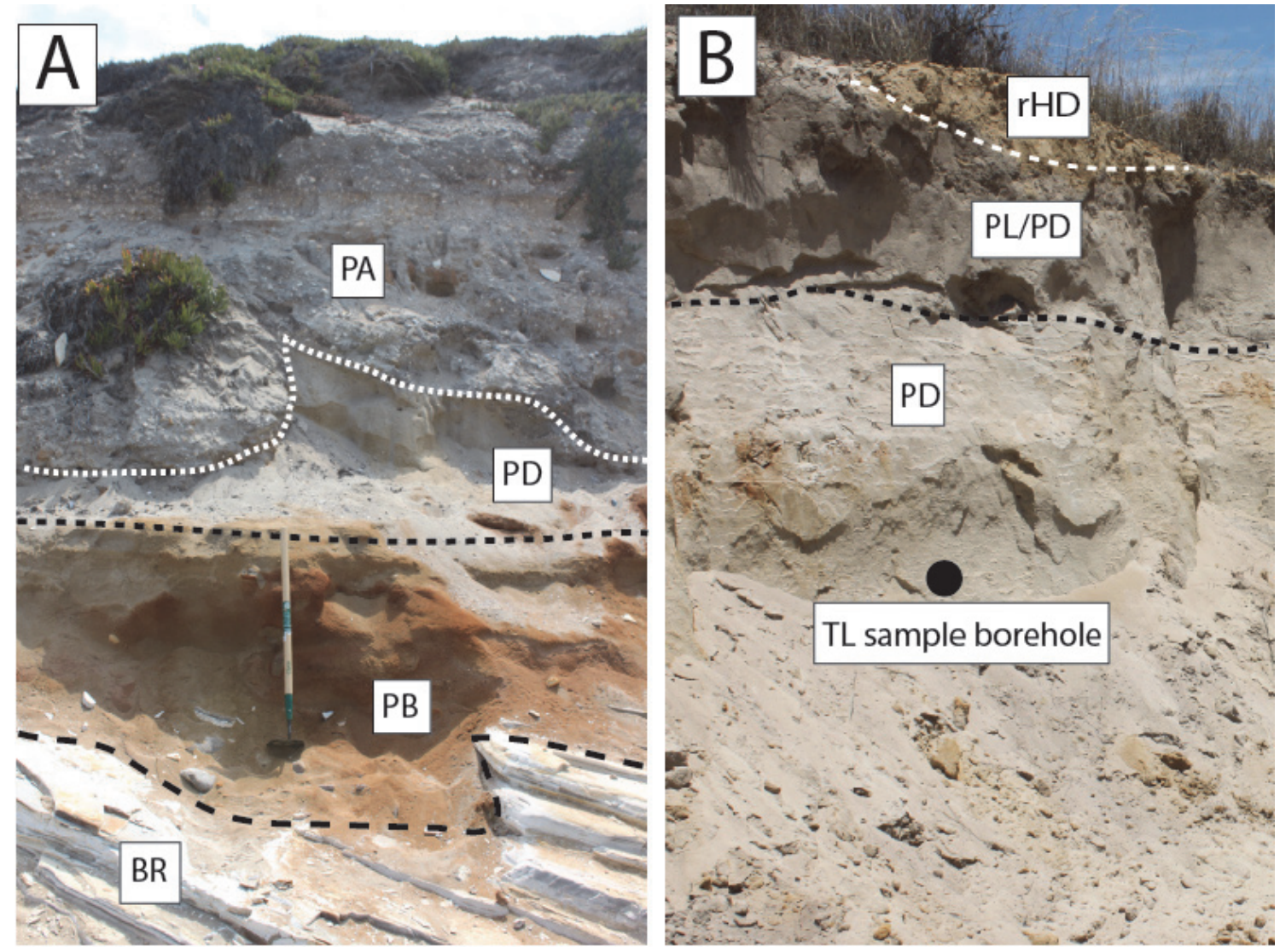

Figure 14. Representative dune sections from the Vandenberg dune sheet

Photos of two late-Pleistocene dune sections show relations of the thin Pleistocene dune sheet. Part A is from site V35 in a sea cliff cut exposure ( $7 \mathrm{~m}$ height) showing remnant Pleistocene dune deposits (PD) between overlying Pleistocene sheet wash alluvium (PA) and underlying Pleistocene beach sand deposits (PB), which are FeOx stained and include pebbles and cobbles. The beach platform bedrock (BR) is tilted Monterey (shale) formation. Part B is from site V24 in a borrow pit exposure (4 m height) of 1) a remobilized Holocene dune deposit (rHD), over 2) a Pleistocene loess/Pleistocene dune layer (PL/PD) overlying 3) a leached (10YR8/3) Pleistocene dune deposit (PD). A TL sample at $\sim 3 \mathrm{~m}$ depth (black solid circle) yielded an age of $47.1 \mathrm{ka}$ for the late-Pleistocene dune deposit.

\subsection{TL and ${ }^{14} \mathrm{C}$ Dating of Dune Deposits}

In this section, selected TL and ${ }^{14} \mathrm{C}$ sample ages from representative paleo-dune deposits in the Santa Maria and Vandenberg dune sheets (Table 6) are presented to discriminate between sand supply origins from different paleo-sea level conditions. The specific TL laboratory procedures and sample analytical data used in this study are shown in TL Laboratory Data in Supplementary Materials. TL sample ages for the late-Pleistocene dune deposits in the Santa Maria dune sheet range from $>106 \pm 21 \mathrm{ka}$ (basal paleo-dune deposit in site S9) to $40.8 \pm 4.6$ $\mathrm{ka}$ (shallow paleo-dune deposit in S14) (Figure 10). A single TL sample from the late-Pleistocene dune deposits in the northern part of the Vandenberg dune sheet (site V24) yielded an age of 47.1 $\pm 4.8 \mathrm{ka}$ (Figures 12 and 14B). Multiple coastal loess layers of marine low-stand origins (Peterson et al., 2014) in sites S9, S10, S13, and S14 are consistent with late-Pleistocene TL ages that correspond to eustatic marine low-stand conditions (Figure 4A). TL samples from the most landward weathered Holocene dune deposit in the Vandenberg dune sheet (site V8) and from the base of an unweathered Holocene dune deposit in the Santa Maria dune sheet (site S28), respectively, yielded ages of $4.1 \pm 0.6 \mathrm{ka}$, and $<4.1 \pm 0.5 \mathrm{ka}$ (Figures 9 and 12). A bounding age of $\sim 4$ ka between the weathered Holocene dune deposits and the overlying unweathered Holocene dune deposits is supported by reported ${ }^{14} \mathrm{C}$ sample ages in the study area, as shown below. 
Table 6. TL/14C ages from the Santa Maria and Vandenberg dune sheets

\begin{tabular}{|c|c|c|c|c|c|}
\hline $\begin{array}{l}\text { Dune sheet/ } \\
\text { site }\end{array}$ & $\begin{array}{l}\text { Age } \\
\text { type }\end{array}$ & $\begin{array}{l}\text { TL age }(\mathrm{ka}) \\
14 \mathrm{C} \text { age }(\mathrm{BP}) / \mathrm{Lab} \#\end{array}$ & $\begin{array}{l}\text { Deposit } \\
\text { type }\end{array}$ & $\begin{array}{l}\text { Strat. } \\
\text { Position }\end{array}$ & Ref. \\
\hline \multicolumn{6}{|l|}{ Santa Maria } \\
\hline S1 (Ca-SLO-801) & ${ }^{14} \mathrm{C}$ & $7,780 \pm 220 \mathrm{cal} \mathrm{BP} / \mathrm{UCR} 1336$ & Tivela & na & (1) \\
\hline S1 (Ca-SLO-801) & ${ }^{14} \mathrm{C}$ & $9,310 \pm 150 \mathrm{cal} \mathrm{BP} / \mathrm{UCR} 1338$ & Tivela & na & (1) \\
\hline S1 (Ca-SLO-832) & ${ }^{14} \mathrm{C}$ & $8,470 \pm$ cal BP/ B39980 & Tivela & na & (1) \\
\hline S1 (Ca-SLO-832) & ${ }^{14} \mathrm{C}$ & $8,920 \pm \mathrm{cal} \mathrm{BP} / \mathrm{B} 141923$ & Tivela & na & (1) \\
\hline S1 (Ca-SLO-1797) & ${ }^{14} \mathrm{C}$ & $9,600 \pm 60 \mathrm{cal} \mathrm{BP} / \mathrm{B} 111349$ & Tivela & na & (1) \\
\hline $\mathrm{S} 9(36 \mathrm{~m})$ & TL & $>106 \pm 21 \mathrm{ka} / \mathrm{W} 4955$ & PD & $\mathrm{B}$ & (2) \\
\hline $\mathrm{S} 10(0.6 \mathrm{~m}) \mathrm{SLO}-2357$ & ${ }^{14} \mathrm{C}$ & $6,233 \pm 150 \mathrm{cal} \mathrm{BP} / \mathrm{B} 205674$ & wHD & $\mathrm{T}$ & (2) \\
\hline $\mathrm{S} 10(2.0 \mathrm{~m}) \mathrm{SLO}-2357$ & ${ }^{14} \mathrm{C}$ & $6,204 \pm 120 \mathrm{cal} \mathrm{BP} / \mathrm{B} 205677$ & wHD & $\mathrm{B}$ & (3) \\
\hline $\mathrm{S} 13(13 \mathrm{~m})$ & TL & $46.7 \pm 2.5 \mathrm{ka} / \mathrm{W} 4956$ & PD & $\mathrm{S}$ & (2) \\
\hline $\mathrm{S} 14(3 \mathrm{~m})$ & TL & $40.8 \pm 4.6 \mathrm{ka} / \mathrm{W} 4957$ & PD & $\mathrm{S}$ & (2) \\
\hline TM (TMA8) (23 m) & ${ }^{14} \mathrm{C}$ & $3,510 \pm 70 \mathrm{yr} \mathrm{BP} / \mathrm{B} 167955$ & HA & $\mathrm{T}$ & (4) \\
\hline F5 (F5-19) (22 m) & ${ }^{14} \mathrm{C}$ & $4,360 \pm 70 \mathrm{yr} \mathrm{BP} / \mathrm{B} 120500$ & HA & $\mathrm{T}$ & (4) \\
\hline $\mathrm{S} 28(18 \mathrm{~m})$ & TL & $<4.1 \pm 0.5 \mathrm{ka} / \mathrm{W} 4958$ & uHD & $\mathrm{B}$ & (2) \\
\hline OR (E)QF3 (17 m) & ${ }^{14} \mathrm{C}$ & $23,560 \pm 360$ yr BP & $\mathrm{PA} / \mathrm{D}$ & $\mathrm{T}$ & (5) \\
\hline OR (Bb)QF2 (25 m) & ${ }^{14} \mathrm{C}$ & $26,650 \pm 260 \mathrm{yr} \mathrm{BP}$ & PD & $\mathrm{S}$ & (5) \\
\hline OR (Ba)QF1 (30 m) & ${ }^{14} \mathrm{C}$ & $29,020 \pm 290$ yr BP & $\mathrm{PA} / \mathrm{D}$ & $\mathrm{B}$ & (5) \\
\hline S34 (PS9b) (127 m) & ${ }^{14} \mathrm{C}$ & $360 \pm 80 \mathrm{yr} \mathrm{BP} / \mathrm{B} 459187$ & $\mathrm{uHD}$ & $\mathrm{T}$ & (2) \\
\hline \multicolumn{6}{|l|}{ Vandenberg } \\
\hline V7 (VAFB2166) & ${ }^{14} \mathrm{C}$ & $930 \pm 120 \mathrm{cal} \mathrm{BP} / \mathrm{B} 63695$ & uHD & $\mathrm{T}$ & (6) \\
\hline $\mathrm{V} 8(3 \mathrm{~m})$ & TL & $4.1 \pm 0.6 \mathrm{ka} / \mathrm{W} 4954$ & wHD & $\mathrm{T}$ & (2) \\
\hline V14 Mod Pond (6 m) & ${ }^{14} \mathrm{C}$ & 2,760 yr BP & HA & $\mathrm{B}$ & (7) \\
\hline V17 (SBA707-90b2) & ${ }^{14} \mathrm{C}$ & $4330 \pm 110 \mathrm{cal} \mathrm{BP} / \mathrm{B} 456056$ & wHD & $\mathrm{T}$ & (2) \\
\hline wV17(SBA707-95b) & ${ }^{14} \mathrm{C}$ & $380 \pm 90$ cal BP $/ B 454738$ & uHD & $\mathrm{T}$ & (2) \\
\hline $\mathrm{V} 24(3 \mathrm{~m})$ & TL & $47.1 \pm 4.8 \mathrm{ka} / \mathrm{W} 4952$ & $\mathrm{PD}$ & $\mathrm{S}$ & (2) \\
\hline V26(VAFB0225) & ${ }^{14} \mathrm{C}$ & $3,040 \pm 100 \mathrm{cal} \mathrm{BP} / \mathrm{B} 63695$ & uHD & $\mathrm{B}$ & (6) \\
\hline V37(SBa931A) & ${ }^{14} \mathrm{C}$ & 7,830 yr BP/ UCR268 & wHD & $\mathrm{S}$ & (8) \\
\hline V37(SBa931A) & ${ }^{14} \mathrm{C}$ & 8,900 yr BP & wHD & $\mathrm{B}$ & (8) \\
\hline V37(VAFB931 $\left.\mathrm{A}_{1}\right)$ & ${ }^{14} \mathrm{C}$ & $8560 \pm 350 \mathrm{cal} \mathrm{BP} / \mathrm{UCR} 268$ & wHD & $\mathrm{B}$ & (6) \\
\hline V37(VAFB931A2) & ${ }^{14} \mathrm{C}$ & $9340 \pm 120 \mathrm{cal} \mathrm{BP} / \mathrm{B} 17001$ & wHD & $\mathrm{B}$ & (6) \\
\hline wV40(VAFB534-1) & ${ }^{14} \mathrm{C}$ & $510 \pm 60 \mathrm{cal} \mathrm{BP} / \mathrm{B} 22818$ & uHD & $\mathrm{T}$ & (6) \\
\hline wV40(VAFB534-2) & ${ }^{14} \mathrm{C}$ & $1,510 \pm 70 \mathrm{cal} \mathrm{BP} / \mathrm{B} 22817$ & $\mathrm{uHD}$ & $\mathrm{S}$ & (6) \\
\hline V42(BearCyn) & ${ }^{14} \mathrm{C}$ & $9,030 \pm 390$ yr BP & wHD & $\mathrm{B}$ & (9) \\
\hline nwV43(VAFB677-1) & ${ }^{14} \mathrm{C}$ & $660 \pm 50$ cal BP/ B112444 & uHD & $\mathrm{T}$ & (6) \\
\hline nwV43(VAFB677-2) & ${ }^{14} \mathrm{C}$ & $930 \pm 80$ cal BP/ B112445 & $\mathrm{uHD}$ & $\mathrm{S}$ & (6) \\
\hline swV43(VAFB67-11) & ${ }^{14} \mathrm{C}$ & $670 \pm 50 \mathrm{cal} \mathrm{BP} / \mathrm{B} 112440$ & $\mathrm{uHD}$ & $\mathrm{T}$ & (6) \\
\hline swV43(VAFB671-2) & ${ }^{14} \mathrm{C}$ & $2,780 \pm 130 \mathrm{cal} \mathrm{BP} / \mathrm{B} 112439$ & $\mathrm{uHD}$ & $\mathrm{B}$ & (6) \\
\hline $\mathrm{V} 45\left(\mathrm{SBa} 670-_{1}\right)$ & ${ }^{14} \mathrm{C}$ & $590 \pm 100 \mathrm{yr} \mathrm{BP} /$ & uHD & $\mathrm{T}$ & (9) \\
\hline V45(VAFB670-1) & ${ }^{14} \mathrm{C}$ & $3,430 \pm 90 \mathrm{cal} \mathrm{BP} / \mathrm{B} 16999$ & wHD & $\mathrm{T}$ & (6) \\
\hline $\mathrm{V} 45(\mathrm{SBa} 670-2)$ & ${ }^{14} \mathrm{C}$ & $3,930 \pm 110$ yr BP & wHD & $\mathrm{T}$ & (9) \\
\hline V45(VAFB670-2) & ${ }^{14} \mathrm{C}$ & $5,290 \pm 80 \mathrm{cal} \mathrm{BP} / / \mathrm{B} 16018$ & wHD & $\mathrm{S}$ & (6) \\
\hline V45(VAFB670-3) & ${ }^{14} \mathrm{C}$ & $7,330 \pm 100 \mathrm{cal} \mathrm{BP} / \mathrm{UCI} 182$ & wHD & $\mathrm{S}$ & (6) \\
\hline V46(VAFB530-1) & ${ }^{14} \mathrm{C}$ & $680 \pm 60 \mathrm{cal} \mathrm{BP} / \mathrm{B} 64145$ & uHD & $\mathrm{T}$ inset & (6) \\
\hline $\mathrm{V} 46\left(\mathrm{SBa}^{2} 30-1\right)$ & ${ }^{14} \mathrm{C}$ & $1,270 \pm 70 \mathrm{yr} \mathrm{BP}$ & uHD & $\mathrm{S}$ inset & (9) \\
\hline V46(VAFB530-2) & ${ }^{14} \mathrm{C}$ & $5,730 \pm 80 \mathrm{cal} \mathrm{BP} / \mathrm{B} 64150$ & wHD & $\mathrm{S}$ & (6) \\
\hline V46(VAFB530-3) & ${ }^{14} \mathrm{C}$ & $7,450 \pm 80 \mathrm{cal} \mathrm{BP} / \mathrm{B} 64151$ & wHD & $\mathrm{S}$ & (6) \\
\hline V46(VAFB530-4) & ${ }^{14} \mathrm{C}$ & $9,000 \pm 90 \mathrm{cal} \mathrm{BP} / \mathrm{B} 31172$ & wHD & $\mathrm{B}$ & (6) \\
\hline V46(VAFB530-5) & ${ }^{4} \mathrm{C}$ & $9,240 \pm 120 \mathrm{cal} \mathrm{BP} / \mathrm{B} 17260$ & wHD & $\mathrm{B}$ & (6) \\
\hline V46(SBa530-2) & ${ }^{14} \mathrm{C}$ & $13,890 \pm 330$ yr BP & $\mathrm{PD}$ & $\mathrm{T}$ & (9) \\
\hline
\end{tabular}

Notes: TL sample sites correspond directly to morphostratigraphic sections (Table 1). Sample depths (m) are in meters subsurface. Previously published archaeology ${ }^{14} \mathrm{C}$ sample sites (site number) correspond to the nearest morphostratigraphic sections $(\mathrm{S}, \mathrm{V})$ in this study. Several ${ }^{14} \mathrm{C}$ sample sites include sea cliff or bluff top locations, positioned due west (w), northwest (nw) or southwest (sw) of the nearest morphostratigraphic sites. ${ }^{14} \mathrm{C}$ samples 
are from charcoal or shells (calibrated for local marine reservoir). See references for laboratory details. Sample ages are in ka for TL samples and in yr BP $( \pm 1 \sigma)$ or cal BP $( \pm 2 \sigma)$ and rounded to the nearest 10 years for ${ }^{14} \mathrm{C}$ samples. Sample stratigraphic positions are given relative to top (T), internal strata (S) and bottom (B) of corresponding deposit types. Deposit types include: unweathered Holocene dune (uHD), weathered Holocene dune (wHD), Pleistocene dune (PA), Holocene alluvium (HA), and Pleistocene alluvium (PA). Tivela stultorum (Pismo beach clams) represent the presence of perennial beaches in the Santa Maria dune sheet area. References include (1) Masters (2006), (2) this article, (3) Jones and Mikkelsen (2006), (4) Knott and Eley (2006), (5) Orme (1992), (6) Vandenberg Air Force Base (VAFB, 2017), (7) Anderson et al., (2015), (8) Glassow and Snethkamp (1981), and (9) Johnson et al., (1991). The three new ${ }^{14} \mathrm{C}$ ages used in this study are from sites S34 (PS9b) and V17 (SBA707-90b2) and wS17 (SBA707-95b2) with a marine reservoir correction of Delta R $=225 \pm 25 \mathrm{yr}$.

Reported ${ }^{14} \mathrm{C}$ deposit ages establish an approximate boundary between 1) the termination of weathered Holocene

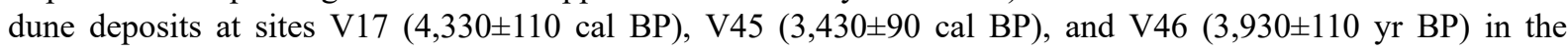
Vandenberg dune sheet and 2) the onset of unweathered Holocene dune deposition in sites V26 $(3,044 \pm 100 \mathrm{cal}$ BP) and swV43 (2,780 $\pm 130 \mathrm{cal} \mathrm{BP})$ in the Vandenberg dune sheet and in site TM $(<3,510 \pm 70 \mathrm{yr}$ BP $)$ in the Santa Maria dune sheet (Table 6). The unweathered dune deposition has continued locally until present time $(0 \mathrm{ka})$ in the Guadalupe dune fields, between sites S8 and S28 in the Santa Maria dune sheet (Figure 8) and at Purisima Point at site V26 in the Vandenberg dune sheet (Figure 11). However, the latest-Holocene dune ramp advance has recently terminated between Mussel Rock and Point Sal at the south end of the Santa Maria dune sheet, with a terminal Holocene dune deposit age of $370 \pm 80 \mathrm{cal} \mathrm{BP}$ at site S34. The latest-Holocene dune sheet advance has also terminated just west of site V17 in the northern part of the Vandenberg dune sheet with a terminal Holocene dune deposit age of $380 \pm 90$ cal BP. A narrow strip of discontinuous unweathered Holocene dunes is located along the crest and seaward slope of the westernmost bluffs south of site V39 in the Vandenberg dune sheet (Figure 11). These erosional remnants of latest-Holocene dune deposits at the south end of the Vandenberg dune sheet are dated to $1,510 \pm 70$-to- $510 \pm 60$ cal BP (site wV40), $930 \pm 80$-to- $660 \pm 50$ cal BP (site nwV43), and $2,780 \pm 130$-to- $670 \pm 50$ cal BP (site swV43). The youngest ages might represent surface midden occupations, thereby post-dating terminal dune advance.

The onset of weathered Holocene dune deposition in the study area is dated to about $\sim 9000 \mathrm{yr}$ BP by ages of $8,560 \pm 350$-to- $9,340 \pm 120$ cal BP (site V37), $9030 \pm 390$ yr BP (site V42), and $8950 \pm 40$-to- $9240 \pm 120$ cal BP (site V46) in the Vandenberg dune sheet (Table 6). The earliest developments of Holocene perennial beaches in the northern Santa Maria dune sheet as established by ${ }^{14} \mathrm{C}$-dated Pismo beach clams (Tivela stultorum) in midden sites near S1 (Figure 8) are dated to $7780 \pm 220$ cal BP -to- $9308 \pm 150$ cal BP (Ca-SLO-801), 8470 \pm 70 cal BP -to$8920 \pm 70$ cal BP (Ca-SLO-832), and $9600 \pm 60$ cal BP (Ca-SLO-1797) as reported in Masters (2006). The earliest-Holocene dune sand supply is expected to have been contemporaneous with early beach development at $\sim 9 \mathrm{ka}$, in the Santa Maria dune sheet. A pair of ${ }^{14} \mathrm{C}$ ages $(6204 \pm 120$ and $6233 \pm 150 \mathrm{cal} \mathrm{BP})$ in a thin weathered Holocene dune deposit at site S10 on the western edge of the Mesa Bluffs predates bluff slope truncation by an abandoned channel of the Arroyo Grande Creek, shown in Figure 8, in mid-Holocene time.

Late-Pleistocene dune ${ }^{14} \mathrm{C}$ ages range in age from $29,020 \pm 290 \mathrm{yr}$ BP in recycled dune sand alluvium in the composite site OR in the Santa Maria dune sheet -to- 13,890 \pm 330 yr BP near the top of a thin and discontinuous pre-Holocene dune layer in site V46 of the Vandenberg dune sheet (Table 6). The timing of the major depositional phases of paleo-dune deposits, including the late-Pleistocene (cemented dune deposits), the middle-Holocene (weathered dune deposits), and the latest-Holocene (unweathered dune deposits) in the study area, are related to corresponding paleo-sea level conditions below.

\section{Discussion}

\subsection{Timeline of Dune Field Advances}

The three paleo-dune deposit types that have been dated in the Santa Maria and Vandenberg dune sheets (Table 6) correspond to three different paleo-sea level conditions in the study area (Figure 15). First, the late-Pleistocene dune deposits developed during a prolonged period (70-13 ka) of low sea levels ( -50 to $-130 \mathrm{~m}$ elevation) along the mid-continental shelf. The late-Pleistocene dune sand was transported across the emerged shelf by eolian processes, as occurred in the nearby San Francisco and Monterey dune sheets (Peterson et al., 2015). Second, the middle-Holocene dune deposits correspond to the slowing of the Holocene marine transgression (9-5 ka), when shoreward wave transport overtook shoreline retreat to supply perennial beaches in the study area (Masters, 2006). And third, the latest-Holocene dune deposits correspond to near high-stand conditions of paleo-sea level $(\sim 3.5-0 \mathrm{ka})$, when net southward longshore transport delivered sand to the southern portions of littoral subcells 
in the study area (Peterson et al., 2009).

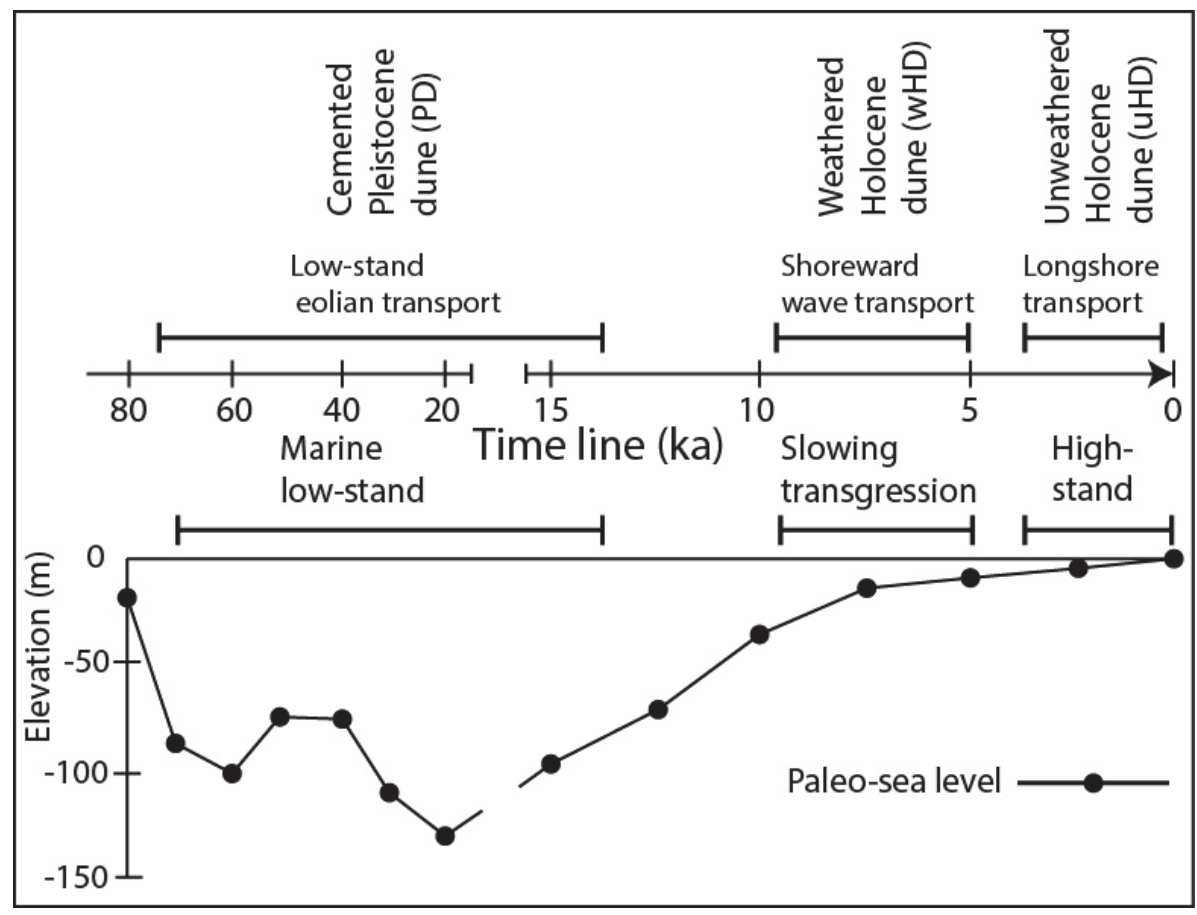

Figure 15. Timelines for coastal sand supply in the study area

Timelines for paleo-sea levels, sand transport mechanisms, and paleo-dune deposition from late-Pleistocene $(80 \mathrm{ka})$ to the present $(0 \mathrm{ka})$. Paleo-sea levels are from Figure 4. Dune deposit ages are grouped from Table 6.

A general hiatus in dune sand supply would have occurred between the termination of cross-shelf eolian transport following shelf submergence, after $18 \mathrm{ka}$ (Figure 15) and the onset of perennial beach development ( $\sim 9$ $\mathrm{ka}$ ) in the study area. The occurrence of such a hiatus is consistent with significant differences in weathering and cementation between overlying Holocene dune deposits and underlying cemented latest-Pleistocene dune deposits in the study area (Figure 7A). The termination of cross-shelf transgression sand supply, after $5 \mathrm{ka}$, and the onset of localized sand supply by longshore transport, by $\sim 3.5 \mathrm{ka}$, are established by the ${ }^{14} \mathrm{C}$ records of dune deposit ages, though visual differences in dune soil weathering are locally striking (Figure 6A).

\subsection{Paleo-Dune Field Migrations as Indicators of Local Paleo-Wind Directions}

Hill-shaded Lidar elevation DEMs (NOAA, 2017) were used to establish orientations of parabolic and transverse paleo-dune forms in the Santa Maria and Vandenberg dune sheets. The paleo-dune migration bearings reflect dominant local wind directions associated with the ages of the paleo-dune deposit types. Representative morphostratigraphic sites (4-6 in number) were selected from surface exposures of each dune deposit type in the northern and southern areas of the Santa Maria dune sheet (Figure 8) and in the northern area of the Vandenberg dune sheet (Figure 11) to measure the corresponding dune form migration bearings relative to true north $\left({ }^{\circ} \mathrm{TN}\right)$. Paleo-wind directions are taken to be $180^{\circ}$ from the preserved dune form migration bearings.

In the northern areas of the Santa Maria dune sheet (Figure 16A), the measured paleo-dune forms yield the following mean and standard deviations $( \pm 1 \sigma)$ of migration bearings from 1) late-Pleistocene dune deposits at sites S11, S13, S14, S17, and S22 (143 $\left.\pm 7^{\circ}\right)$, 2) middle-Holocene dune deposits at sites S2, S6, S20 and S23 $\left(107 \pm 5^{\circ}\right)$, and 3) latest-Holocene dune deposits at sites S18, S26, F5 and TM $\left(110 \pm 3^{\circ}\right)$. The migration bearing means $\pm 2 \sigma$ of the late-Pleistocene and Holocene dune forms do not overlap, indicating a small but significant difference in local paleo-wind directions between late-Pleistocene and Holocene times. There are no significant differences in migration bearings between the middle-Holocene and latest-Holocene dune forms in the northern area of the Santa Maria dune sheet, spanning the Holocene period of local warming and drying (Anderson et al., 2015). Dune migration directions in the southern areas of the Santa Maria dune sheet show substantial variability, likely due to wind flow influences from the high gradient slopes of the Point Sal Ridge (Figure 16B). 

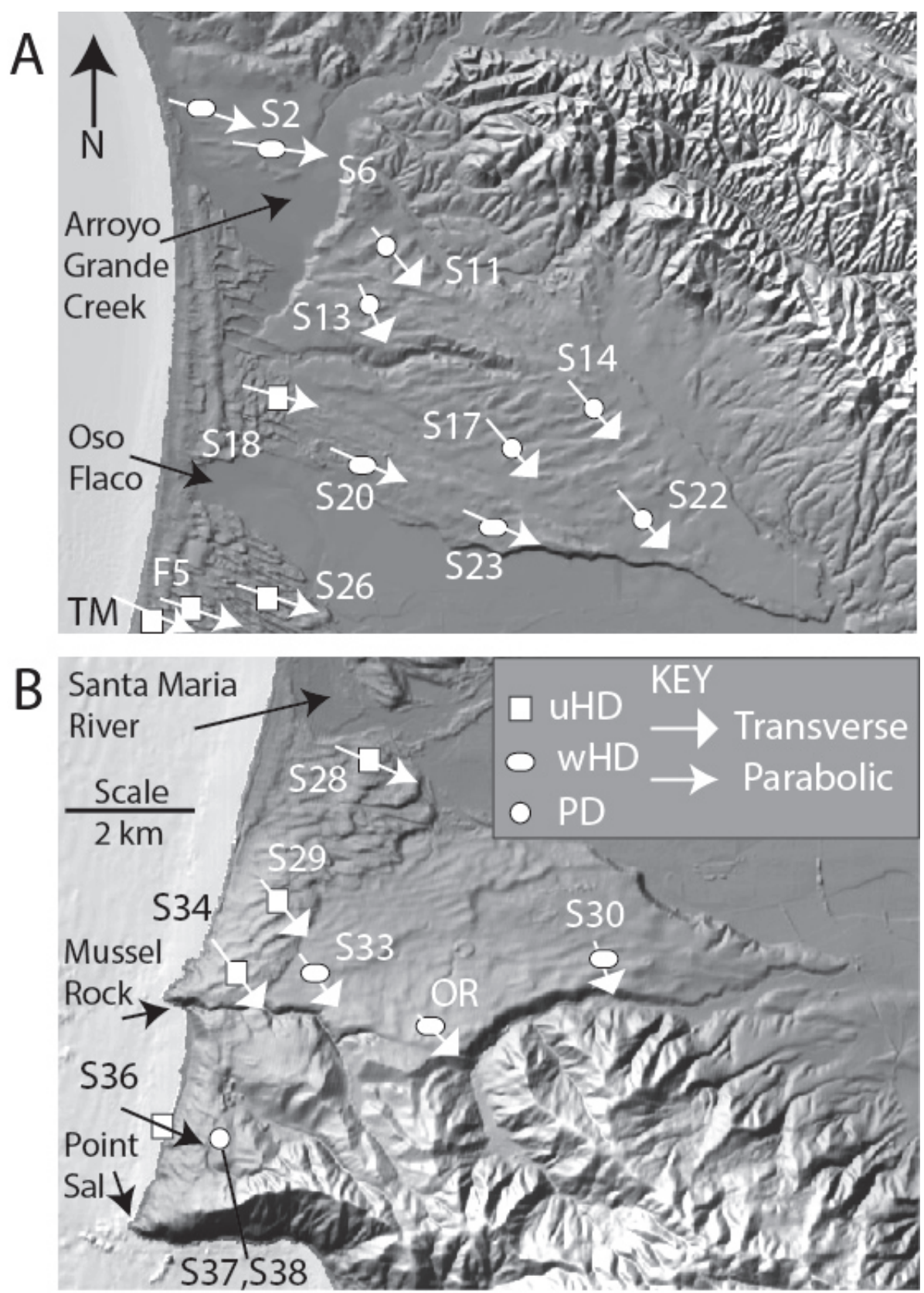

Figure 16. Paleo-dune form orientations in the Santa Maria dune sheet

Part A: Hill-shaded Lidar DEM for the northern area of the Santa Maria dune sheet. Part B: Hill-shaded Lidar DEM for the southern area of the Santa Maria dune sheet. Dune form ages are from corresponding morphostratigraphic sections (S), including unweathered Holocene dune deposits (uHD), weathered Holocene dune deposits (wHD), and cemented Pleistocene dune deposits (PD). Dune form migration directions (arrows) are shown for parabolic and transverse dune forms. See Table 2 for site elevations. Lidar data are from NOAA (2017).

In the northern area of the Vandenberg dune sheet (Figure 17A) the dune form migration bearings of the middle-Holocene dunes at sites V8, V10, V13, V15, V22, and V29 $\left(136 \pm 11^{\circ}\right)$ are not substantially different from the latest-Holocene dunes at sites V7, V9, V11, V21, and V26 $\left(122 \pm 10^{\circ}\right)$. No preserved topographic dune forms were apparent in deflation surfaces of the late-Pleistocene dune deposits at sites V25, V24, V27 and V31 in the Vandenberg dune sheet. Though local pollen records demonstrate progressive warming and drying throughout the Holocene (Anderson et al., 2015), the paleo-climate changes did not include significant changes in dominant local wind directions between middle-Holocene and latest-Holocene time in the study area dune sheets. 
Middle-Holocene sand ramps developed against sea cliffs at the south end of the Vandenberg dune sheet (Figure 17B), where they locally barraged late-Pleistocene gullies that were cut into the uplifted marine terraces ( $\sim 90 \mathrm{~m}$ elevation), such as at site V44. However, latest-Holocene shoreline retreat has undercut and over-steepened the middle-Holocene sand ramps, leading to the narrow ( $\sim 0.5 \mathrm{~km}$ width) strip of truncated eolian sand ramps or 'remnant perched dunes' (Peterson et al., 2017b) along the bluff edge (Figure 11).

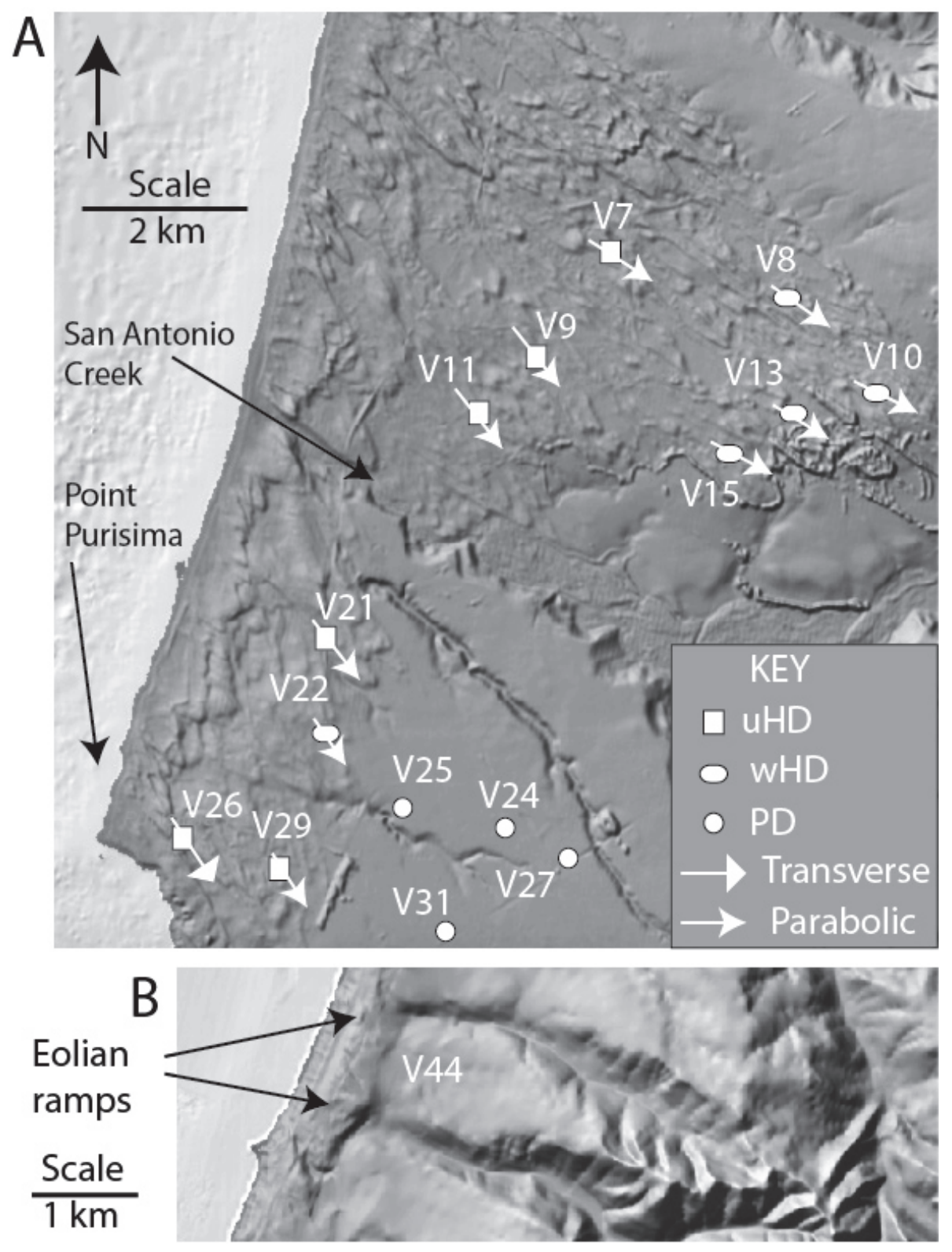

Figure 17. Paleo-dune form orientations in the Vandenberg dune sheet

Part A: Hill-shaded Lidar DEM for the northern area of the Vandenberg dune sheet. Part B: Hill-shaded Lidar DEM for a representative section of middle-Holocene eolian sand ramps that barraged (dammed) gullies cut into uplifted late-Pleistocene marine terraces in the southernmost part of the Vandenberg dune sheet.

Dune form ages are from corresponding morphostratigraphic sections (V), including unweathered Holocene dune deposits (uHD), weathered Holocene dune deposits (wHD), and cemented Pleistocene dune deposits (PD). Dune form migration directions (arrows) are shown for parabolic and transverse dune forms. See Table 2 for site elevations. Lidar data are from NOAA (2017). 


\subsection{Distribution of Dune Deposit Volumes}

Dune sheet landward extents (Figures 8 and 11) and deposit thicknesses (Figures 9, 10, 12, and 13) were likely influenced by topographic relief relative to wind directions in the Santa Maria and Vandenberg dune sheets (Figures 16 and 17). To reduce the bias of topographic influences on paleo-dune deposit distributions, the dune sand accumulations are normalized to volumes. The dune deposit volumes are based on mapped surface areas, as shown in Figures 8 and 11, and measured deposit thicknesses (Tables 4 and 5), as averaged for the north and south parts of each dune sheet (Table 7). The Santa Maria and Vandenberg dune sheets are divided, respectively, at the Oso Flaco Lagoon and Santa Ynez River mid-points. Dune deposit volume calculations are generally rounded to the nearest 10 million cubic meters due to estimated 5-10\% mapping area uncertainties. The loss of paleo-dune deposits to reworking and/or burial in the Santa Maria River Valley (Knott and Eley, 2006), or to reworked dune sand alluvium in gully/slope-wash fills in the steepest bluff slopes (Orme, 1992), are not evaluated in this article.

Table 7. Estimated dune deposit volumes

\begin{tabular}{llll}
\hline Dune Sheet & $\begin{array}{l}\text { Late Pleistocene (PD) } \\
\text { depth/area/volume } \\
\mathrm{m} / \mathrm{km}^{2} / \mathrm{m}^{3}\end{array}$ & $\begin{array}{l}\text { Middle Holocene (wHD) } \\
\text { depth/area/volume } \\
\mathrm{m} / \mathrm{km}^{2} / \mathrm{m}^{3}\end{array}$ & $\begin{array}{l}\text { Latest Holocene (uHD) } \\
\text { depth/area/volume } \\
\mathrm{m} / \mathrm{km}^{2} / \mathrm{m}^{3}\end{array}$ \\
\hline Santa Maria & & & \\
North & $36 / 63 / 1,200 \times 10^{6}$ & $9 / 27 / 240 \times 10^{6}$ & $8 / 18 / 140 \times 10^{6}$ \\
South & $14 / 10 / 140 \times 10^{6}$ & $10 / 13 / 130 \times 10^{6}$ & $13 / 36 / 470 \times 10^{6}$ \\
Total & vol. $1,340 \times 10^{6}$ & vol. $370 \times 10^{6}$ & \\
& & & \\
Vandenberg & & $7 / 37 / 260 \times 10^{6}$ & \\
North & $3 / 4 / 10 \times 10^{6}$ & $18 / 3 / 50 \times 10^{6}$ & $5 / 22 / 110 \times 10^{6}$ \\
South & $1 / 0.5 / 0.5 \times 10^{6}$ & vol. $310 \times 10^{6}$ & $0.5 / 1 / 0.5 \times 10^{6}$ \\
Total & vol. $10 \times 10^{6}$ & vol. $110 \times 10^{6}$ \\
\hline
\end{tabular}

Notes: Dune deposit volumes (m3) are computed from measured surface areas (km2) (Figs. 6 and 9) and corresponding averaged thickness (m) of deposit type sections (bold type in Tables 4 and 5). The north and south areas of the Santa Maria and Vandenberg dune sheets, respectively, are divided at the Oso Flaco and Santa Ynez River mid-points (Figures 6 and 9). Due to the steep sand ramp geometry in the southernmost parts of the Santa Maria dune sheet (sites 36 and 39) and the Vandenberg dune sheet (sites V42, V43, V45, and V46) the thicknesses of the dune deposits for those sections are taken to be one half of their reported values from Tables 4 and 5 .

The estimated late-Pleistocene dune deposit volumes in the Santa Maria dune sheet are highly asymmetric ranging from 1,200 million cubic meters $\left(1,200 \times 10^{6} \mathrm{~m}^{3}\right)$ in the north -to- $140 \times 10^{6} \mathrm{~m}^{3}$ in the south (Table 7). The asymmetry reverses in latest-Holocene time as the latest-Holocene dune deposit volumes vary from $140 \times 10^{6} \mathrm{~m}^{3}$ in the north -to- $470 \times 10^{6} \mathrm{~m}^{3}$ in the south. Late-Pleistocene dune deposits reach only $\sim 10$ million cubic meters in the northern part of the Vandenberg dune sheet, and they are negligible to the south of the Santa Ynez River. The middle-Holocene and latest-Holocene dune deposit volumes, respectively, in the northern part of the Vandenberg dune sheet are estimated to be $260 \times 10^{6} \mathrm{~m}^{3}$ and $110 \times 10^{6} \mathrm{~m}^{3}$. By comparison, the middle-Holocene and latest-Holocene dune deposits in the southern part of the dune sheet, respectively, reach only $50 \times 10^{6} \mathrm{~m}^{3}$ and $\sim 0.5 \times 10^{6} \mathrm{~m}^{3}$. The paleo-wave climates and paleo-shoreline orientations that led to the very-asymmetric paleo-dune volume distributions in the Santa Maria and Vandenberg dune sheets are discussed in detail below.

\subsection{North Pacific Ocean Wind/Wave Stress}

Paleo-wave climates in the south-central California coastal region (Figure 2) have been estimated from modeled paleo-sea level pressure gradients, as down-sampled from the GENMOM model (Alder and Hostetler, 2015), at $3 \mathrm{ka}$ time slices from 21 to $0 \mathrm{ka}$ (Figure 18). The paleo-wave climate forcing is calibrated to modern deep water wave directions from an offshore buoy, Santa Barbara Buoy LLNR 198 (Figure 1; NOAA, 2016), as previously reported by Peterson et al. (2017b). The dominant wave forcing in the study area occurs during winter months, Dec-Jan-Feb (DJF), when averaged significant wave heights $\left(\mathrm{H}_{1 / 3}\right)$ are $1.5-3.5 \mathrm{~m}$, and extreme storm waves reach 7-8 m height. Averaged monthly winter wave directions for the years 2014-2015 yielded a mean of $\sim 290^{\circ}$ TN. The winter storm waves propagate to the southeast from the North Pacific Low Pressure Area (NPLPA). The 
NPLPA migrated to its present position from a more southerly position during the last glacial maximum (LGM) at $21-18 \mathrm{ka}$. This northward migration of the NPLPA would have resulted in a $25-30^{\circ}$ clockwise rotation of winter storm wave propagation directions from the LGM $(21 \mathrm{ka})$ to the present $(0 \mathrm{ka})$. The nearly north-south oriented paleo-shorelines of the Santa Maria and Vandenberg dune sheets should have been very susceptible to these changes in the paleo-wave propagation directions, as discussed below.

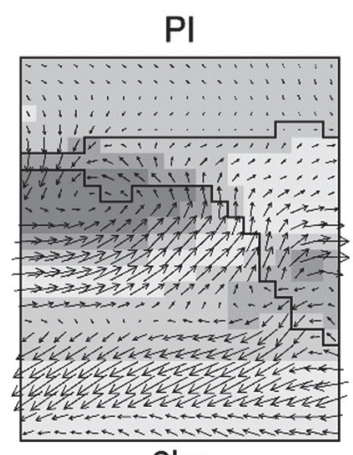

$6 \mathrm{ka}$

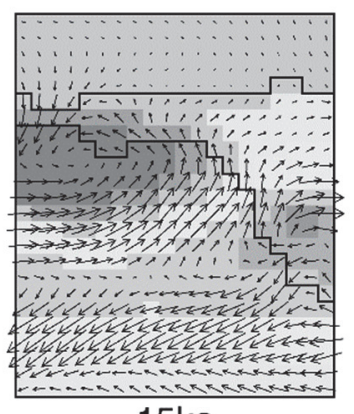

$15 \mathrm{ka}$

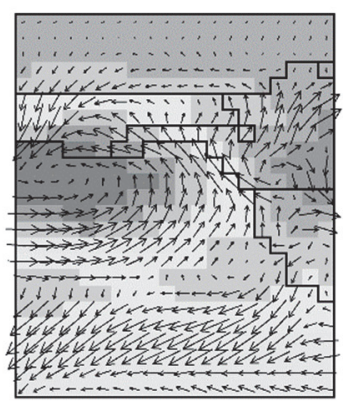

$9 \mathrm{ka}$

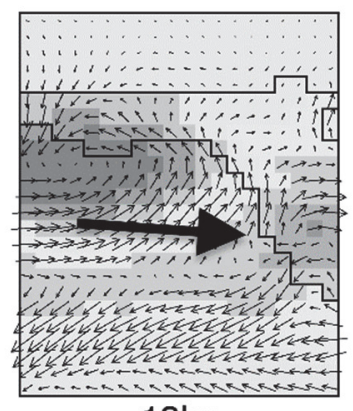

$18 \mathrm{ka}$

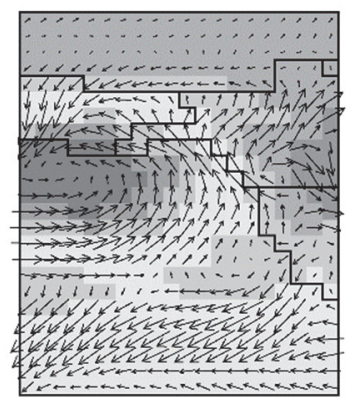

$3 \mathrm{ka}$

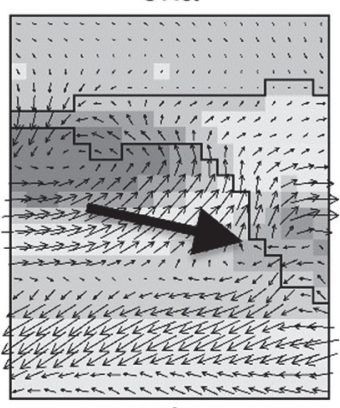

$12 \mathrm{ka}$

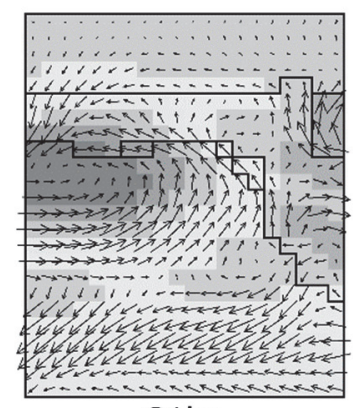

$21 \mathrm{ka}$

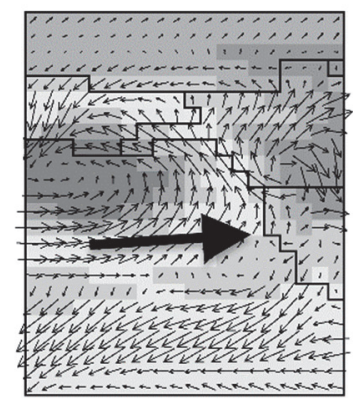

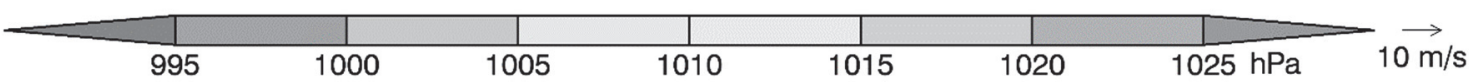

Figure 18. Paleo-wind and associated wave stress from the Northeast Pacific Ocean

Surface air pressure gradients $(\mathrm{hPa})$ and wind stress vectors $\left(\mathrm{ms}^{-1}\right)$ are shown for winter months (DJF) at $3 \mathrm{ka}$ time slices for the last $21 \mathrm{ka}$ (Alder and Hostetler, 2015). The modeled winter winds are used to estimate winter storm wave forcing in the North Pacific Low Pressure Area (NPLPA). For reference purposes, the storm wave propagation directions (bold arrows) are drawn from the central position of the $1000 \mathrm{hPa}$ contour to the study area shoreline. The stepped black line approximates the North America West Coast. Figure is redrafted from Peterson et al. (2017b).

\subsection{Shelf Bathymetry, Paleo-Shoreline Orientations, and Dune Sand Supply}

Several data sets are combined to construct a framework model of offshore sand supply to the paleo-dune deposits in the Santa Maria and Vandenberg study area. The origins of the large late-Pleistocene dune deposits in the San Maria dune sheet (Figure 8) are of particular interest. The volume of late-Pleistocene dune deposits in the Santa Maria dune sheet, $1,340 \times 10^{6} \mathrm{~m}^{3}$ (Table 7), are conservative due to presumed erosion and/or burial of 
pre-Holocene dune deposits in the Santa Maria River Valley. A late-Pleistocene paleo-wind direction of $\sim 320^{\circ}$ TN is reversed from late-Pleistocene dune form migration bearings of $\sim 140^{\circ}$ in the northern area of the Santa Maria dune sheet (Figure 16A). A projection of the $320^{\circ}$ wind direction intersects the low-stand paleo-shoreline, at $-100 \pm 25 \mathrm{~m}$ elevation (Figure 4A), which is $20-30 \mathrm{~km}$ distance to the northwest of the Santa Maria River Valley. Paleo-wave climate forcing (Figure 18) of slight net northward littoral transport along the $-100 \mathrm{~m}$ elevation contour, confirms the potential for the development of a low-stand depocenter, at a paleo-shoreline inflection area, located northwest of the Santa Maria River Valley (Figure 19). River sand discharged to the low-stand paleo-shorelines by the Santa Maria River throughout low-stand time, 70-13 ka (Figure 15), could have supplied the large low-stand depocenter during late-Pleistocene time.

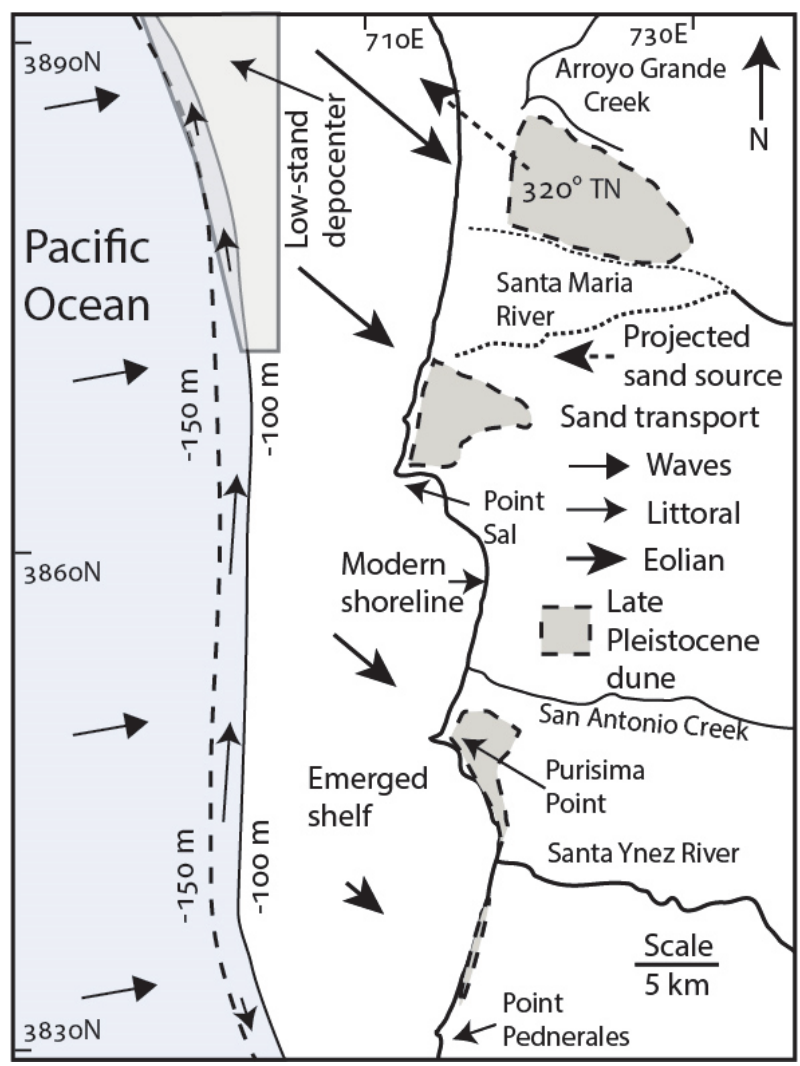

Figure 19. Low stand sand supply to the Santa Maria and Vandenberg dune sheets

Deep water winter-wave propagation directions (arrows) during latest-Pleistocene time (21 ka) are from Figure 18. Paleo-shoreline elevations of $\sim 100 \pm 25 \mathrm{~m}$ during late Pleistocene low-stand conditions are from Figure 4A. An interpreted low-stand (mid-shelf) depocenter (shaded) is projected from paleo-wind directions (Figure 16A) and paleo-wave climate/paleo-shoreline geometries. Late-Pleistocene dune deposits mapped onshore (shaded) are from Figures 8 and 11 .

Unlike the large late-Pleistocene dune deposit volumes in the Santa Maria dune sheet, no obvious mid-shelf features were found to correspond to the very-small late-Pleistocene dune volumes $\left(10 \times 10^{6} \mathrm{~m}^{3}\right)$ in the north part of the Vandenberg dune sheet (Table 7; Figure 19). A slight net northward transport of discharged river sand from the Santa Ynez River, intersecting the low-stand paleo-shorelines some $20 \mathrm{~km}$ offshore of the present Santa Ynez River mouth, could have supplied a southeast directed cross-shelf eolian supply to the small paleo-dune deposits. However, no late-Pleistocene migratory dune deposits were observed north of San Antonio Creek (Figure 11), leaving the origins of the very-small late-Pleistocene dune deposits at Purisima Point unresolved.

Middle-Holocene paleo-dune deposits are widespread in the Santa Maria and Vandenberg dune sheets, respectively, accounting for $370 \times 10^{6} \mathrm{~m}^{3}$ and $310 \times 10^{6} \mathrm{~m}^{3}$ in total volumes (Table 7). The middle-Holocene dune volumes in the Santa Maria dune sheet are assumed to be conservative due to their apparent erosion from alluvial truncation along both the north and south sides of the Santa Maria River Valley (Figure 16). A lack of Holocene deposits along the sides of the Santa Ynez River Valley (Figure 11) precludes any significant loss of onshore dune deposits to the Santa Ynez River Valley processes. The sources of middle-Holocene dune deposits to both 
the Santa Maria and Vandenberg dune sheets were derived from the remobilization of pre-existing sand deposits from the mid- and inner-continental shelf (Figure 20) during the Holocene marine transgression. Nearly orthogonal deep water wave directions at $\sim 9-6$ ka (Figure 18) likely led to the relatively even distribution of middle Holocene dune deposits between the north and south parts of the Santa Maria dune sheet. As will be discussed below, it is not known whether such an even north-south distribution also once occurred in the Vandenberg dune sheet.

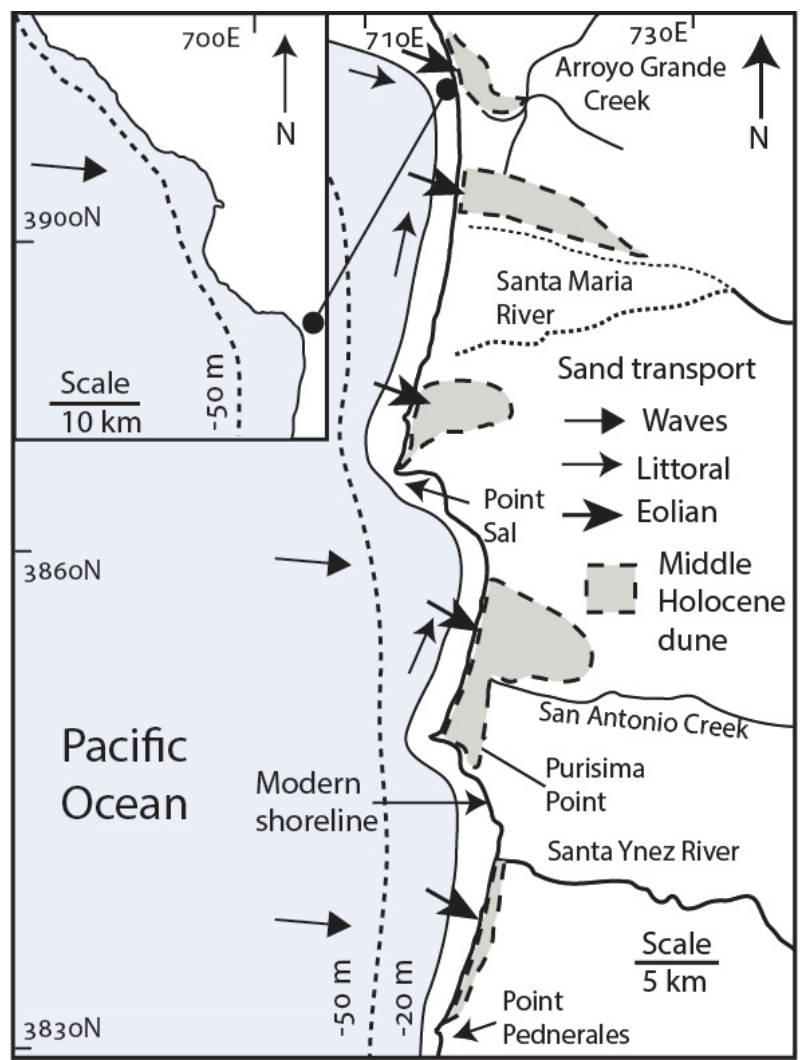

Figure 20. Marine transgression sand supply to the Santa Maria and Vandenberg dune sheets

Deep water winter-wave propagation directions (arrows) during middle-Holocene time (9-6 ka) are from Figure 18. The paleo-shoreline shown at the $-20 \mathrm{~m}$ elevation contour is taken from the paleo-sea level curve at $8 \mathrm{ka}$ (Figure 4B). Middle-Holocene dune deposits, mapped onshore (shaded), are from Figures 8 and 11. Middle Holocene dune migration directions (arrows) are from Figures 16 and 17.

The substantial asymmetry between middle-Holocene dune deposit volumes in the north part $\left(260 \times 10^{6} \mathrm{~m}^{3}\right)$ and south part $\left(50 \times 10^{6} \mathrm{~m}^{3}\right)$ of the Vandenberg dune sheet (Table 7) could be influenced by the higher elevations of uplifted marine terraces (MIS7 terraces in Figure 4A), differing by as much as $50 \mathrm{~m}$ of relative uplift to the south of the Santa Ynez River. However, mean surface elevations of the most-proximal middle-Holocene dune deposits

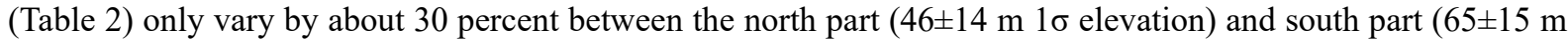
$1 \sigma$ elevation) of the Vandenberg dune sheet. These differences are seemingly too small to account for the $5 \mathrm{x}$ difference in dune deposit volumes. As will be discussed below, the small volume of middle-Holocene dunes in the south part of the Vandenberg dune sheet could be attributed to extensive sand ramp erosion in very latest-Holocene time.

Latest-Holocene dune deposit volumes are unevenly distributed between the Santa Maria dune sheet $\left(610 \times 10^{6}\right.$ $\mathrm{m}^{3}$ ) and Vandenberg dune sheets $\left(110 \times 10^{6} \mathrm{~m}^{3}\right)$ (Table 7), thereby arguing for origins that differ from those of the middle-Holocene dune deposits. As previously mentioned in Section 5.3 above, there are opposite asymmetries in latest-Holocene dune deposit distributions in the north part $\left(140 \times 10^{6} \mathrm{~m}^{3}\right)$ and south part $\left(470 \times 10^{6} \mathrm{~m}^{3}\right)$ of the Santa Maria dune sheet relative the north part $\left(110 \times 10^{6} \mathrm{~m}^{3}\right)$ and south part $\left(0.5 \times 10^{6} \mathrm{~m}^{3}\right)$ of the Vandenberg dune sheet. Such asymmetries between the two dune sheets and within the two dune sheets can be explained by conditions of net southward longshore transport and relative efficiencies of sand trapping within the different subcells during the latest-Holocene conditions of marine high-stand (Figure 21). The Santa Maria dune sheet 
benefitted from longshore transport of innermost-shelf deposits from distances of as much as $100 \mathrm{~km}$ to the north of the dune sheet (Figure 2). The availability of such sand supplies from the inner-shelf is indicated by the presence of late-Holocene dunes ( $\leq 6 \mathrm{ka}$ ) at Morro Bay (Orme and Tchakerian, 1986). By comparison, the Vandenberg dune sheet only received limited sand supply from southward longshore sand transport around Point Sal. The relative trapping efficiencies of the different subcells during latest-Holocene time are discussed below.

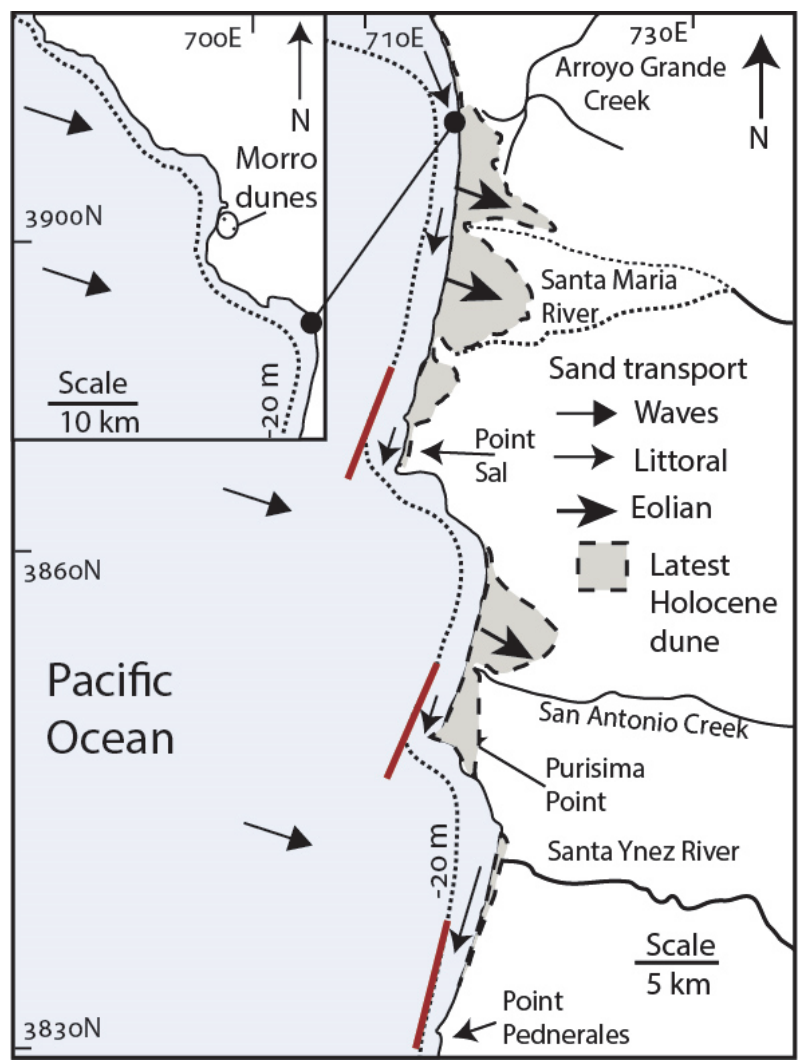

Figure 21. High-stand sand supply to the Santa Maria and Vandenberg dune sheets

Deep water winter-wave propagation directions during latest-Holocene time (3-0 ka) are from Figures 2 and 18. Orientations of innermost-shelf contours (-20 m elevation) are shown (bold lines) at the south ends of subcells at Point Sal, Purisima Point and Point Pednerales. Latest-Holocene dune deposits mapped onshore (shaded) are from Figures 8 and 11. Latest-Holocene dune migration directions (arrows) are from Figures 16 and 17.

Latest-Holocene deep-water winter waves approached the study area shorelines from the northwest (Figures 2 and 18), but shoreline orientations at the Point Sal, Purisima Point and Point Pednerales were nearly orthogonal to the incident wave approach (Figure 21). These nearly orthogonal shoreline orientations reduced net southward longshore sand transport in the southern parts of the corresponding subcells. Such reductions in longshore transport efficiency should 1) locally increase sand residence time in the nearshore and associated beaches and 2) permit onshore winds to transport surplus beach sand to adjacent dune fields (Peterson et al., 2009). Although all three subcells, including Point San Luis-Point Sal, Point Sal-Purisima Point, and Purisima Point-Point Pednerales, show similar orientations of their southernmost shorelines, only the Point Pednerales headland area lacks an equivalent nearly-orthogonal orientation of the innermost-shelf bathymetric contour at $-20 \mathrm{~m}$ elevation. The higher relative-angle of incident wave attack in the nearshore area at the south end of the Vandenberg dune sheet permitted effective longshore sand transport around the Point Pednerales promontory. The loss of nearshore sand from the south end of the Point Pednerales subcell probably 1) limited a contiguous development of latest-Holocene dune deposits south of site V39 and 2) lead to widespread erosion of both the latest-Holoceneand middle-Holocene sand ramps in the southernmost end of the Vandenberg dune sheet (Figures 11 and 17B).

\subsection{Declining Rates of Longshore Sand Supply and Implications for Future Beach Erosion}

Declining rates of recent longshore sand supply in the Santa Maria and Vandenberg dune sheet beaches are evident from deflation and/or slope failures of eolian sand ramps at the south ends of the dune sheets (Figures 
16B and 17B). Coastline orientations at the fault block headlands of Point Sal and Point Arguello (Figure 2) are sufficiently offset to serve as check-valves, permitting episodic southward sand transport around the promontories but no returning northward sand transport. Declining rates of longshore sand replenishment in the Point Sal subcell have led to 1) deflation of latest-Holocene dune deposits in the transverse dune sand ramp at site S29 (Table 4), thereby exposing underlying middle-Holocene dune deposits north of Mussel Rock and 2) implied beach retreat between Mussel Rock and Point Sal. Beach retreat at the southernmost end of the Santa Maria subcell is implied by the undercutting of the latest-Holocene sand ramp at site S36 (Figure 22A). The progressive slope failures at site $\mathrm{S} 36$ have increased slope gradients from $15^{\circ}$ in the un-eroded ramp deposits above $90 \mathrm{~m}$ elevation -to- $35^{\circ}$ (angle of repose) in eroded slopes below the $90 \mathrm{~m}$ elevation rim. A seaward projection of the original ramp slope angle $\left(15^{\circ}\right)$ yields a beach retreat of $\sim 200 \mathrm{~m}$ at the south end of the Santa Maria dune sheet. The dated termination of latest-Holocene dune ramp advance south of Mussel Rock at site S34 ( $370 \pm 80$ cal BP) (Table 6) suggests that the ongoing shoreline retreat between Mussel Rock and Point Sal, at the south end of the Santa Maria dune sheet, is very recent $(<500 \mathrm{yr}$ BP).

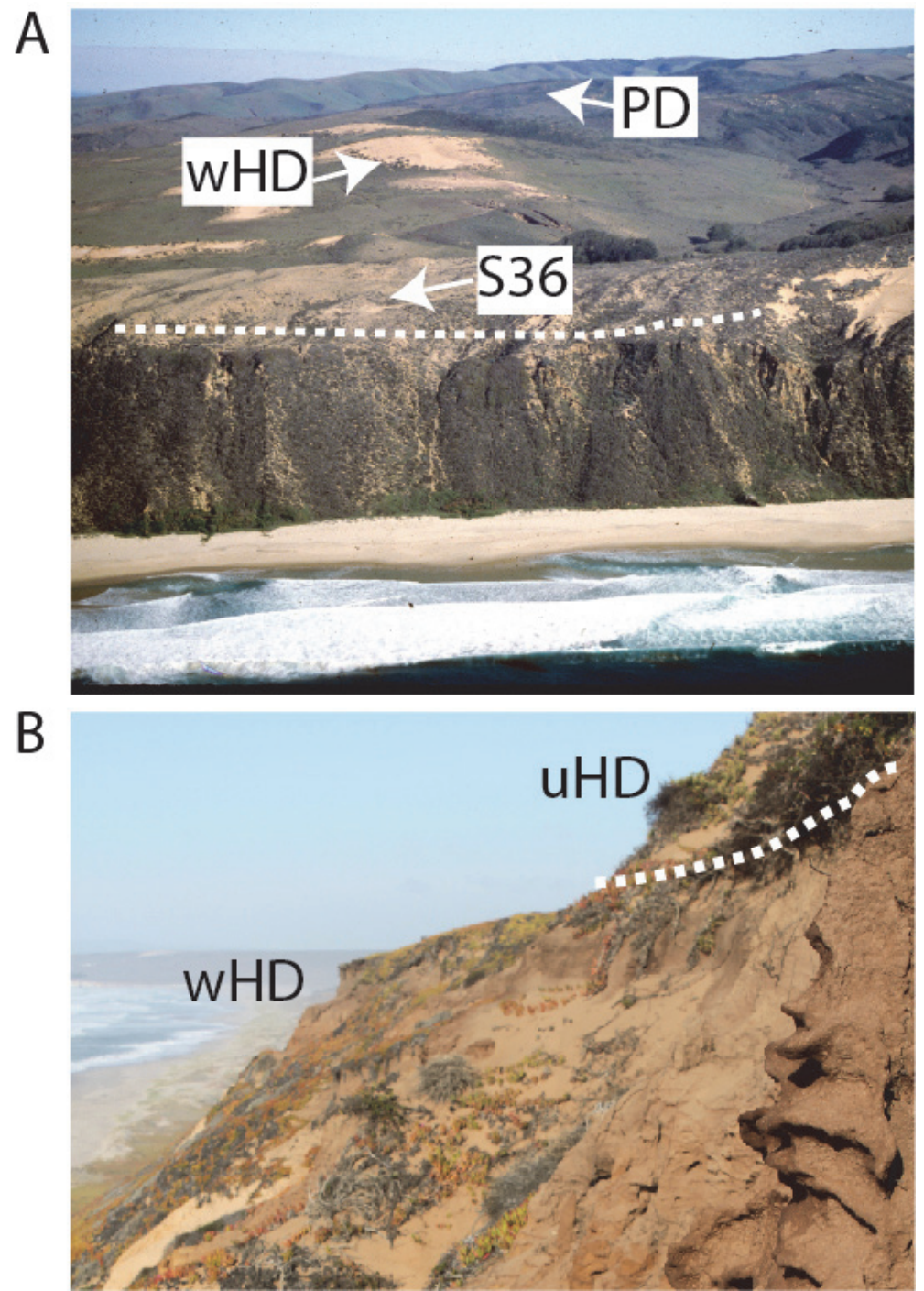

Figure 22. Retreating Holocene sand ramps in the Santa Maria and Vandenberg dune sheets

Part A. Photo (view east) of an eroded eolian sand ramp at site S36, (95 m elevation), between Mussel Rock and Point Sal, at the south end of the Santa Maria dune sheet (Figures 8 and 9). Landward extents of weathered middle-Holocene dune (wHD) deposits and late-Pleistocene dune (PD) deposits are shown in the photo-background. Photo (1989): Copyright (C) 2002-2017 Kenneth \& Gabrielle Adelman, California Coastal Records Project www.Californiacoastline.org. Part B: Photo (view north) of an eroded eolian sand ramp at site V39 (45 m elevation) near the south end of the Vandenberg dune sheet (Figures 11 and 13). Eroded unweathered latest-Holocene dune (uHD) deposits overlie a sharp contact (white dashed line) with weathered middle-Holocene dune (wHD) deposits. 
Sand ramp erosion at the south end of the Vandenberg dune sheet is far more advanced than in the Santa Maria dune sheet. No contiguous latest-Holocene sand ramp deposits exist south of site V39 in the Point Pednerales subcell (Figures 11 and 13), and widespread erosion of the middle-Holocene sand ramp deposits occurs between sites V39 and V46 (Figure 22B). Sea cliff retreat is locally reduced or stabilized between site S46 and Point Pednerales (Figure 11) due to tectonic uplift of bedrock above the high tide level at the southernmost end of the Vandenberg dune sheet (Figure 13). Mean ${ }^{14} \mathrm{C}$ ages of terminal latest-Holocene eolian sand ramp remnants at site wV40 ( 1.0 ka) and site swV43 ( 1.7 ka) (Table 7) suggest that sand ramp erosion at the south end of the Vandenberg dune sheet was likely underway by $1.0-1.5 \mathrm{ka}$. It is assumed that a potential future sea level rise of 1-2 $\mathrm{m}$ following predicted global warming in the next century (DeConto and Pollard, 2016; Mengel et al., 2016) will accelerate the ongoing beach retreat and further erode the remaining eolian sand ramp deposits at the south ends of the Santa Maria and Vandenberg dune sheets.

Most importantly to regional coastal sand supply, the dune sheet records of localized sand supply, termination of cross-shelf sand supply, and diminishing longshore sand catchment, serve as proxies for much broader shoreline responses to future accelerated rates of sea level rise. The along-coast extents of 'active migratory dunes' in the study area ( $\sim 250 \mathrm{~km}$ in length) from Point Sur to Point Conception (Figure 1), total only about $25 \mathrm{~km}$ in length. They are localized in the Guadalupe dune field just north of Point Sal Ridge (Figure 8), the Purisima dune field located just north of Purisima Point (Figure 11), and the Morro Bay sand spit (Figure 2). The other 90 percent of the study area coastline is contributing sand to the southward net longshore transport, with little to no river sand supply and no new cross-shelf sand supply. The narrow beaches ( $\leq 50 \mathrm{~m}$ width) that comprise $>75$ percent of the study area coastline (Table 3 ) will not survive a near future 1-2 $\mathrm{m}$ rise in sea level, based on a conservative $\geq 50: 1$ ratio of retreat distance to sea level rise.

\subsection{Regional Comparisons of Large Paleo-Dune Sheets in the Central West Coast of North America}

The Santa Maria and Vandenberg dune sheets are like the other major paleo-dune sheets in the Central West Coast of North America in that they largely originated from late-Pleistocene marine low-stand sand depocenters (Figure 1). The higher-latitude shelf depocenter in Oregon (OR) received sand from rivers located up to several hundred kilometers south of the associated onshore paleo-dune sheets (Scheidegger et al., 1971; Peterson et al., 2007). The lower-latitude shelf depocenters in Baja California Sur (BCS) were apparently supplied by shelf sand sources located up to several hundred kilometers north of their respective onshore paleo-dune sheets (Peterson et al., 2017a). But the mid-latitude Santa Maria and Vandenberg low-stand shelf depocenters developed in close-proximity to the Santa Maria and Santa Ynez River valleys (Figure 2), as did the nearby San Francisco and Monterey shelf depocenters, relative to their respective river sand sources, i.e. the Sacramento-San Joaquin and Salinas Rivers (Schlocker, 1974; Best and Griggs, 1991; Peterson et al., 2015). The mid-latitude shelf depocenters, located offshore of San Francisco and Santa Maria, were situated nearly due east of the North Pacific Low Pressure Area (NPLPA) position in late-Pleistocene time. These mid-latitude positions resulted in a slight northward littoral transport (Figure 18) and long-term sand storage in broad emerged-shelf sand traps. The accumulated depocenter sand was transported directly across the shelf by 1) eolian transport during marine low-stand conditions and 2) shoreward wave transport during the Holocene marine transgression.

The Santa Maria and Vandenberg paleo-dune sheet shorelines experienced a slight southward littoral transport during latest-Holocene time due to a northward shift of the NPLPA in late-Holocene time (Figure 18). A similar reversal of net littoral transport directions between late-Pleistocene and latest-Holocene time were interpreted to have occurred in the two other mid-latitude dune sheets at San Francisco and Monterey Bay (Figure 2) (Peterson et al., 2015). However, substantial changes in modern coastline orientations in the Santa Maria-Vandenberg study areas (Figure 21) clearly identified the locally variable sand trapping efficiencies of the corresponding littoral subcell shorelines (Peterson et al., 2009) under the reversed net-southward littoral transport conditions in latest-Holocene time. Due to both their mid-latitude locations and variable coastline orientations, the paired Santa Maria and Vandenberg dune sheets uniquely resolved all three of the coastal sand supply conditions during late-Pleistocene, middle-Holocene, and latest-Holocene time, in the study region.

\section{Conclusions}

The Santa Maria and Vandenberg dune sheets are uniquely situated to test relations between paleo-sea levels, paleo-wave climate, paleo-shoreline orientations, and long-term coastal sand supply. The timings of marine sand supply to the two dune sheets correspond to 1) marine low-stand conditions during late- Pleistocene time, 2) shoreward wave transport following slowing of the Holocene marine transgression, and 3) alongshore variations in net-southward littoral sand transport during the latest-Holocene marine high-stand. Paleo-climate conditions were favorable to eolian sand transport throughout latest-Pleistocene and Holocene time. However, local 
topography influenced dune migration directions and possibly the landward extent and thickness of some dune deposits. To compensate for topographic relief influences, dune sand supply was normalized to sand volume measurements. Strong asymmetries in sand volumes from the different ages of dune sand supply to the Santa Maria and Vandenberg dune sheets demonstrate the key importance of paleo-shoreline orientations relative to estimated paleo-wave propagation directions from the North Pacific Low Pressure Area. In latest-Holocene time, alongshore variations in littoral sand trapping efficiencies gave rise to localized dune sand accretion or permanent sand loss around fault/lithology offset promontories. Ongoing sand loss and associated shoreline retreat at the south ends of the Santa Maria and Vandenberg dune sheets could be accelerated by future sea level rise following predicted global warming during the next century. Regionally, the dune sheet records of terminated across-shelf sand supply and ongoing net longshore transport serve as proxies for narrow beach susceptibility to future sea level rise.

\section{Acknowledgements}

Bob Gray provided the early encouragement, sea cliff measured sections, and geomorphic insights to the Vandenberg dune sheet deposits that helped to launch this study. We are indebted to his generosity. Tim Peterson assisted with preliminary field reconnaissance. Jeremy Stanton provided background on seasonal directional wave forcing in the study area. Adelaide Perr assisted with field site mapping, sand auger drilling, TL sampling, and field logistics. Kathleen Gerber provided the geotechnical borehole data from the Vandenberg Air Force Base. Roscoe Loetzerich assisted with transport logistics in the Vandenberg Air Force Base. Paul Vincent provided GIS support for Lidar and bathymetry analyses and radiocarbon sample site identification in the Vandenberg Air Force Base. The Cities of Pismo Beach and Grover Beach provided borehole data on dune thickness in the Santa Maria dune sheet. Support for field logistics, thermoluminescence dating, and ${ }^{14} \mathrm{C}$ dating in the Vandenberg and Santa Maria dune sheets was provided by the U.S. Air Force. Additional support for dune deposit TL dating was provided by Wollongong University, Wollongong, New South Wales, Australia.

\section{References}

Aitken, M. J. (1985). Thermoluminescence dating. Studies in Archaeological Science. Academic Press, London.

Alder, J. R., \& Hostetler, S. W. (2015). Global climate simulations at 3000-year intervals for the last 21,000 years with the GENMOM coupled atmosphere-ocean model. Climate of the Past, 11, 449-471. https://doi.org/10.5194/cp-11-449-2015

Anderson, R. S., Ejarque, A., Rice, J., Smith, S. J., \& Lebow, C. G. (2015). Historic and Holocene environmental change in the San Antonio Creek Basin, mid-coastal California. Quaternary Research, 83, 273-286. https://doi.org/10.1016/j.yqres.2014.11.005

ASTM. (2017). ASTM Standard Guide D5434-12. Accessed March 3, 2017. Retrieved from https://www.astm.org/

Bard, B., Hamelin, R. G., \& Fairbanks, R. (1990). U-Th obtained by mass spectrometry in corals from Barbados: sea level during the past 130,000 years. Nature, 346, 456-458. https://doi.org/10.1038/346456a0

Best, T. C., \& Griggs, G. B. (1991). A sediment budget for the Santa Cruz littoral cell, California. In R.H. Osbourne (Ed), From Shoreline to Abyss: Contributions in Marine Geology in Honor of Francis Parker Shepard: Society for Sedimentary Geology Special Publication, 46, 35-50.

Birkeland, P. W. (1999). Soils and Geomorphology. Oxford University Press, New York.

Bressolier, C., Froidefond, J. M., \& Thomas, Y. F. (1990). Chronology of coastal dunes in the south-west of France. Dunes of the European coasts. Geomorphology-hydrology-soils. Catena Supplement, 18, 101-107.

Cooper, W. S. (1958). Coastal sand dunes of Oregon and Washington. Geological Society of America Memoir, 72, $169 \mathrm{p}$.

Cooper, W. S. (1967). Coastal dunes of California. Geological Society of America Memoir, 104, 131.

DeConto, R. M., \& Pollard, D. (2016). Contribution of Antarctica to past and future sea-level rise. Nature, 531, 591-597. https://doi.org/10.1038/nature17145

Dibblee, T. W. (1950). Geology of Southwestern Santa Barbara County, California: Point Arguelo, Lompoc, Point Conception, Los Olivos, and Gaviota Quadrangles. California Department of Natural Resources, Division of Mines, Bulletin No. 150, San Francisco

Earth Systems Pacific. (2005). Proposal for a Soils Engineering Report, Pismo Pier Plaza. Doc 0509-016. PRP. San Luis Obispo. California, $24 \mathrm{p}$. 
Glassow, M. A., \& Snethkamp, P. E. (1981). Archaeological data recovery program in relation to Space Shuttle development, Vandenberg Air Force Base, California. University of California Santa Barbara. Unpublished Technical Report.

Google Earth. (2016). Google Earth. Satellite images and interactive maps 2013-2016. https://earth.google.com/. Accessed December 10, 2016.

Gray, R. S. (2004). The paleontologic investigations and reconnaissance survey of sea-cliffs, coastline and assorted drainages, streams, and canyons, Vandenberg Air Force Base. Final Technical Report to Earthworks and Vandenberg Air Force Base. Vandenberg, California, 57p.

Heusser, L. E. (1995). Pollen stratigraphy and paleoecologic interpretation of the 160-ky record from Santa Barbara Basin, Hole 893A1. Proceedings of the Ocean Drilling Program, 146(2), 265-279.

Inman, D. L., \& Jenkins, S. A. (1999). Climate change and the episodicity of sediment flux of small California rivers: Journal of Geology, 107, 251-270. https://doi.org/10.1086/314346

Johnson, D. L. (1972). Landscape evolution on San Miguel Island, California. (Ph.D. Thesis), University of Kansas, Lawrence.

Johnson, D. L., Glassow, M. A., \& Graettinger, K. B. (1991). A field guide to the geoarchaeology of the Vandenberg-Lompoc-Point Conception Area, Santa Barbara County, California. In M.J. Walawender \& B.B. Hanon (Eds), Geologic Excursions In Southern California and Mexico. Guidebook 1991, Geological Society of America, San Diego, California, 1991, 244-271.

Jones, D., \& Mikkelsen, P. (2006). Extended Phase 1 Archaeological Investigations at CA-SLO-1243, 2356 and-2357 and Phase 11 Investigations at CA-SLO-2357, Halcyon Road Climbing Lane Project, Nipomo Mesa, San Luis Obispo County, California. Report prepared for San Luis Obispo County Department of Public Works, San Luis Obispo, California, Project \#P12A172 by Far Western Anthropological Research Group Inc. Davis, California. Retrieved April 17, 2017, from http://www.farwestern.com

Knott, J. R., \& Eley, D. S. (2006). Early to middle Holocene coastal dune and estuarine deposition, Santa Maria Valley, California. Physical Geography, 27, 127-136. https://doi.org/10.2747/0272-3646.27.2.127

Kopp, R. E., Horton, R. M., Little, C. M., Mitrovica, J. X., Oppenheimer, M., Rasmussen, D. J., Strauss, B. H., \& Tebaldi, C. (2014). Probabilistic 21st and 22nd century sea-level projections at a global network of tidegauge sites. Earth's Future, 2, 383-406. https://doi.org/10.1002/2014EF000239

Lettis, W. R., \& Hanson, K. L. (1992). Quaternary tectonic influences on coastal morphology, south-central California. Quaternary International, 15/16, 135-148. https://doi.org/10.1016/1040-6182(92)90042-Z

Masters, P. M. (2006). Holocene sand beaches of southern California: ENSO forcing and coastal processes on millennial scales. Paleogeography, Paleoclimatology, and Paleoecology, 232, 73-95. https://doi.org/10.1016/j.palaeo.2005.08.010

Mengel, M., Levermann, A., Frieler, K., Robinson, A., Marzeion, B., \& Winkelmann, R. (2016). Future sea level rise constrained by observations and long-term commitment. Proceedings of the National Academy of Sciences, 113, 2597-2602. https://doi.org/10.1073/pnas.1500515113

NOAA. (2016). National Data Buoy Center, Station 46054 (LLNR 198) West Santa Barbara, 38 nm west of Santa Barbara, California. National Oceanic and Atmospheric Administration. Retrieved August 1, 2016, from https://ndbc.noaa.gov

NOAA. (2017). National Centers for Environmental Information, National Oceanic and Atmospheric Administration. DEM (LIDAR) Shaded Relief Imagery. Retrieved March 11, 2017, from https://maps.ngdc.noaa.gov/

Orme, A. R. (1992). Late Quaternary deposits near Point Sal, South-Central California: A time frame for coastal dune emplacement. In C.H. Fletcher and J.F. Wehmiller (Eds), Quaternary Coasts of the United States: Marine and Lacustrine Systems, IGCP Project \#274. Society for Sedimentary Geology, Special Publication, 48, 310-315. https://doi.org/10.2110/pec.92.48.0309

Orme, A. R. (1999). Late Quaternary tectonism along the Pacific coast of the Californias: A contrast in style. $\begin{array}{lllll}\text { Geological Society, } & \text { London, } & \text { Special } & \text { Publications, } & 146,\end{array}$ https://doi.org/10.1144/GSL.SP.1999.146.01.10

Orme, A. R., \& Tchakerian, V. P. (1986). Quaternary dunes of the Pacific Coast of Californias. In W.G. Nickling (Ed), Aeolian Geomorphology: London, Alen and Unwin, UK: 149-175. 
Peterson, C. D., Erlandson, J. M., Stock, E., Hostetler, S. W., \& Price, D. M. (2017b). Coastal Eolian Sand Ramp Development Related To Paleo-Sea Level Changes During The Latest Pleistocene and Holocene (21-0 ka) In San Miguel Island, California, USA. Journal of Coastal Research, 33, 1022-1037. https://doi.org/10.2112/JCOASTRES-D-16-00148.1

Peterson, C. D., Grathoff, G. H., Reckendorf, F., Percy, D., \& Price, D. M. (2014). Late Pleistocene coastal loess deposits of the central west coast of North America: Terrestrial facies indicators for marine low-stand intervals. Aeolian Research, 12, 47-64. https://doi.org/10.1016/j.aeolia.2013.11.001

Peterson, C. D., Murillo-Jiménez, M., Stock, E., Price, D. M., Hostetler, S. W., \& Percy, D. (2017a). Origins of late-Pleistocene coastal dune sheets, Magdalena and Guerrero Negro, from continental shelf low-stand supply (70-20 ka), under conditions of southeast littoral- and eolian-sand transport, in Baja California Sur, Mexico. Aeolian Research, 28, 13-28. https://doi.org/10.1016/j.aeolia.2017.07.003

Peterson, C. D., Stock, E., Hart, R., Percy, D., Hostetler, S. W., \& Knott, J. R. (2009). Holocene coastal dune fields used as indicators of net littoral transport: West Coast, USA. Geomorphology, 116, 115-134. https://doi.org/10.1016/j.geomorph.2009.10.013

Peterson, C. D., Stock, E., Meyer, J., Kaijankoski, P., \& Price, D. M. (2015). Origins of Quaternary coastal dune sheets in San Francisco and Monterey Bay, central California Coast, USA: Reflecting contrasts in shelf depocenters and coastal neotectonics. Journal of Coastal Research, 31, 1317-1333. https://doi.org/10.2112/JCOASTRES-D-14-00254.1

Peterson, C. D., Stock, E., Price, D. M., Hart, R., Reckendorf, F., Erlandson, J. M., \& Hostetler, S. W. (2007). Ages, Distributions, and Origins of Upland Coastal Dune Sheets in Oregon, USA. Geomorphology, 91, 8-102. https://doi.org/10.1016/j.geomorph.2007.02.005

Peterson, C., Stock, E., Cloyd, C., Beckstrand, D., Clough, C., Erlandson, J., ... Vanderburgh, S. (2006). Dating and morphostratigraphy of coastal dune sheets from the central west coast of North America. Oregon Sea Grant Publications, Corvallis, Oregon, 81p. PDF on CD.

Reeder-Myers, L., Elandson, J. M., Muhs, D. R., \& Rick, T. C. (2015). Sea level, paleogeography, and archeology on California's Northern Channel Islands. Quaternary Research, 83, 263-272. https://doi.org/10.1016/j.yqres.2015.01.002

Schiedegger, K. F., Kulm, L. D., \& Runge, E. J. (1971). Sediment sources and dispersal patterns of Oregon continental shelf sands. Journal of Sedimentary Petrology, 41, 1112-1120.

Schlocker, J. (1974). Geology of the San Francisco North Quadrangle, California. Geological Survey Professional Paper 782, 109 p. Map scale 1:24,000.

Scott, K. M., \& Williams, R. P. (1978). Erosion and sediment yields in the Transverse Ranges, southern California: U.S. Geological Survey Professional Paper, 1030, 38 p.

Short, A. D. (1987). Modes, timing, and volume of Holocene cross-shore and aeolian sediment transport, Southern Australia. Coastal Sediments, 1987, 1925-1937.

Stillwater Sciences and Kear Groundwater. (2012). Santa Maria River Instream Flow Study: flow recommendations for steelhead passage. Final Report to California Ocean Protection Council, Oakland, California and California Department of Fish and Game, Sacramento, California. 125p. Retrieved January 10, 2017, from http://www.stillwatersci.com/resources/2012SMR_Rec_Report_Final.pdf

Tastet, J. P., \& Pontee, N. I. (1998). Morpho-chronology of coastal dunes in Médoc. A new interpretation of Holocene dunes in Southwestern France. Geomorphology, 25, 93-109. https://doi.org/10.1016/S0169-555X(98)00035-X

Thom, B. G. (1984). Transgressive and regressive stratigraphies of coastal sand barriers in eastern Australia. Marine Geology, 56, 137-158. https://doi.org/10.1016/0025-3227(84)90010-0

Trask, P. D. (1952). Source of beach sand at Santa Barbara, California, as indicated by mineral grain studies. (No. TM-28) Corps of Engineers, Washington DC Beach Erosion Board.

VAFB. (2016). Vandenberg Air Force Base. Geotechnical borehole records database. AFCEC/CZOW EDWARDS IST, RPM. Vandenberg Air Force Base, Vandenberg, California.

VAFB. (2017). Vandenberg Air Force Base. Archaeological site database. AFSPC 30 CES/CEIEA. Vandenberg Air Force Base, Vandenberg, California. 
Woodring, W. P., \& Bramlette, M. N. (1950). Geology and Paleontology of the Santa Maria District, California. U.S. Geological Survey Professional Paper No. 222, Washington, D.C.

Worts, G. F. (1951). Ground-water resources of the Santa Maria Valley Area, California. Geological Survey Water-Supply Paper 1000. United States Department of the Interior, Washington DC., 169p.

Yancey, T. E., \& Lee, J. W. (1972). Major heavy mineral assemblages and heavy mineral provinces of the central California coast region. Geological Society of America Bulletin, 83, 2099-2104. https://doi.org/10.1130/0016-7606(1972)83[2099:MHMAAH]2.0.CO;2

\section{Copyrights}

Copyright for this article is retained by the author(s), with first publication rights granted to the journal.

This is an open-access article distributed under the terms and conditions of the Creative Commons Attribution license (http://creativecommons.org/licenses/by/4.0/). 